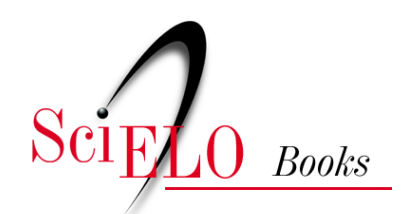

\title{
Dicionário histórico-social do Oeste catarinense
}

\author{
José Carlos Radin \\ Gentil Corazza
}

RADIN, J.C., and CORAZZA, G. Dicionário histórico-social do Oeste catarinense [online]. Chapecó: Editora UFFS, 2018, 142 p. ISBN: 978-85-64905-65-8.

https://doi.org/10.7476/9788564905658.

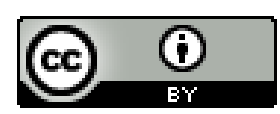

All the contents of this work, except where otherwise noted, is licensed under a Creative Commons Attribution 4.0 International license.

Todo o conteúdo deste trabalho, exceto quando houver ressalva, é publicado sob a licença Creative Commons Atribição 4.0.

Todo el contenido de esta obra, excepto donde se indique lo contrario, está bajo licencia de la licencia $\underline{\text { Creative Commons }}$ Reconocimento 4.0. 


\section{DicIONÁRIO Histó RICO-SOCIAL DO OESTE Catarinense}

José Carlos Radin Gentil Corazza

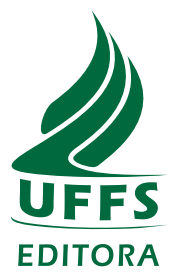




\author{
Reitor Jaime Giolo \\ Vice-Reitor Antônio Inácio Andrioli \\ Chefe do Gabinete do Reitor Stefani Daiana Kruetz \\ Pró-Reitor de Administração e Infraestrutura Péricles Luiz Brustolin \\ Pró-Reitor de Assuntos Estudantis Darlan Christiano Kroth \\ Pró-Reitor de Gestão de Pessoas Marcelo Recktenvald \\ Pró-Reitor de Extensão e Cultura Émerson Neves da Silva \\ Pró-Reitor de Graduação João Alfredo Braida \\ Pró-Reitor de Pesquisa e Pós-Graduação Joviles Vitório Trevisol \\ Pró-Reitor de Planejamento Charles Albino Schutz \\ Secretária Especial de Laboratórios Cladis Juliana Lutinski \\ Secretário Especial de Obras Rodrigo Emmer \\ Secretário Especial de Tecnologia e Informação Claunir Pavan \\ Procurador-Chefe em exercício Douglas Alexandre Goergen \\ Diretor do Campus Cerro Largo Ivann Carlos Lago \\ Diretora do Campus Chapecó Lísia Regina Ferreira Michels \\ Diretor do Campus Erechim Anderson André Genro Alves Ribeiro \\ Diretora do Campus Laranjeiras do Sul Janete Stoffel \\ Diretor do Campus Passo Fundo Vanderlei de Oliveira Farias \\ Diretor do Campus Realeza Antônio Marcos Myskiw
}




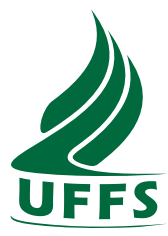

EDITORA

Diretor da Editora UFFS

\section{Valdir Prigol}

Chefe do Departamento de Publicações Editoriais

Fabiane Pedroso da Silva Sulsbach

Revisora de texto

Marlei Maria Diedrich

Secretária Executiva

Claudiane Brito de Almeida

\section{Conselho Editorial}

Marlon Brandt (Presidente)

Tiago Vecchi Ricci

Gilmar Roberto Meinerz

Demétrio Alvez Paz

Paulo Afonso Hartmann

Bernardo Berenchtein

Thiago Bergles Bitencourt

Gustavo Acrani

Vanderleia Laodete Pulga

Adelita Maria Linzmeier

Rozane Marcia Triches

Antonio Marcos Myskiw

Valdir Prigol

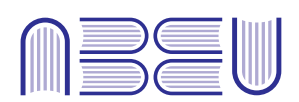

Associação Brasileira das Editoras Universitárias 


\author{
REVISÃO Marlei Maria Diedrich \\ PROJETO GRÁFICO E Mariah Carraro Smaniotto \\ DIAGRAMAÇÃO \\ CAPA Felipe Stanque Machado Junior
}

DIVULGAÇÃO Diretoria de Comunicação

FORMATO DO E-BOOK ePub, mobi e PDF

R124d Radin, José Carlos

Dicionário histórico-social do Oeste catarinense / José Carlos, Gentil Corazza. - Chapecó : Ed. Universidade Federal Fronteira Sul, 2018. -

145 p. : il..

ISBN: 978-85-64905-66-5 (Mobi).

ISBN: 978-85-64905-65-8 (e-pub).

ISBN: 978-85-64905-64-1 (pdf).

1. História - Santa Catarina - Região Oeste - Dicionários 2.

História social - Santa Catarina - Região Oeste - Dicionários. I.

Título. II. Corazza, Gentil.

CDD: 981.64

Ficha catalográfica elaborada pela

Divisão de Bibliotecas - UFFS

Nelcy T. da Rosa Kegler

CRB - 14/1311 


\section{Sumário}

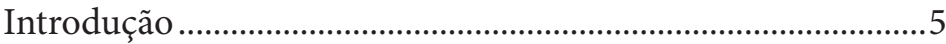

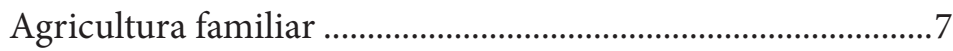

Agroindústria familiar ...............................................................11

Agroindústria frigorífica ...............................................................16

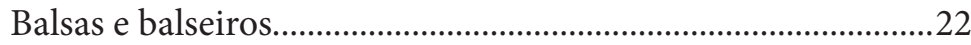

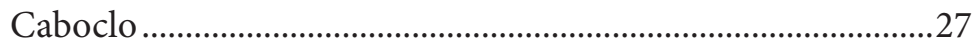

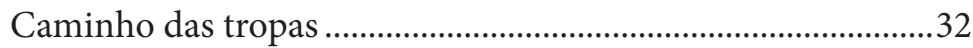

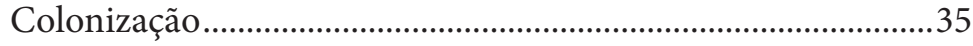

Cooperativismo ...................................................................................4

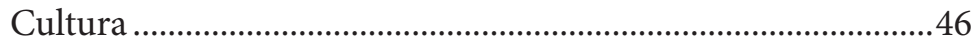

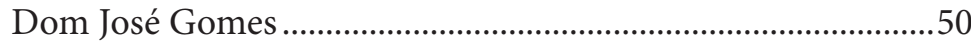

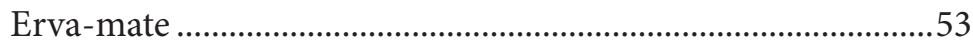

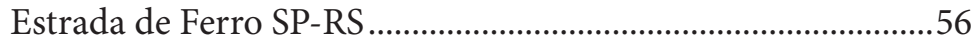

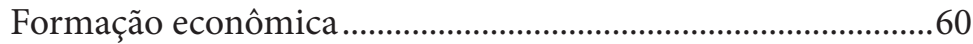

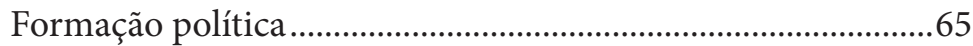

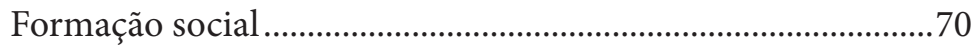

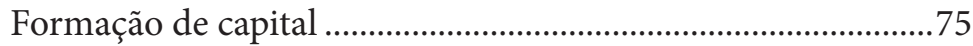

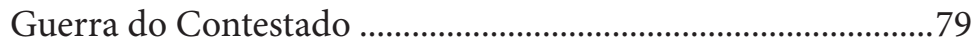

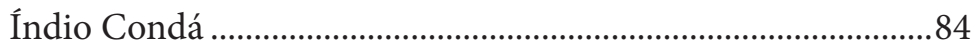

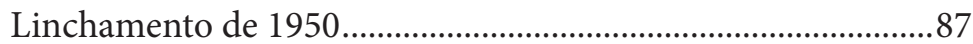

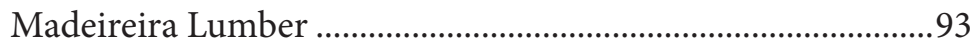

Modelo de desenvolvimento ..........................................................97

Movimento das Mulheres Camponesas (MMC).........................102

Movimento dos Atingidos por Barragens (MAB)......................105 
Movimento dos Pequenos Agricultores (MPA) ..........................108

Movimento dos Trabalhadores Rurais Sem Terra (MST) .........110

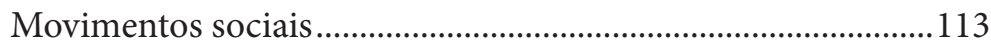

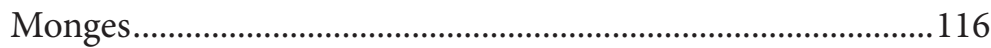

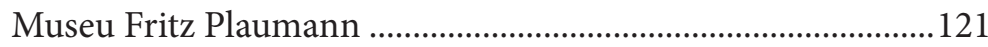

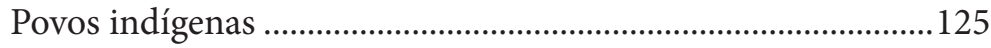

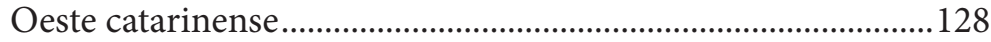

Questão interestadual de limites: SC-PR.....................................132

Questão de Palmas ......................................................................135

Território Federal do Iguaçu ..........................................................138

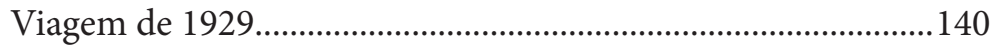




\section{Introdução}

Este Dicionário histórico-social contém pequenos ensaios sobre temas relevantes do Oeste de Santa Catarina. Entre tais temas, destacam-se a história, a sociedade, a economia, a política e a cultura, além de outros assuntos relacionados a estes grandes temas. A escolha temática não foi aleatória, mas feita a partir de estudos anteriores, que ressaltam sua importância para compreender a região em análise. Também não são temas isolados uns dos outros, mas estreitamente relacionados e, algumas vezes, até parcialmente repetidos e superpostos uns aos outros. Preferiu-se incorrer nesse tipo de problema a deixar de abordar tais aspectos, que se mostram essenciais para a compreensão de cada tema. Julgou-se preferível, portanto, a superposição de temas e de análises a deixar lacunas entre eles, pois isso certamente limitaria a abrangência e a qualidade do trabalho. Do ponto de vista temporal, abordam-se questões históricas que envolveram personagens e questões relevantes desta região durante um longo período, que vai principalmente do final do século XIX até a atualidade. Os verbetes foram produzidos a partir de trabalhos existentes, bem como de outras fontes. Em futuras ampliações e atualizações deste Dicionário, pretende-se que eles sejam ilustrados, em especial com fotografias.

Pode-se perguntar, também, por que apresentar a análise desses temas na forma de um dicionário de pequenos ensaios e não como estudos mais longos e aprofundados? Duas razões nos levaram a optar pelo formato de dicionário. Em primeiro lugar, porque praticamente todos os temas, aqui apresentados como pequenos ensaios, já foram objeto de inúmeros estudos mais longos e aprofundados, na forma de artigos, livros e trabalhos acadêmicos, os quais compõem uma ampla bibliografia sobre a história e a sociedade desta região. Uma segunda razão que motivou a apresentação dos estudos na forma de um dicionário, não de definições, mas de verbetes ou pequenos ensaios, se expressa na própria natureza e no objetivo de um dicionário, que é servir de introdução e guia para outros estudos de maior envergadura, sempre necessários para alargar e aprofundar a compreensão dos temas 
abordados. Dessa forma, um dicionário não pretende substituir esses estudos, mas sim estimulá-los.

É nesse sentido, também, que este Dicionário não é apresentado como uma obra acabada e sim de um trabalho introdutório, em construção, que possa motivar estudantes e pesquisadores interessados em aprofundar seus conhecimentos sobre os temas analisados. Este Dicionário histórico-social é uma obra aberta a contribuições de novos autores que se disponham a elaborar outros ensaios de sua especialidade,os quais possam enriquecer este trabalho introdutório. São bem-vindas também as críticas e sugestões que contribuam para aprofundá-lo e melhorá-lo. Nessa perspectiva, pretende-se que ele seja periodicamente revisado e ampliado, especialmente pela inclusão de novos temas/verbetes.

Boa leitura! 


\section{Agricultura familiar}

A agricultura familiar é constituída por pequenas unidades produtivas rurais, em que os agricultores podem ser tanto proprietários da terra e dos meios de trabalho como parceiros ou meeiros, dependendo da região, mas a mão de obra e a gestão das atividades são familiares. A maior parte da produção destina-se à subsistência da família e apenas o excedente é comercializado. Em determinadas épocas do ano, quando possuem tempo livre, esses agricultores também podem realizar trabalho fora da unidade familiar, buscando complementar a renda da família. A agricultura familiar possui sua própria lógica interna de desenvolvimento.

Além disso, as unidades produtivas familiares caracterizam-se por uma autonomia relativa em face aos mercados em que comercializam parte de sua produção, embora mantenham relações estruturais com o sistema econômico dominante do qual fazem parte. Historicamente a agricultura familiar construiu uma lógica interna de desenvolvimento própria, uma vez que se destina fundamentalmente a produzir valores de uso, para o próprio consumo, e só comercializa a produção excedente, mas, à medida que se estreitam suas relações com os mercados, essa lógica vai sofrendo transformações e se subordinando progressivamente à lógica do capitalismo industrial em que está inserida, mesmo que de forma parcial e indireta. Esse processo se intensifica, no Brasil, sobretudo a partir da segunda metade do século XX, com a modernização da agricultura empresarial. Por isso, a agricultura familiar costuma ser vista não apenas como uma forma particular de produção, mas também como um modo de vida, ainda que ocupando uma posição subordinada, tanto econômica como politicamente, diante de uma sociedade preponderantemente urbana, em que se insere cada vez mais.

Por tais características e pelo papel especial que desempenha no sistema capitalista, a agricultura familiar constituiu-se, ao longo da história, em objeto de um intenso debate, entre visões teóricas diferentes sobre a posição especial que ocupa na evolução e no contexto 
do desenvolvimento econômico de um país. A tradição marxista, baseada fundamentalmente nas posições de Lênin e Kautsky, apontava para a tendência ao desaparecimento gradual da agricultura familiar no curso do desenvolvimento capitalista, pois, num sistema capitalista, que se caracteriza pela separação entre os proprietários dos meios de produção e os trabalhadores diretos, o agricultor familiar figura como algo "anacrônico", uma vez que o próprio agricultor permanece, ao mesmo tempo, como proprietário da terra e dos meios de produção e como trabalhador direto na produção agrícola. Nesse sentido, a agricultura familiar, em si mesma, não se caracteriza como uma organização econômica capitalista, pois não emprega mão de obra assalariada e os trabalhadores diretos continuam sendo proprietários da terra e dos meios de produção.

Assim, de acordo com a perspectiva teórica desses autores, a lógica do desenvolvimento capitalista deveria transformar os agricultores familiares em duas novas categorias típicas do modo de produção capitalista: os agricultores mais fortes, e em melhores condições econômicas, seriam transformados em futuros capitalistas agrícolas e os pequenos seriam transformados em operários agrícolas. No entanto, esta previsão teórica só foi confirmada parcialmente pela história posterior do capitalismo, pois, mesmo nos países mais desenvolvidos, a agricultura familiar, além de não ter desaparecido, foi capaz, ainda, de reestruturar-se, para sobreviver e poder reproduzir-se, e, inclusive, em muitos casos, tornou-se um segmento importante na produção de alimentos para o mercado capitalista.

Outros autores, no entanto, ressaltam que a permanência da agricultura familiar, no contexto da economia capitalista, se deve as suas próprias especificidades e a sua natureza de produção simples de mercadorias, que a habilitam a articular-se, de diferentes maneiras, com a produção capitalista. Em muitos casos, a produção familiar pode, inclusive, tornar-se funcional para a produção capitalista, na medida em que produz alimentos mais baratos para os trabalhadores assalariados, agrícolas ou urbanos, contribuindo para o barateamento dos custos de produção, bem como de alimentos mais saudáveis. Análises desse tipo parecem trazer uma grande contribuição para o entendimento da 
agricultura familiar, ao colocá-la dentro do sistema capitalista, explicitando suas diversas formas de articulação, e não pensá-la à margem ou em oposição ao modo de produção capitalista.

No Oeste catarinense, a peculiar articulação da agricultura familiar com a indústria frigorífica representa um caso particularmente relevante, no contexto teórico mencionado. Ou seja, a relevância da agricultura familiar persiste e se desenvolve, tanto em nível de Brasil como regional. No Brasil, dados do IBGE indicam que, em 2009, dos 5.175.000 estabelecimentos agrícolas do país, 84,4\% eram familiares, ocupavam $24,3 \%$ da área cultivada total, representavam $74,4 \%$ das pessoas ocupadas e eram responsáveis por 38\% do Valor Bruto da Produção agrícola.

Apesar dessa importância, ao menos numérica, que a agricultura familiar representa, o seu debate, no Brasil,é relativamente recente, mas ganhou força a partir do final dos anos 1980 e início dos anos 1990, quando a organização dos pequenos produtores familiares e os movimentos sociais levaram a discussão para o âmbito acadêmico e político, procurando discutir sobre o espaço e o papel dos pequenos produtores rurais no desenvolvimento da agricultura nacional.

Nas décadas de 1970 e 1980, as políticas públicas do Estado brasileiro praticamente ignoraram a questão dos pequenos agricultores, pois a orientação política pretendia apoiar o processo conhecido como "modernização conservadora" da agricultura, embora houvesse toda uma discussão sobre a funcionalidade da agricultura para o desenvolvimento urbano industrial do país. De fato, a legitimação da agricultura familiar perante o Estado só veio a ocorrer em meados dos anos 1990, especialmente com os dados do Censo Agropecuário de 1996. A criação de uma política específica para este segmento da agricultura brasileira, o Programa Nacional de Fortalecimento da Agricultura Familiar (PRONAF), representa uma forma de legitimação da agricultura familiar no Brasil, como já vinha sendo feito na maioria dos países desenvolvidos.

Essa discussão mostrou, entre outras coisas, que além de não ter ocorrido a anunciada decomposição do campesinato brasileiro, como se apregoava, a agricultura familiar, enquanto forma social de 
produção, ainda ocupa um lugar importante no cenário atual da economia e da sociedade brasileiras.

No Oeste catarinense, a agricultura familiar assume características próprias. A estrutura agrária é formada de pequenas áreas, onde cerca de $95 \%$ das propriedades têm menos de 50 hectares e 70 $\%$ delas têm menos de 20 hectares. Cerca de $50 \%$ da população economicamente ativa da região trabalha em atividades agropecuárias. O desenvolvimento da agricultura familiar, nesta região, desde muito cedo, esteve atrelado ao desenvolvimento da agroindústria frigorífica.

\section{REFERÊNCIAS}

COLETTI, Tomé; LINS, Hoyêdo Nunes.A suinocultura no vértice das relações entre agroindústria e agricultura familiar no Oeste de Santa Catarina. Porto Alegre: Ensaios FEE, v. 32, n. 2, p. 339-360, nov. 2011. MIOR, Luiz Carlos. Agricultores familiares, agroindústrias e redes de desenvolvimento rural. Chapecó: Argos, 2005.

NIEDERLE, Sidnei Luiz; KOCK EXTERKOTER, Rudinei. Formação e Desenvolvimento da Agricultura Familiar no Oeste Catarinense: buscando novos caminhos. XXI Encontro Nacional de Geografia Agrária. Uberlândia, 2012.

PLEIN, Clério. A Formação da Agricultura Familiar no Oeste de Santa Catarina: o caso das colônias Porto Feliz e Porto Novo. Revista Faz

Ciência, Unioeste, Cascavel, vol. 07, n. 01, 2005, p. 79-102. 
A agroindústria familiar é definida como um empreendimento rural, de pequeno porte, que utiliza métodos artesanais de produção, usa sua própria matéria-prima e emprega mão de obra familiar, para produzir, processar ou transformar parte de sua produção, com objetivo de agregar valor e vender seus produtos para o mercado. Uma parte de sua produção, contudo, destina-se ao próprio consumo da família. $\mathrm{Na}$ sua origem, a agroindústria familiar pode ser entendida como uma diversificação produtiva dentro da agricultura familiar. Embora esse tipo de atividade tenha recebido várias denominações, como agroindústria rural, agroindústria de pequeno porte, agroindústria artesanal ou agroindústria colonial, a denominação mais consagrada foi a de agroindústria familiar. Em geral, essas organizações são de caráter individual ou familiar, mas há também agroindústrias societárias, geralmente com pequeno número de sócios.

Essas atividades se alimentam de saberes e práticas cotidianas tradicionais da agricultura familiar. Parece claro que os colonos sempre souberam processar alimentos para seu autoconsumo, pois foi a partir desse ofício que se desenvolveram as novas agroindústrias familiares na região. As atividades da agroindústria familiar alimentam-se de saberes e práticas cotidianas tradicionais da agricultura familiar. Trata-se de um saber fazer, de um capital cultural transmitido de geração para geração. Foi justamente este capital cultural que deu o suporte para o desenvolvimento das novas agroindústrias familiares na região. Mas não se trata de simples repetição das mesmas atividades de processar alimentos, prática que os agricultores sempre fizeram, pois agora, no âmbito da agroindústria familiar, o processamento de alimentos ganha um conteúdo comercial. Há uma mudança na própria natureza da produção de alimentos, quando seu novo objetivo passa a ser a agregação de valor aos mesmos produtos. Muda-se o objetivo, que era produzir valores de uso para o consumo, para a produção de valores de troca para o mercado. 
Nesse sentido, a formação das agroindústrias familiares não é a repetição das atividades tradicionais de agricultores. Trata-se de uma reconversão da agricultura familiar e não simplesmente de uma volta ao passado; um verdadeiro passo à frente. Transformar um produto caseiro de consumo familiar em produto comercial - valor de uso em valor de troca - significa uma forma de reinventar atividades antigas e tradicionais, uma nova forma de reinserção econômica e social dos pequenos agricultores familiares.

As iniciativas para formar novas agroindústrias familiares, no entanto, não surgem do acaso, mas resultam de uma longa tradição cultivada pelos agricultores, desde os tempos da colonização, que tem por base, além das relações de parentesco e de boa vizinhança, uma cultura de sociabilidade, solidariedade, religiosidade e confiança mútua entre as famílias de agricultores, pois sempre foram muito comuns, no meio rural, a troca de dias de serviço, o mutirão, os trabalhos coletivos nas lavouras e, dentre outras ações coletivas, a ajuda mútua na construção de equipamentos coletivos, como igrejas, escolas e salões comunitários.

O tema da agroindústria familiar rural e do processamento dos produtos agrícolas pelos próprios agricultores ficou longo tempo fora do debate e só foi retomado ao longo da década de 1980. Essa retomada das discussões sobre a agroindustrialização familiar passou a ganhar força principalmente com as dificuldades pelas quais passaram as atividades exclusivamente agrícolas enquanto fonte de renda das famílias rurais e as reconfigurações dos mercados agroalimentares. Ao mesmo tempo, essas atividades foram reconhecidas como importantes e passaram a merecer a atenção de um crescente número de programas governamentais de incentivo ao desenvolvimento das agroindústrias familiares.

De modo geral, o contexto mais amplo em que surgiram as novas agroindústrias familiares foi o processo de modernização pelo qual passou todo o sistema agroalimentar brasileiro, que afetou profundamente os pequenos agricultores familiares. No Oeste catarinense, também, a reestruturação do complexo agroindustrial tradicional, a partir dos anos 1980, implicou a exclusão de dezenas de milhares de pequenos agricultores integrados à indústria frigorífica de suínos 
e aves, gerando uma crise não apenas na agricultura, mas em toda a economia regional, dada a importância que tem a agricultura familiar na economia da região, especialmente em relação ao emprego da mão de obra agrícola.

Foi neste contexto de crise da pequena produção agrícola do Oeste catarinense que começaram a estruturar-se as novas agroindústrias familiares, como uma reação à própria situação de crise da agricultura familiar. Das quase duas mil agroindústrias familiares de Santa Catarina, cerca de 500 estão localizadas no Oeste e Extremo Oeste catarinense, o que evidencia a significativa concentração dessas atividades na região. Outro fator que serviu de estímulo ao ressurgimento das agroindústrias familiares foi a intensificação do processo de industrialização e globalização da produção de alimentos, que aumentou a desconfiança e a incerteza dos consumidores sobre a origem e a qualidade dos alimentos que consumiam. Passou-se a demandar alimentos mais saudáveis, com origem conhecida, com menores riscos à saúde e ao meio ambiente e, assim, começaram a ser valorizados produtos orgânicos, com denominação de origem e da agricultura familiar, associados à tradição, à natureza, ao fazer artesanal e aos mercados locais.

As agroindústrias familiares são estimuladas pela proximidade entre os produtores e os consumidores, o que, além de implicar a redução de custos, confere aos consumidores uma maior confiança sobre os produtos, por conhecerem sua procedência. Muitas vezes, entretanto, se desconhecem as condições sanitárias em que são produzidos, em razão da inexistência de fiscalização. Por outro lado, tem sido crescente a presença das feiras no meio urbano com uma expressiva participação das agroindústrias nesses espaços. Processa-se, assim, uma espécie de redescoberta do mercado local pelos agricultores familiares.

As novas agroindústrias familiares do Oeste catarinense apresentam duas características básicas: primeira, não são atividades monocultoras, pois abrangem o cultivo e processamento de vários produtos; segunda, um elevado percentual delas é dirigido por mulheres, cujo papel se destaca também na comercialização dos produtos, feita no mercado local, num comércio caracterizado por relações diretas, tanto com os consumidores, quanto com os pequenos varejistas. 
Trata-se de agroindústrias que se dedicam ao cultivo e processamento de vários produtos, cuja comercialização é feita no mercado local, num comércio caracterizado por relações diretas, tanto com os consumidores, quanto com os pequenos varejistas. É significativo, também, o número de agroindústrias familiares que vendem para o mercado institucional, como a alimentação escolar e o Programa de Aquisição de Alimentos. No entanto, preponderam as vendas diretas ao consumidor, pois, na maior parte dos casos, o consumidor compra diretamente no próprio empreendimento ou o empreendedor faz a entrega do produto no domicílio do cliente consumidor. Esses empreendimentos familiares carecem de assistência técnica e assessoramento em relação a vários pontos, como as relações de mercado com seus clientes, as formas de controle geral e, sobretudo, o controle de qualidade dos produtos, o planejamento financeiro e a gestão das atividades como um todo. A maioria dessas organizações já ultrapassou o período crítico de sobrevivência, que, de modo geral, afeta as pequenas empresas de outros setores de atividades. Observa-se, ainda, um elevado grau de informalidade de muitas dessas organizações ainda não cadastradas como pessoas jurídicas e um deficiente controle sanitário sobre muitos de seus produtos, sobretudo os de origem animal. A correção desses problemas parece fundamental para a sobrevivência e para o bom desempenho dessas organizações familiares.

Uma avaliação preliminar indica que os resultados dessas novas atividades, em geral, são positivos, especialmente em termos de geração de renda complementar e de emprego agrícola. No entanto, parece prematuro e exagerado esperar que tais atividades possam constituir o embrião de mudanças qualitativas no modelo de desenvolvimento agrícola da região. Sem negar sua importância real para o conjunto de agricultores nelas envolvidos, o que parece estar em questão não é tanto a agricultura familiar e o desenvolvimento regional, mas a reprodução social de um importante contingente de agricultores familiares. Trata-se, sobretudo, de uma questão de emprego, sobrevivência e reprodução dessas famílias mais do que da estruturação de um novo modelo de desenvolvimento regional do Oeste catarinense. Sua natureza, seu alcance e seus limites definem-se no contexto maior de uma 
economia capitalista nacional e regional concentrada em grandes empresas agroindustriais que atuam em mercados fortemente globalizados.

\section{REFERÊNCIAS}

MIOR, Luiz Carlos. Agricultores familiares, agroindústrias e redes de desenvolvimento rural. Chapecó: Argos, 2005.

MELLO, Márcio Antônio de; SCHNEIDER, Sérgio. A Produção de "novidades" como alternativa à crise pelos agricultores do Oeste de Santa Catarina. Desafio Online: Campo Grande, v. 1, n. 3, set./dez. 2013. RENK, Arlene. Sociodiceia às avessas. Chapecó: Grifos, 2006. 


\section{Agroindústria frigorífica}

A agroindústria frigorífica é um ramo da indústria relacionado às atividades de produção, transformação e comercialização de produtos agropecuários, alimentares e não alimentares. O grau de transformação desses produtos pode variar de acordo com cada uma das empresas agroindustriais. De modo geral, as atividades da agropecuária costumam estar subordinadas ao processo de industrialização, pois são fornecedoras de insumos para as atividades da indústria de transformação às quais estão ligadas.

No Oeste catarinense, a agroindústria frigorífica incorporou as características gerais do modelo agroindustrial, mas assumiu também características próprias associadas a sua formação histórica e ao desenvolvimento regional. A principal característica deste ramo agroindustrial no Oeste catarinense foi a articulação entre o frigorífico e a agricultura familiar no processo de transformação de carnes de suínos e de aves. Como regra geral, pode-se afirmar que os primeiros frigoríficos da região se formaram a partir de pequenos abatedouros, alimentados pela criação de suínos feita pelos próprios colonos agricultores e pelo capital comercial acumulado pelos pequenos comerciantes. Evidentemente, não há base para afirmar que todos os pequenos abatedouros se transformaram em pequenos frigoríficos, nem que todos os frigoríficos resultaram da evolução dos pequenos abatedouros, pois muitos deles podem ter surgido de outra forma. O que se indica aqui é o modelo geral da origem e evolução das atividades e das organizações agroindustriais, desde os pequenos abatedouros, passando pelos pequenos frigoríficos até assumirem a forma do complexo agroindustrial frigorífico atual.

Sabe-se que, em 1939, já funcionava, em Xaxim, o frigorífico Diadema, com cerca de 50 empregados. Depois, surgiram vários outros, mais ou menos na seguinte ordem cronológica: Perdigão, em 1940, no município de Videira; Saulle Pagnoncelli, em 1942, em Joaçaba; Sadia, em 1944, em Concórdia; SAIC, SA Indústria e Comércio Chapecó, em 1952, e a Indústria e Comércio Marafon Ltda, em 1956, ambas na cidade de Chapecó; Frigorífico Seara, também no ano de 1956, em 
Seara; Frigorífico Itapiranga, em 1962, em Itapiranga;Frigorífico Unifrico, em 1963, em Salto Veloso; Indústrias Reunidas Ouro, na década de 1960, no município de Ouro; Cooperativa Central Oeste catarinense, em 1969, em Chapecó; e, por fim, o Frigorífico São Carlos, Friscar, em 1975, no município de São Carlos.

De início, a principal atividade frigorífica era a produção de banha, salame e linguiça, tendo em vista as limitações da indústria, por falta de energia elétrica. A importância da banha, inclusive para a conservação da carne, valorizava os suínos tipo banha. A situação começa a mudar com a instalação de câmeras frias, em virtude de melhorias no fornecimento da energia elétrica e das condições de transporte.

Até a década de 1950, a capacidade produtiva dos frigoríficos dependia da capacidade de produção familiar de suínos. A influência das indústrias sobre a produção de suínos era tênue e indireta. Então, para não depender apenas da oferta de matéria-prima feita pelos agricultores, os frigoríficos começaram a interferir na produção familiar de suínos, oferecendo matrizes e rações de melhor qualidade. Começava aí o processo de integração da agricultura familiar com a indústria frigorífica, um primeiro passo importante para o desenvolvimento da agroindústria de carnes. $\mathrm{O}$ aperfeiçoamento e a consolidação do modelo de integração, entre o frigorífico e a criação familiar de suínos, foi dado pela Sadia, no início dos anos 1960, através da implementação de seu Departamento de Fomento Agropecuário, que deu um grande impulso tanto para as atividades frigoríficas como para a criação de suínos. A melhoria na produção de suínos provocada pela Sadia se deu inicialmente em sua própria granja e, mais tarde, através de acordos verbais com alguns colonos, a quem a Sadia fornecia matrizes selecionadas, para serem pagas, depois, com a venda da produção. A integração entre os agricultores familiares e os frigoríficos suínos foi, portanto, uma iniciativa da indústria frigorífica. A motivação principal da integração reside na necessidade de os frigoríficos garantirem uma contínua oferta de produtos homogêneos e de boa qualidade por parte dos agricultores. Estes, por sua vez, ganhavam com a garantia da compra de sua produção por parte do frigorífico. No início, os produtores agrícolas continuavam produzindo para sua subsistência e para o 
mercado, mas a integração com os frigoríficos foi exigindo-lhes uma especialização crescente, até o ponto em que a produção de subsistência se tornasse uma atividade secundária e o pequeno produtor agrícola passasse a produzir exclusivamente para os frigoríficos.

O sistema de integração representa uma etapa decisiva na evolução e aperfeiçoamento da criação e comercialização de suínos, se considerarmos as etapas anteriores de uma produção rústica e tradicional, com animais, tipo banha, criados soltos e a criação em chiqueirões, com novas raças importadas de animais tipo carne, como as raças Duroc, Landrace e Large White. O processo de integração avançou lenta e gradativamente. No seu início, a integração entre os pequenos produtores de suínos e os frigoríficos era baseada em acordos verbais informais, mas, aos poucos, ela foi se formalizando e aperfeiçoando através de contratos, que estabeleciam uma relação de compra e venda garantida dos suínos, em que os preços e as condições de pagamentos eram pré-fixados, sem, contudo, interferir nas condições e formas de produção. Os primeiros contratos baseavam-se nos princípios da cooperação e proteção mútuas e atendiam aos objetivos tanto dos agricultores como dos frigoríficos. Depois, foi ocorrendo um estreitamento dos laços entre produtores e frigoríficos, através de um verdadeiro contrato de integração, que envolvia não apenas preços e condições de pagamento, mas interferia, também, na maneira de produzir das unidades rurais, com fornecimento de assistência técnica, rações e transporte da produção. Nesses contratos, os produtores se comprometem a cumprir rigorosamente um conjunto de normas técnicas estabelecidas pelas empresas, que incluem desde as instalações e os cuidados com os animais, bem como a entrega dos animais prontos para abate, em prazos preestabelecidos pelos frigoríficos. Além disso, os agricultores se comprometem a oferecer a mão de obra necessária para a produção e a arcar com os encargos sociais. A dificuldade para cumprir tais exigências contribui para a gradativa exclusão dos agricultores do sistema de integração e a gradativa concentração dessa atividade em propriedades mais estruturadas.

Para os agricultores, a integração com a indústria frigorífica garante o escoamento de toda a produção, além de maior facilidade ao crédito. Para as agroindústrias, a integração garante matéria-prima de 
qualidade a um custo menor, já que elas não necessitam investir em instalações, terras e mão de obra, tendo em vista que as agroindústrias frigoríficas se responsabilizam pela assistência técnica, além de financiar os investimentos necessários. Como resultado, a integração implica, também, uma produção de melhor qualidade, melhorias nas instalações físicas e novas técnicas produtivas, que potencializam a pequena propriedade rural.

Depois do processo inicial de integração, em suas fases informal e formal, dos anos 1960 e 1970, um novo padrão de integração tornou-se dominante na região Oeste catarinense, na década de 1980, o qual passou a ser chamado de modelo de integração de ciclo completo. Nesse modelo de integração, os agricultores tinham o controle e o comando do processo de produção, que se baseava muito mais no conhecimento, na capacidade produtiva e na organização da produção feita pelos próprios agricultores, mas incluía também a introdução de novas técnicas produtivas, novas raças de suínos e novas estruturas de produção. No entanto, este modelo de integração de ciclo completo foi perdendo força ainda nos anos 1980, sendo gradativamente substituído pelo modelo de parceria, que se tornou dominante a partir dos anos 2000. No sistema de parceria, as responsabilidades de cada uma das partes ficam claramente estabelecidas: os agricultores entram com as instalações, os equipamentos e a mão de obra e as agroindústrias frigoríficas fornecem os animais, os insumos, os medicamentos e a assistência técnica. A remuneração que os agricultores recebem depende de sua produtividade, mas os critérios de cálculo da produtividade são definidos pelas empresas e não são conhecidos pelos próprios agricultores.

Em meados da década de 1970, a agroindústria frigorífica passou a incorporar a avicultura em suas atividades. Uma das razões para a expansão das atividades frigoríficas em direção à avicultura foi a existência de um excedente de capital acumulado na produção frigorífica de carnes suínas, que buscava uma aplicação mais rentável e encontrou na avicultura um destino produtivo. Em contraste com a integração de suínos, que foi considerado um processo lento, ao menos no seu início, a integração da criação de aves foi submetida às exigências mais modernas 
do complexo agroindustrial. Assim, a integração do complexo avícola incluía a exigência de estruturas mínimas para a criação de aves, o fornecimento dos pintinhos, as rações adequadas e a assistência técnica especializada por parte das agroindústrias. Todas as despesas decorrentes de tais serviços são descontadas da remuneração no momento do abate dos frangos. Mesmo exigindo investimentos iniciais altos, a avicultura oferece resultados maiores e mais rápidos que a suinocultura. Talvez este seja um dos motivos, dentre outros, da rápida expansão da avicultura e de sua afirmação como principal atividade agroindustrial da região.

Esse complexo agroindustrial regional de suínos e aves, marcado pela peculiar integração da indústria frigorífica com a agricultura familiar, formado nos anos 1940 e 1950, torna-se maduro e se consolida nas décadas de 1970 e de 1980, vindo a transformar-se em pilar do modelo de desenvolvimento econômico regional. Além de uma rápida expansão dos níveis de produção, o complexo da agroindústria frigorífica regional de suínos e aves inclui a completa verticalização das atividades e uma grande concentração de capital com a incorporação de várias empresas, formando os grandes oligopólios que hoje dominam a indústria frigorífica do Oeste catarinense.

O sistema de integração, embora tenha alterado o modo de vida colonial, inserindo novas formas de relações de produção e um novo ambiente social e econômico, significou um avanço na produção familiar e uma melhoria nas condições de vida dos agricultores integrados. Apesar de subordinados ao capital industrial, os agricultores ainda continuam proprietários de suas terras e de seus meios de produção. Mas, por outro lado, a integração implicou, também, grandes perdas para os agricultores familiares, sobretudo em relação a sua autonomia e ao controle sobre sua produção. Somando ganhos e perdas, eles melhoraram sua condição de vida e souberam se adaptar ao novo sistema de produção e ao novo modo de vida. Aparentemente, conservam ainda muitos elementos de seu antigo modo de vida de colonos e de agricultores familiares, mas na realidade efetiva se tornaram trabalhadores subordinados às agroindústrias, sem salário fixo e sem qualquer dos direitos trabalhistas assegurados aos outros trabalhadores. 
Resumindo, numa perspectiva histórica de longo prazo, podem-se distinguir pelo menos duas grandes fases do desenvolvimento da agroindústria frigorífica da região (COLETTI, 2009). A primeira, que vai de seu início, na década de 1950, até o final da década de 1980, caracteriza-se pelo continuado processo de integração de um número crescente de agricultores no setor agroindustrial. O destino da produção era principalmente o mercado interno brasileiro e havia maior convergência de interesses entre frigoríficos e agricultores integrados. A segunda fase inicia no final da década de 1980 e início da década de 1990 e se estende aos dias atuais. Essa fase se caracterizou pelo processo de profunda reestruturação produtiva, tecnológica e organizacional do complexo agroindustrial frigorífico do Oeste catarinense e teve como consequência maior a exclusão de grande número de agricultores, rompendo a convergência de interesses da fase anterior e provocando um grande conflito no processo de integração. Essa reestruturação, ao afetar profundamente $o$ modelo de integração, acabou por afetar, em alguma medida, o modelo de desenvolvimento regional, cada vez mais comandado pelas grandes empresas do setor de carnes e derivados do Brasil, que formam o maior complexo agroindustrial frigorífico da América Latina.

\section{REFERÊNCIAS}

COLETTI, Tomé; LINS, Hoyêdo Nunes.A suinocultura no vértice das relações entre agroindústria e agricultura familiar no oeste de Santa Catarina. Porto Alegre, Ensaios FEE, v. 32, n. 2, p. 339-360, nov. 2011. COLETTI, Tomé. Agroindústria suinícola e agricultura familiar: uma "crônica" sobre a trajetória histórica no Oeste Catarinense. Florianópolis, UFSC, Dissertação de Mestrado, 2009.

KROTH, Darlan Christiano. A Agroindústria do Oeste Catarinense e o Desenvolvimento Regional sustentável: os velhos e os novos desafios no novo século. In: Corazza e Radin. Fronteira Sul: ensaios socioeconômicos. Florianópolis: Insular, 2016.

MIOR, Luiz Carlos. Agricultores familiares, agroindústrias e redes de desenvolvimento rural. Chapecó: Argos, 2005. 


\section{Balsas e balseiros}

As balsas eram composições de madeira, aglomerados de troncos, toras ou tábuas serradas, armadas para transportar as madeiras oriundas do Oeste catarinense, através do rio Uruguai, até o principal porto de destino, que era São Borja, no Rio Grande do Sul, de onde eram rebocadas ao Rio da Prata, para depois serem exportadas. Para a armação das balsas as madeiras eram arrastadas ou levadas em carroças ou caminhões, até a barranca do rio Uruguai e de seus afluentes, de acordo com a previsão de cheias do rio Uruguai. Os balseiros eram os trabalhadores, caboclos e agricultores que montavam as balsas e as conduziam até os portos de destino, com o objetivo de ganhar uma renda extra, num trabalho sazonal, nos períodos das cheias.

As atividades das balsas e dos balseiros abrangeram um período de aproximadamente 30 anos, basicamente entre 1930-1960. Iniciado na década de 1930, o ciclo da madeira já representava mais de vinte por cento do valor total das exportações do Estado de Santa Catarina, na década de 1940, chegando a cinquenta por cento de todo o volume exportado no período entre 1950 e 1960 . Tais atividades se inseriam no contexto socioeconômico da região no período mais intenso de extração da madeira, em que as estradas e os meios de transporte eram muito precários. Nessas circunstâncias, por oferecerem condições de navegabilidade nos períodos de cheias, o rio Uruguai e seus afluentes, que permeiam parte do território do Oeste catarinense, mostravam-se como uma solução para o escoamento das madeiras da região.

Os principais locais de partida das balsas eram Entre Rios, Porto Itá, Barra do Uvá, Linha Simon, Porto de Goio-en, Chalana, Caxambu, São Carlos, Mondaí e Itapiranga. O percurso entre o local de origem e o destino era de aproximadamente 500 quilômetros e demorava, em média, de três a cinco dias para ser percorrido. As madeiras, na forma de tábuas ou de toras, eram oriundas de pinos ou madeira de lei, como cedro, louro, pinheiro, canela e outros de boa qualidade, abundantes nas matas da região. Cada balsa possuía entre 180 e 200 toras, que podiam ter até 10 metros de comprimento. Cada 10 ou 15 toras 
formava um "Pelotão". As tábuas mediam 5,5 metros. Todas as madeiras eram agrupadas, de acordo com o seu comprimento, e amarradas com cipós ou mesmo com arame galvanizado a travessas de madeira de 20 ou 25 centímetros de diâmetro. Uma balsa de toras podia atingir entre 130 a 150 metros de comprimento. Acima disso, teriam dificuldade de deslocamento em face das muitas curvas do rio Uruguai.

Os balseiros enfrentavam condições de trabalho muito precárias, sem qualquer equipamento de segurança, nem assistência médica e social. Os frequentes acidentes eram um risco que os balseiros tinham que enfrentar por sua própria conta, porque não havia seguro ou qualquer mecanismo de indenização. Tratava-se de uma mão de obra barata e sem garantias de direitos sociais e trabalhistas. Os balseiros levavam uma vida nômade e desprotegida de qualquer assistência e registro na Capitania dos Portos ou no Instituto dos Marítimos. O número de balseiros empregados em cada balsa variava entre dez ou quinze homens, de acordo com o tamanho da balsa, a época da viagem, a capacidade da empresa e a disponibilidade de pessoal. Não há notícias de mulheres que trabalhassem como balseiras. As balsas eram conduzidas por um balseiro prático, que tinha muita experiência no seu ofício. Ele devia conhecer tudo, desde a formação da balsa, o momento certo para o início da viagem, o nível do rio, as corredeiras e os lugares mais perigosos.

As viagens eram feitas em época das cheias, que normalmente aconteciam durante o inverno, mas, eventualmente, podiam ocorrer também durante o verão. Em geral, não costumava haver mais do que quatro enchentes por ano. Nos anos de 1944 e 1945, por exemplo, não ocorreram enchentes, mas em 1946 choveu muito. As enchentes eram ansiosamente aguardadas e tidas como uma "dádiva de Deus", como canta a música de Cenair Maicá "Balseiros do Rio Uruguai": "Oba, viva, veio a enchente, o Uruguai transbordou, vai dar serviço prá gente. Vou soltar minha balsa no rio, vou rever maravilhas, que ninguém descobriu". Mas aquelas expectativas não se realizavam quando não chegava a enchente, provocando grandes frustrações, pelos prejuízos que representavam para a renda dos trabalhadores e para a economia da região. 
Para que uma viagem fosse iniciada, o nível das águas devia estar pelo menos 6 metros acima do normal, no entanto, muitas vezes, as viagens eram feitas com níveis menores. Quanto maior o nível da água, mais rápida era a correnteza e, portanto, menor o tempo da viagem; por outro lado, a velocidade aumentava os riscos e os perigos do percurso. Muitas vezes, as cheias chegavam inesperadamente, fazendo com que se apressasse a montagem das balsas para não se perder a oportunidade, pois a exploração da madeira era a principal atividade econômica da região no período que ia dos anos 1930 a final de 1950. A pressa na montagem das balsas poderia também comprometer a segurança, pois o êxito da viagem dependia muito do estado de amarração das balsas. A viagem podia durar até cinco ou seis dias, navegando-se dia e noite.

Inicialmente as balsas eram manobradas com remos e, mais tarde, também puxadas por barcos a motor. Os balseiros, que conduziam as embarcações, se abrigavam em pequenos ranchos feitos sobre as balsas com madeiras, folhas de árvores ou capim. Havia também um rancho para a cozinha. Quando o rio estava manso e o trajeto ocorria de forma tranquila, muitos patrões acompanhavam as balsas, porém, em geral, seguiam por terra, por considerarem ser mais seguro. A viagem era sempre uma aventura, cheia de perigos. Ao longo do percurso, havia ilhas, remansos, ressorjos e corredeiras, muitos deles bastante perigosos, como o Salto Grande, a Ilha Comprida, as Nove Voltas, as Ilhas Gêmeas. Salto Grande talvez fosse o mais perigoso para as embarcações. Do Porto de Itá até São Borja, contavam-se 49 pontos de referência da viagem, entre portos, saltos, ilhas, enseadas, corredeiras, remansos e os ressorjos ou redemoinhos. Como esses locais exigiam toda a atenção possível, os balseiros passavam dia e noite sem dormir quando atravessavam esses pontos. Muitas toras desprendiam-se das amarrações e se perdiam no rio. Da mesma forma, muitas balsas se desmanchavam e não chegavam ao destino. Eram 16 quilômetros acidentados de muita velocidade das águas. Os acidentes eram frequentes. Como sabiam dos perigos e dos acidentes, os moradores das margens do rio Uruguai estavam sempre preparados para atender possíveis pedidos de socorro de balseiros acidentados. Durante a viagem, havia 
uma divisão do trabalho entre o prático, os remadores e o cozinheiro, mas nas horas mais difíceis todos ajudavam nos remos. Os donos das balsas, em geral pessoas economicamente mais abastadas da região, empresários madeireiros, costumavam fornecer a alimentação para as viagens. A água para beber era levada em garrafões e, quando faltava, reabastecia-se em alguma fonte ou se usavam tubos de bambu para chupar a água do fundo do rio, que era mais limpa.

Quando os balseiros chegavam ao seu destino, em São Borja, encontravam com o patrão, que já estava à espera dos empregados e das madeiras. Algumas vezes eram recepcionados com um churrasco, para comemorar a chegada. Ali mesmo, os trabalhadores recebiam o pagamento. Alguns balseiros gastavam o seu dinheiro em São Borja, em diversões e mercadorias em geral que eram difíceis de obter nos seus locais de residência. Entretanto, a maioria dos trabalhadores do rio trazia o ganho para casa, a fim de investir nos negócios familiares. Em cinco dias, recebiam o valor de dois meses de trabalho normal na região. O retorno acontecia por via terrestre. De São Borja até Santa Maria os balseiros iam de trem. De Santa Maria a Erechim, de ônibus e, depois, andavam a pé até Itá, num percurso de aproximadamente cinquenta quilômetros. A partir dos anos 1950, passou-se a utilizar o caminhão para o transporte dos balseiros, de São Borja até Erechim, e depois os trabalhadores viajavam em ônibus até Itá.

Com a abertura de novas estradas e a implantação de outros meios de transporte, abriram-se perspectivas para o mercado interno da madeira, decaindo a exportação via rio Uruguai.

Essa atividade foi vista como 'Odisseia de balseiros', uma espécie de 'mercantilismo fluvial' que contribuiu para centralizar recursos financeiros nas mãos de madeireiros e comerciantes. O extrativismo foi uma das primeiras atividades capitalistas mais significativas na região, provocando uma renovação na sua vida econômica. O escoamento da madeira, por meio de balsas no rio Uruguai, figurou entre as principais atividades econômicas a partir dos anos 1920, mantendo-se bastante ativa até meados do século. 


\section{REFERÊNCIAS}

BELLANI, Eli Maria. Balsas e balseiros no Rio Uruguai (1930-1950).

CEOM: 20 anos de memórias e histórias no Oeste de Santa Catarina.

Chapecó: Cadernos do CEOM - Ano 19, n. 23, 2006.

. Madeiras, balsas e balseiros no Rio Uruguai. Florianópolis:

EdiUFSC, 1991.

BRUM DE OLIVEIRA, Noeli Woloszyn. Os Trabalhadores do Rio: balsas

e balseiros do Alto Uruguai: 1930-1960. (Dissertação de Mestrado) Passo

Fundo: UPF, 2006.

CORREIO RIOGRANDENSE. Odisseia dos Balseiros. Caxias do Sul, 8/11/1995, ano 87, n. 4.451.

MAICÁ, Cenair. Balseiros do rio Uruguai. (Música). Disponível em:

<https://www.letras.mus.br/cenair-maica/174315/>. Acesso em: 15 mar.

2017. 


\section{Caboclo}

Caboclo é um termo largamente utilizado na sociedade brasileira. Pode ser uma categoria classificatória, de conotação pejorativa, atribuída pelo senso comum para referir-se a pessoas que vivem no campo e que são resultantes da mistura, ora entre o índio e o negro, ora entre o índio e o branco. Pode ser também uma categoria classificatória para pequenos produtores rurais na Amazônia ou no nordeste do Brasil, ou serve para representar o índio em algumas religiões, especialmente naquelas denominações de matriz afro-brasileira. Caboclo também é uma categoria étnica, utilizada por sujeitos em interações com outros distintos sujeitos em situações específicas de reconhecimento de direitos à terra e à prática de certas tradições culturais, podendo ser confundidos com o que se convencionou chamar de índios na sociedade brasileira. A representação do caboclo no folclore nacional e na literatura antropológica têm demonstrado a diversidade de situações nas quais o termo aparece em diferentes regiões do Brasil.

O caboclo do Oeste catarinense apresenta características étnico-raciais, socioeconômicas e culturais particulares. Foi a partir de meados do século XIX que um novo contingente populacional, formado por luso-brasileiros, denominados como caboclos, se tornou predominante na região. O povoamento caboclo se deu inicialmente ao longo do Caminho das Tropas e, depois, avançou para o interior das matas. Via de regra, ele chegava como excedente populacional das fazendas, onde era responsável pelo cultivo de subsistência, e passou a ocupar as zonas de matas e a explorar a erva-mate como atividade de subsistência. Na sua maioria, o caboclo vivia isolado no interior e nas matas da região, numa espécie de solidão natural, longe dos recursos que a modernidade proporcionava às pessoas dos centros maiores. Esse contingente populacional de luso-brasileiros foi um pioneiro desbravador do território Oeste catarinense.

No entanto, apesar da sua relevante contribuição para a formação histórica da região, a história oficial, muitas vezes, silencia ou não confere a devida importância ao caboclo, que em certo momento 
representava a maioria da população do território. De acordo com essa versão, a verdadeira história do Oeste teria começado com a colonização. O caboclo, assim como o índio, não era reconhecido como ente político e social pelas autoridades, que, por isso, não reconheciam seus direitos de posse e sua forma de trabalho.

Como se caracteriza o caboclo do Oeste catarinense? Poli (1995) afirma tratar-se de uma tarefa realmente difícil tentar conceituar o caboclo. Acentua haver autores que procuram defini-lo por suas origens étnicas, buscando as raças básicas que o formaram. Alguns deles contentam-se em definir o caboclo como resultante da miscigenação do branco com o índio. Outros o denominam simplesmente como cafuso, mameluco ou mulato. Na realidade, porém, “o caboclo do Oeste não é simplesmente originário de cruzamento racial puro, mas do cruzamento de indivíduos já miscigenados. O mais importante é saber que a conceituação de caboclo é muito mais social e econômica do que racial." (POLI, 1995, p. 175). O mesmo autor afirma que a sua condição fundamental de reconhecimento é ser pobre e viver toscamente. E conclui que a maior diferença existente entre o caboclo e os "de origem" é a diferença cultural. Era em função disso que muitas famílias de descendentes de italianos ou alemães não admitiam que seus filhos e filhas casassem com caboclos.

O preconceito dos colonos imigrantes contra o caboclo era, realmente, muito acentuado, por considerá-lo um ser inferior, pois não trabalhava da mesma forma que eles e geralmente ser pobre. Embora representassem a maioria da população, os caboclos sempre foram despossuídos e sempre viviam à margem da sociedade, sendo rejeitados pelas novas comunidades de colonos proprietários das terras, migrantes que ocuparam as terras que antes pertenciam aos caboclos. Tanto era assim que, "se melhorasse a sua condição de vida, tornando-se proprietário, comerciante, ou pequeno industrial, deixava de ser chamado de caboclo" (BREVES, 1985). Os caboclos, que conseguiram alguma forma de enriquecimento, bem como seus filhos, que conseguissem algum grau maior de estudos, passaram a denominar-se "portugueses" ou "brasileiros" e não mais admitiam a denominação de caboclos. Poli (2001) acentua, ainda, que o caboclo alimentava uma cultura de respeito entre os membros da família e da comunidade, e destes com os elementos da 
natureza. Para ele, o caboclo era violento apenas quando era atacado, pois os valores humanos que o mesmo possuía se distanciavam dos interesses de poder de apropriação da natureza e das pessoas com as quais convivia. Machado (2012) define caboclo no sentido usado pelos habitantes do Planalto catarinense, com o significado de "pobre do meio rural" e que, mesmo não tendo conotação étnica, era frequentemente apontado como sendo o mestiço ou de origem indígena/africana. A característica principal distingue uma condição social e cultural: "homens e mulheres pobres, pequenos lavradores, peões, devotos de São João Maria”.

Thomé (1992), por sua vez, sintetiza essas características, afirmando que o caboclo era visto como sertanejo, caipira, matuto e acanhado, lento no pensar e no falar, bastante místico, homem desconfiado, face queimada pelo sol, mãos calejadas pelo trabalho, desajeitado no andar, afeiçoado à caça e à pesca, de pele pardacenta, alegre, afeito, trabalhador, bravo, tinha dentro de si o alto sentimento de justiça, do bem, e do coletivismo dos desbravadores e povoadores. Era corajoso, instintivo e violento, ao mesmo tempo em que era franco, leal e honrado.

A identidade cabocla, além desse conteúdo sociológico e cultural, também se define por uma relação especial com a natureza, com o trabalho e com a religião e se afirma a partir de suas lutas políticas em defesa de seus direitos e pela sobrevivência física e cultural. Nesse particular, a identidade cabocla do Oeste catarinense define-se pela oposição sistemática com o ethos do colono, pois a separação social entre caboclo e colono foi sua marca constitutiva. O caboclo, normalmente, via-se rejeitado pelas novas comunidades de colonos que aportavam à região para ocupar suas terras. No conflito que se estabeleceu entre colonos, caboclos e índios, estes dois últimos foram marginalizados e destituídos de suas terras, cultura e métodos de trabalho.

A forma de ocupação das terras pelos caboclos deu-se, em geral, através da posse e não da propriedade legal. A simples posse não legalizada da terra deixava os caboclos em situação de insegurança, pois favorecia a sua desapropriação, como veio a acontecer com a Lei de Terras de 1850. A relação do caboclo com a terra não se resumia a uma questão de posse ou de propriedade, pois ele cultivava uma relação especial com a terra, considerando-a como uma fonte de vida. 
Embora aposse da terra sempre fosse provisória, ela era essencial para a vida do caboclo, pois sem a terra ele não conseguia sobreviver. Ele não possuía a mentalidade da propriedade da terra, como o colonizador, entendia que a terra "era de Deus", ou "do governo", que seria um bem de todos; não compreendia o sentido de sua transformação em mercadoria. A organização do uso da terra e do trabalho era feita em função da subsistência e evoluiu de um sistema nômade, que combinava caça, pesca e extrativismo, para uma combinação do extrativismo, pequena pecuária e agricultura, na forma de roça cabocla. A roça cabocla seguia o sistema de "pousio", ou seja, assentava nas terras mais férteis e produtivas, até se esgotarem, para "pousar", depois, em outro sítio mais propício. Por isso, a residência dos caboclos era semimóvel, acompanhando os seus deslocamentos sempre em busca de melhores condições de sobrevivência.

A história dos caboclos é uma história marcada pela expropriação de suas terras, que foi também uma das principais causas da Guerra do Contestado. A posse da terra era fundamental para o caboclo, que nela cultivava sua pequena roça de subsistência e criava alguns animais soltos. A roça cabocla era dividida em terras de plantar e terras de criar. As terras de plantar localizavam-se distantes da casa e o método adotado no cultivo consistia na derrubada do mato e na queima. Não era necessário capinar a roça, pois a terra fértil favorecia o rápido crescimento de produtos como milho, feijão, mandioca, batata e arroz. Já as terras de criar ficavam mais próximas da casa e abrigavam pequenos animais, como galinhas e porcos. Tudo o que era produzido era para o consumo próprio, pois se tratava de uma economia de subsistência, que não gerava excedente e, portanto, não era comercializada, nem necessitava de moeda de troca.

Nessa economia de subsistência praticamente não circulava a moeda, porque a produção não tinha fins comerciais, o que ressalta o papel das pequenas casas comerciais, mais conhecidas pelo nome de bodegas, como organizações centrais de uma verdadeira economia de escambo, onde se trocava fumo, milho, feijão e erva-mate, por sal, bebidas, querosene, pólvora e instrumentos de trabalho". O nomadismo tornou-se um traço cultural, ou seja, fez parte de habitus do caboclo, 
mas as migrações permanentes eram motivadas pela necessidade de garantir a sobrevivência e a reprodução daquele modo de vida.

Embora representassem a maioria da população, os caboclos sempre viveram à margem da sociedade, servindo de mão de obra barata para fazendeiros, ervateiros e madeireiros. Despossuídos que eram, com o avanço do processo de colonização, raramente conseguiam obter a propriedade de uma pequena área de terra, onde pudessem manter-se com suas pequenas roças caboclas. Por essas razões, a conceituação de caboclo define-se não somente pela miscigenação, mas também por sua contextualização histórica, econômica, social e cultural, por isso caracterizados por uma condição de vida pobre e tosca. Os caboclos sofreram e ainda sofrem uma discriminação étnica e sociocultural, dificultando ainda mais a socialização no Oeste catarinense.

\section{REFERÊNCIAS}

BREVES, W. de Souza. O Chapecó que eu conheci. Revista do Instituto Histórico e Geográfico de Santa Catarina. Florianópolis: 3(6):07-73, 1985.

CEOM - Centro de Memória do Oeste Catarinense (Org). Para uma história do Oeste Catarinense: 10 anos de CEOM. Chapecó: UNOESC, 1995.

MACHADO, Paulo Pinheiro. O movimento do Contestado e a questão de terras. In: Zarth, P. (Org.) História do Campesinato na Fronteira Sul. Porto Alegre: Letra\&Vida, Chapecó: UFFS, 2012.

POLI, Jaci. Caboclo: pioneirismo e marginalização. In: CEOM. Para uma história do Oeste Catarinense: 10 anos de CEOM. Chapecó: UNOESC, 1995.

POLI, Odilon L. Camponeses no Oeste Catarinense. Cadernos do CEOMAno 15 n 14 - Chapecó: Argos, 2001.

RENK, Arlene. A luta da erva: um ofício étnico no oeste catarinense.

Chapecó: Grifos, 1997.

THOMÉ, Nilson. Sangue suor e lágrimas no chão do Contestado.

Caçador: Incon Edições, 1992. 


\section{Caminho das tropas}

O chamado "Caminho das tropas" atravessava o território do Oeste catarinense, tendo seu auge entre meados do século XVIII e meados do século XIX. Ele foi aberto com o objetivo de tropear o gado xucro dos campos gaúchos até as feiras de Sorocaba para alimentar os trabalhadores do café de São Paulo e da mineração em Minas Gerais. Na realidade, houve dois caminhos das tropas: o primeiro deles teria sido aberto por volta de 1728, ligando os campos de Viamão, no Rio Grande do Sul, a Sorocaba, em São Paulo, através dos campos de Lages, território que passou a desempenhar um papel central nesta fase pecuária da economia catarinense. Sorocaba era o maior centro comercializador de animais do país, chegando a reunir, em algumas ocasiões, mais de 200 mil cabeças. Por muitos anos, os animais eram tropeadas do Sul para o Sudeste por este caminho. A ocupação do território em torno desse primeiro caminho durou quase um século, quando, então, se começou a desenhar um segundo caminho das tropas, com as mesmas funções e impactos do primeiro. Por volta de 1810, novas fazendas foram criadas nos campos de Guarapuava, e, em torno de 1838, inúmeras outras se formaram nos campos de Palmas. Foi sobretudo a partir de Palmas e Guarapuava que fazendeiros, vindos do Norte, avançaram mais para o atual Oeste de Santa Catarina, atingindo as terras onde atualmente se situa Campo Erê.

O motivo principal desse deslocamento da ocupação para o Oeste foi que Lages, em 1820, até então ainda fazendo parte da Província de São Paulo, foi incorporada à Província de Santa Catarina e passou a cobrar impostos pela passagem do gado. Em função disso e do avanço das fazendas para o Oeste, foi aberto um novo caminho, entre o Sul e o Sudeste, que estivesse livre da tributação imposta pela comarca de Lages. Esse segundo caminho cortou uma região onde eram mais abundantes os ervais nativos, cuja extração começou a tornar-se atrativa, especialmente para a população sertaneja, que passou a ter nela sua principal forma de interação comercial. O trânsito mais intenso de tropas pelas terras do Oeste, entre as quais estavam as que 
posteriormente foram motivo de disputa pelos estados do Paraná e de Santa Catarina, propiciou a formação de novos pousos, a partir dos quais surgiram novas vilas e a penetração mais intensa de brasileiros em busca da exploração da erva-mate.

Ao longo desses caminhos foi se dando a ocupação do território através da implantação de fazendas para criar gado e do estabelecimento de novos povoados que vieram somar-se aos povoados indígenas já existentes. A ocupação das terras do Oeste com fazendas de criação de gado, além de contribuir para a produção de alimentos, sobretudo para a região dos cafezais paulistas, fazia parte da estratégia de ocupação deste território de fronteira traçada pelos colonizadores portugueses e reforçada por Dom João VI, a partir de 1808. As fazendas eram, de fato, a forma mais rápida, barata e segura de ocupação daquele território. Para fixar esses fazendeiros na região, o governo fazia concessões de terras aos seus ocupantes. Essa fase de formação das fazendas e abertura dos "caminhos das tropas" é considerada como a "fase pecuária" da formação econômica do Oeste de Santa Catarina (BAVARESCO, 2003).

No entanto, além de promover a ocupação dos campos e uma maior e mais profunda penetração populacional no Oeste, a criação de gado teve pouca importância para a formação das bases econômicas da região, pois os fazendeiros não se preocupavam em colonizar as áreas que ocupavam, em função das dificuldades que o cultivo da terra implicava naquela época. Por isso, a agricultura pouco se desenvolveu nesta fase pecuária e as fazendas formavam uma espécie de arquipélagos numa paisagem ainda pouco povoada pelas populações indígenas. Em consequência, o ciclo da pecuária pouco contribuiu para a acumulação original de capital e o posterior desenvolvimento econômico da região. O capital circulante era escasso, em geral associado à comercialização de gado e de alimentos. Diferentemente do que ocorreu no Rio Grande do Sul, no Oeste catarinense não vingou nem a indústria das charqueadas, nem a pequena indústria do couro. A marca desse ciclo da pecuária foi a conquista do território através do latifúndio e da expulsão da população indígena que ali vivia. No entanto, à sua maneira, o ciclo da pecuária teve seu papel para o início 
da formação econômica da região e seu posterior desenvolvimento, pois foi a partir dessa ocupação do território com grandes fazendas que, depois, foram se abrindo meios de transporte e melhorando os meios de comunicação.

Por volta de 1870, com o declínio do ciclo das tropas e das fazendas de criar, processa-se a dispersão da família fazendeira e a fragmentação das grandes áreas de criação de gado. (RENK, 1997). Depois da ocupação dos campos, vinda do Norte, se deu a ocupação das matas, pela população cabocla, e por fim a ocupação pela colonização, a qual inaugura um novo capítulo na história econômica e social desta região.

O declínio do tropeirismo de gado também se explica pelo avanço das ferrovias, que teve grande expansão no final do Império. Mesmo assim, a prática do tropeirismo persistiu até recentemente, quando tropas menores eram deslocadas para frigoríficos. Saliente-se, ainda, que no período da colonização essa prática também foi usada para conduzir suínos, seja para frigoríficos ou para as estações da ferrovia, de onde seguiam para a comercialização.

\section{REFERÊNCIAS}

ALMEIDA, Leo. Tropeiros.(Música).Disponível em: $<$ https://www. youtube.com/watch?v=jHPla4EG3sU>. Acesso em: 20 mar. 2017. BAVARESCO, Paulo Ricardo. Os Ciclos Econômicos do Extremo Oeste Catarinense: modernização, progresso e empobrecimento. (Dissertação de Mestrado). Blumenau: 2003.

PIMENTEL, Airton e FAGUNDES, Antônio Augusto. (música) Tropeiro de Mulas. Interpretação de Daniel Torres. DVD - Tropeiros - Globo Rural. RENK, Arlene. A luta da erva: um ofício étnico no oeste catarinense. Chapecó: Grifos, 1997. 


\section{Colonização}

Colonização implica a relação entre colonizadores e colonizados. No Oeste de Santa Catarina ela foi efetivada principalmente por migrantes descendentes de europeus das antigas colônias gaúchas. O processo ocorreu após o término da Guerra do Contestado (1912-1916) e da definição do acordo de limites interestaduais entre Paraná e Santa Catarina, em 1916, embora muitos colonos do Sul já houvessem migrado para a região, desde o início do século XX. O processo foi conduzido e executado preponderantemente por empresas colonizadoras criadas para tal fim. A colonização estava inserida num espírito capitalista de conquista e apropriação privada da terra, embora, nos primeiros tempos, a economia colonial tivesse pouca relação com o mercado e se assemelhasse mais a uma economia familiar de subsistência, quase autossuficiente e autônoma. Com a expansão da colonização foi se formando um mercado para o comércio dos produtos agrícolas excedentes do consumo das famílias camponesas. Com o desenvolvimento da agricultura e especialmente com a criação de suínos, a produção para o mercado foi se tornando o principal objetivo das atividades econômicas coloniais.

Os colonos sul-rio-grandenses, em geral filhos dos primeiros imigrantes, eram considerados pelas autoridades como mais preparados para a empreitada colonizadora, uma vez que já apresentavam grande experiência com as lides da terra nas antigas colônias do Rio Grande do Sul. Nessa perspectiva se construíram representações que enobreceram o colonizador, adjetivado de progressista, ordeiro, trabalhador, civilizado, etc. Por outro lado, o colonizado (caboclo e populações indígenas) teve sua imagem relacionada à preguiça, à violência e à falta de perspectiva de progresso. Memmi (2007) diz que as representações de "trabalho" e de "preguiça" foram amplamente difundidas para definir a posição de cada grupo, num jogo dialético de exaltação a um e de rebaixamento do outro. Nada melhor para legitimar o privilégio do colonizador do que seu trabalho; nada melhor para justificar a penúria do colonizado do que sua ociosidade. 
Nos anos de 1940, a colonização do Oeste já era bem perceptível e ainda registrava massiva chegada de levas de colonos do Rio Grande do Sul, alemães e italianos e poloneses, em sua maioria com larga experiência no cultivo da terra. A intenção governamental, avalizada por boa parte da intelectualidade e da opinião pública, era colonizar as terras com elementos de origem europeia, por entender que somente com eles seria possível desenvolver a região. Alguns estudos (ROCHE 1969; SUDESUL, 1975) estimam que cerca de 250.000 agricultores gaúchos migraram para as "novas terras" de Santa Catarina, representando cerca de $60 \%$ de todos os que deixavam o Rio Grande do Sul. A maioria deles em idade de 15 a 50 anos, ou seja, em pleno potencial para o trabalho.

O avanço gradativo e implacável da colonização acarretou profundas modificações econômicas, ambientais e sociais para a região, especialmente quando se compara com o período anterior, dos povos indígenas e caboclos. A expansão da propriedade privada da terra e o consequente estabelecimento de divisas (cercamentos) e a produção organizada também com intuito de geração de excedente para o mercado foram gradativamente significando o próprio aniquilamento desses povos da floresta, índios e caboclos, que possuíam a posse coletiva da terra e não os títulos de propriedade. Assim, a colonização ocupou, principalmente, as terras mais montanhosas. Já as áreas de campo haviam se constituído em grandes propriedades dos fazendeiros (de gado) da região, processo que se efetivou em período anterior.

Até o contexto da colonização, as populações indígenas e cabocla do Oeste não possuíam a mentalidade da propriedade privada da terra, guiando-se pela ideia de posse coletiva. Entre os caboclos, o intuito da produção era fundamentalmente o da subsistência, e a produção centrava-se na agricultura de pequena escala, criação de animais e no extrativismo da erva-mate. Com o avanço do processo de colonização essas populações passaram a ser expropriadas do acesso à terra, desestruturando o seu modo de vida e deteriorando a concepção de propriedade que possuíam. Assim, foram introduzidas novas noções de propriedade e de trabalho, diferentes daquela que regulavam a vida até então. 
Muitas diferenças havia entre caboclos/indígenas e colonos, considerando suas diferentes tradições culturais. A forma de como concebiam e organizavam a produção é um exemplo. Enquanto os caboclos produziam fundamentalmente para seu próprio consumo, mantendo pouco contato com o mercado, a produção dos colonos gradativamente "se organizou, em grande medida, em função dele", embora isso não fosse válido para toda a produção colonial, pois a produção para o consumo próprio das famílias continuou a ser feita. Assim, paralelamente ao avanço do processo de colonização, a produção colonial foi progressivamente se integrando ao mercado capitalista, embora ainda mantivesse uma considerável parcela de autonomia em relação a ele. Ao contrário do que se passava com a agricultura itinerante e o seminomadismo dos caboclos, associados ao caráter sazonal de suas atividades, que mantinham a economia cabocla desligada do mercado, parte significativa da economia colonial reforçava cada vez mais seus laços com a economia de mercado.

Embora movido por fins mercantis, o processo de colonização, ao introduzir a pequena propriedade familiar, ajudou a criar um profundo sentimento comunitário e religioso. Numa região em que a presença do Estado pouco ou quase não existia, “o caráter coletivo e comunitário da colonização do Oeste de Santa Catarina foi condição necessária para a reprodução da família camponesa”. Os valores que balizaram a organização da vida comunitária e individual dos colonizadores promoveram uma mudança bastante acelerada na sociedade e, em certa medida, condicionaram a população local a adaptar-se ao novo sistema de propriedade e de trabalho ou a ficar marginalizada. A adaptação significava a desestruturação do modo de vida anterior à colonização. Com a reocupação progressiva das terras, que eram posses dos caboclos/nativos, estas passaram a ser verdadeiros deserdados da terra, além de terem sido destruídas suas tradicionais condições de vida.

O avanço do processo de colonização sobre as novas terras do Oeste catarinense foi formando "ilhas europeias" de colonos italianos, alemães e poloneses, mais voltados para si mesmos e para a natureza, do que para o mundo externo. No período inicial da colonização isso forçou as famílias a produzirem quase tudo o que precisavam e a 
desenvolver relações de ajuda mútua, na forma de mutirões, para dar conta de necessidades individuais ou comunitárias, tendo em vista a ausência do Estado. Assim, as comunidades coloniais formaram "padrões culturais, organização produtiva e modos de vida significativamente diferentes" das populações rurais que ali habitavam. Mesmo que integrados de forma parcial e gradativa ao mercado capitalista, ao mesmo tempo os colonos se integraram e estabeleceram fortes laços de solidariedade e convivência social.

A história da colonização do Oeste catarinense está associada e muito deve à Estrada de Ferro São Paulo-Rio Grande (EFSPRS), que pode ser denominada ferrovia colonizadora, pois o próprio decreto de concessão previa sua utilização em benefício da colonização. Havia, mesmo, um verdadeiro plano de colonização embutido na concessão da EFSPRS, segundo o qual deviam ser assentadas dez mil famílias de agricultores, recebendo cada família um lote de dez hectares, com casas, bem como construção de escolas e igrejas. Durante o processo de assentamento, os colonos receberiam ajuda, em troca de trabalharem 15 dias por mês para a mesma Companhia.

As companhias colonizadoras desempenharam um papel significativo no processo de colonização, principalmente nas áreas não abrangidas pelo projeto da ferrovia. A exemplo do que ocorrera com as terras marginais à ferrovia, concedidas à empresa construtora por força de contrato, o governo catarinense também passou a fazer concessões, a partir de 1917, impulsionando o sistema de colonização por empresas particulares, que deveriam repartir as terras em lotes agrícolas (colônias) e vendê-los aos colonos. Em geral, antes da venda dos lotes aos colonos, as empresas exploravam as madeiras mais nobres existentes nas matas da região. Assim, a colonização não representou um processo espontâneo, mas induzido pelo governo, pois se constituía na forma mais prática de domínio das áreas recém-incorporadas ao estado, tendo em vista que também julgava pouco eficiente a forma de ocupação preexistente, feita por grupos sociais diversos, como os povos indígenas, caboclos e fazendeiros. Tão logo estabelecidos nas novas terras, com seus costumes, crenças, formas de vida, e ancorados 
no suposto "ethos do trabalho", os colonos passaram a constituir-se como grupo social dominante na região.

Embora as terras destinadas aos colonos já estivessem ocupadas pelas populações indígenas e caboclas, criou-se a ideia de que o processo de colonização ocuparia o "sertão" catarinense. A difusão da ideia de "sertão", como espaço vazio, foi um artifício útil para justificar a ocupação de uma terra já habitada. No imaginário social, o "sertão" catarinense ficou associado à ideia de caos, terra de bandido, barbárie, coronelismo e terra de ninguém. Para indígenas e caboclos, a terra tinha fundamentalmente valor de uso e não valor comercial, a posse e não a propriedade (documentada) da terra, fato que favorecia sua expulsão, não raras vezes à revelia da justiça e dos órgãos oficiais do Estado. As disputas de terras eram, geralmente, resolvidas no âmbito privado e à força, o que acabava por favorecer os novos colonizadores.

O Oeste catarinense passou por diversos ciclos de desenvolvimento econômico, como o da pecuária, o da erva-mate e o da madeira. Cada um desses ciclos contribuiu a seu modo para o desenvolvimento regional. Da mesma forma que os ciclos anteriores, a colonização também teve um papel específico neste mesmo desenvolvimento, que foi ter contribuído para o processo de acumulação de capital, com excedentes da agricultura familiar, que se transformou no motor do desenvolvimento do complexo agroindustrial, hoje um dos mais dinâmicos da economia catarinense.

\section{REFERÊNCIAS}

MEMMI, Albert. Retrato do colonizado procedido de retrato do colonizador. São Paulo: Civilização Brasileira, 2007.

RADIN, José Carlos. Representações da colonização. Chapecó: Argos, 2009.

ROCHE, Jean. A colonização alemã e o Rio Grande do Sul. Porto Alegre: Globo, 1969.

RODRIGUES, Márcio Luiz; NEUMANN, Rosane Márcia. Colônias e colonizadoras na região Oeste de Santa Catarina: a atuação da Companhia Territorial Sul Brasil (1925 a 1950). XXVIII Simpósio Nacional de história. Florianópolis: julho de 2015. 
SUDESUL. O Fenômeno Migratório na Região Sul. Porto Alegre:

SUDESUL, 1975.

WERLANG, Alceu Antônio. Disputas e ocupação do espaço no oeste catarinense: a atuação da Companhia Territorial Sul Brasil. Chapecó: Argos, 2006. 


\section{Cooperativismo}

O cooperativismo é um movimento ou uma forma de organização econômica e social orientada por valores e princípios da doutrina cooperativista, tais como a cooperação, a ajuda mútua, a solidariedade, a gestão democrática e a distribuição dos resultados entre os seus associados. O movimento cooperativista se formou como uma reação ao liberalismo econômico da Inglaterra, no final do século XIX, e buscava formas alternativas de organizar as atividades econômicas visando melhorar a vida da classe trabalhadora. As cooperativas podem ser de produção, de consumo, de prestação de serviços ou de financiamento, como são as cooperativas de crédito.

As primeiras cooperativas brasileiras, propriamente ditas, surgem nas grandes cidades, no final do século XIX e início do século XX e são, em geral, cooperativas de consumo, promovidas por sindicatos operários e funcionários públicos. Há informações de que o médico francês Jean Maurice Faivre teria fundado, em 1847, juntamente com um grupo de europeus, a Colônia Tereza Cristina, no Estado do Paraná, que era organizada em bases cooperativistas, apesar de ser difícil justificar a existência de uma cooperativa, antes de 1888, período em que a lei proibia esse tipo de organização, em plena vigência do regime escravista. Há, também, indícios de uma cooperativa de consumo em 1889, em Ouro Preto, e, em 1891, em Limeira, entre funcionários da Companhia Telefônica; em 1894, no Rio de Janeiro, surge a Cooperativa Militar de Consumo; em 1897, em Campinas, forma-se a Cooperativa de Consumo dos Empregados da Companhia Paulista de Estradas de Ferro; em 1913, em Santa Maria, constitui-se a Cooperativa de Consumo dos Empregados da Viação Férrea (COOPFER), que chegou a abranger 18.000 cooperados no auge do desenvolvimento do cooperativismo de consumo no país.

Em Santa Catarina, vale registrar a tentativa de organizar-se uma "associação de famílias" inspirada nos princípios do socialismo utópico do francês Charles Fourier (1772 -1837), que propôs a organização de "falanstérios" ou comunas de produção, uma espécie de sociedade 
baseada na harmonia e na solidariedade, em geral voltada para a agricultura, pela sua profunda relação com a natureza. Trata-se do Falanstério do Saí (SC), onde o médico homeopata Benoit Joseph Mure procurou colocar em prática uma proposta de "socialismo utópico". Para tanto, teve o aval do Imperador D. Pedro II e a concessão de terras e subsídios para sua implantação. A colônia foi iniciada em 1842 e já no ano seguinte encontrava-se em situação animadora, pois ali funcionava, entre outras, uma forja, uma olaria de tijolos e uma serraria mecânica, procuradas por habitantes litorâneos para encomendas. $\mathrm{O}$ grande problema foi o deslocamento de profissionais, pois havia carpinteiros lavrando terras, curtidores plantando, engenheiros fazendo derrubada e fabricantes de máquinas construindo casas. Sendo uma colônia de artesãos e operários especializados, faltou-lhe a necessária base agrícola para a subsistência. Apesar de todos os esforços, não teve um mercado amplo e próximo para consumo dos produtos industrializados, além da dificuldade no desbravamento da densa mata tropical atlântica.

Nos três estados sulinos, o cooperativismo acompanhou o processo de colonização efetuado por imigrantes europeus e seus descendentes. Em Santa Catarina, ao contrário de outros estados, onde se desenvolveram cooperativas de consumo ou de crédito, começaram a desenvolver-se cooperativas agrícolas (ARNS, 2010). A primeira organização cooperativa foi a Societá del Tabaco, criada em 1893 por imigrantes italianos, em Rio do Cedro, na época distrito de Blumenau. Depois, em Urussanga, em 1909, foi fundada a Cooperativa Prima de Rio Maior, a Cooperprima.

As primeiras cooperativas no Oeste catarinense surgiram na década de 1920 e foram inspiradas pelas Caixas Rurais União Popular, criadas no Rio Grande do Sul, em 1902, pelo padre jesuíta Theodor Amstadt. As duas primeiras cooperativas, uma de consumo e crédito e outra uma caixa rural cooperativa, criadas respectivamente em 1925 e 1926, situavam-se em Concórdia. Em 1931, surgiu a Cooperativa de Agricultores de Cunha Porã. Em 1932, foi constituída a Caixa Rural União Popular de Porto Novo, hoje Cooperativa Rural de Itapiranga. A sociedade Cooperativa Palmitos fundada em 1933. Em Canoinhas, 
foi fundada a Cooperativa dos Produtores de Mate de Canoinhas Ltda., em 1934. Outras cooperativas foram criadas em Mafra (1937) e em Campo Alegre (1938).

Nesta região, o cooperativismo começa a se desenvolver a partir da agricultura familiar, no âmbito do processo de colonização, com a chegada de colonos provenientes do Rio Grande do Sul, na década de 1920, os quais trazem consigo o espírito associativo de inspiração missioneira, que esteve na origem do cooperativismo do Noroeste do Rio Grande do Sul. Nesta parte do território gaúcho, as primeiras experiências de cooperativismo tiveram origem e inspiração no modelo de organização social das Missões Jesuíticas, especialmente nos seus princípios de solidariedade, trabalho coletivo, partilha comunitária e da cooperação (ROTTA, BUTTENBENDER e HOFLER, 2016). Além dessa origem missioneira, o cooperativismo do Rio Grande do Sul recebeu inspiração e força do pensamento social-cristão proveniente das igrejas católica e evangélica, que depois também foram fundamentais para o desenvolvimento do cooperativismo na região Oeste catarinense.

A história do cooperativismo nesta região passa por diferentes fases (ARNS, 2010). Uma primeira é caracterizada pelo cooperativismo tradicional ou colonial,o qual, predominantemente associado à "economia colonial", visava, principalmente, organizar a poupança local, a produção e a comercialização do excedente agrícola da agricultura familiar preponderante na região. Essa fase acompanha o processo de colonização por descendentes de imigrantes europeus das colônias velhas do Rio Grande do Sul. Vai de aproximadamente 1920 a meados dos anos 1960, quando surgem as cooperativas de abrangência municipal. A primeira cooperativa da região é constituída em Concórdia, em 1925, e depois em Palmitos e outros municípios. Nas colônias alemãs predominavam as cooperativas de crédito, as "caixas rurais", mas a maioria delas era formada, em todas as colônias, por cooperativas de produção e comercialização, denominadas de cooperativas mistas. Esse movimento inicial de cooperação estava voltado para a solução e a defesa de interesses locais e, num período de pouca presença do Estado, era apoiado pelas igrejas católica e luterana. 
Uma segunda fase pode ser caracterizada por um tipo de cooperativismo empresarial, que vai do período do golpe militar de 1964 até meados dos anos 1980. É nesse período que ocorre a modernização conservadora da agricultura, caracterizada pelo desenvolvimento da grande empresa agrícola, apoiada na estrutura fundiária da grande propriedade. Foi a partir de 1967 que surgiu a maioria das grandes cooperativas existentes atualmente em toda a região Oeste catarinense, tais como: COOPERALFA - Chapecó (1967); COOPÉRDIA - Concórdia (1968); AURIVERDE - Cunha Porã (1968); COOPER Itaipu - Pinhalzinho (1969); COOPERIO - Joaçaba (1969); CASLO - São Lourenço D’Oeste (1975). Ao contrário do caráter municipal das cooperativas da primeira fase, todas as da segunda fase têm um caráter regional. Essas cooperativas empresariais contaram com o apoio e forte investimento do Estado, através do Instituto Nacional de Reforma Agrária (INCRA) e da ACARESC e depois, EPAGRI, no fomento ao cooperativismo, na assistência técnica, no crédito e no apoio tecnológico.

É nessa fase também que o cooperativismo se organiza e se estrutura enquanto movimento efetivamente nacional, com a criação da Organização das Cooperativas Brasileiras (OCB) em dezembro de 1969. Outro passo importante na consolidação do movimento nacional do cooperativismo foi a aprovação da Lei 5.5764/1971, que disciplinou a criação de cooperativas, porém restringiu a autonomia dos associados, interferindo na criação, no funcionamento e na fiscalização, e com isso, conferindo às cooperativas um caráter empresarial. Em Santa Catarina, em 1975, foi fundada a Federação das Cooperativas Agropecuárias do Estado de Santa Catarina (FECOAGRO).

Nesse mesmo movimento, as grandes cooperativas da região procuraram consolidar-se nas duas pontas do processo de comercialização: primeiro, desenvolvendo as condições de infraestrutura de recebimento e beneficiamento da produção de grãos da pequena produção associada e de terceiros e, segundo, a constituição dos departamentos de venda de insumos agropecuários e assistência técnica, com a difusão de uma verdadeira rede de lojas agropecuárias nos municípios e nas comunidades maiores e mais estratégicas, bem como na construção de supermercados. 
Arns (2010) aponta ainda uma terceira fase do cooperativismo, que teria iniciado após Constituição de 1988 e envolve duas direções: de um lado, a consolidação do cooperativismo empresarial, que aprofunda sua lógica capitalista e adquire maior autonomia em relação ao Estado e se consolida em nível nacional e internacional, com a criação da Organização das Cooperativas Brasileiras (OCB), filiada à Organização das Cooperativas da América (OCA), e da Aliança Cooperativista Internacional (ACI). Na outra direção, no período recente, surge um novo movimento associativista na região, vinculado aos movimentos sociais, que se constituíram a partir de meados dos anos 1980, e que vão marcar profundamente a trajetória e o processo de desenvolvimento de toda a região Oeste de Santa Catarina, com reflexos no restante do país.

\section{REFERÊNCIAS}

ARNS, Carlos Eduardo. A Cooperação na Agricultura Familiar no Território Alto Uruguai Catarinense (SC) Brasil. (Dissertação de Mestrado). Santa Cruz do Sul: UNISC, 2010.

ROTTA, Edemar; BUTTENBENDER, P. L.; HOFLER, Cláudio E. A presença dos princípios do cooperativismo no Noroeste do Rio Grande do Sul: revisitando a tradição histórica. In: Corazza e Radin. Fronteira Sul: ensaios socioeconômicos. Florianópolis: Insular, 2016. LINS, Hiyêdo Nunes. Colonização fourierista no sul do Brasil: o Falanstério do Saí (1841-1844). Disponível em: <www.anpec.org.br/ encontro2009/.../000-981bfce87d2adca89d80feb117ff974c.doc $>$. Acesso em: 21 set. 2016. 


\section{Cultura}

A cultura é constituída por um conjunto de símbolos e significados produzidos pelo homem e estabelecidos socialmente, que orientam condutas e comportamentos humanos em sociedade. O ser humano tanto produz cultura como é por ela produzido. Assim, a cultura não deve ser vista como algo já constituído e permanente, mas como algo vivo e dinâmico, que é constantemente reinventado e enriquecido com novos significados (GEERTZ, 1989).

A cultura do Oeste catarinense é resultante da herança cultural indígena e cabocla, superposta pela forte herança cultural colonial e a progressiva imposição de valores culturais associados à modernização capitalista. Esse amálgama de culturas se constitui na base a partir da qual se definirão os traços culturais da região Oeste catarinense. Assim, pode-se dizer que a história cultural do Oeste catarinense está marcada pela sucessão e mistura de diversas culturas típicas dos povos que ali viveram e ainda vivem nos dias atuais, tais como a cultura indígena, a cultura cabocla, a cultura dos colonos e a cultura que resultou deste amálgama cultural e de sua evolução histórica. Assim, a cultura se reelabora nos diferentes processos. Por mais fortes e enraizadas que sejam, as culturas não permanecem sempre iguais e as mudanças mais acentuadas ocorrem quando não há apenas sucessão de culturas, mas uma verdadeira política de destruição de culturas, como ocorreu nesta região com as culturas indígena e cabocla. No entanto, no caso presente, não houve necessariamente uma destruição plena dessas culturas, pois elas ainda persistem nas comunidades originais e foram assimiladas pelos colonos.

As culturas indígenas do Oeste catarinense constituem um diversificado e rico mosaico de tradições, línguas, rituais, mitos, hábitos, visões de mundo e formas de organização social e política que, por trás de sua aparente simplicidade, representam culturas complexas e sofisticadas. Elas se pautam pelo respeito à natureza e por um modo de vida sustentável, na floresta, numa economia de subsistência alimentada pela caça, pesca e coleta de frutos silvestres. Essas culturas 
de tradição indígena estão permeadas pelos valores da religiosidade própria e também por valores herdados de um certo catolicismo popular, das crenças e dos costumes, o culto aos mortos, a culinária típica, o gosto pela música e as variadas formas de expressão artística, suas pinturas, o artesanato, a cestaria e a cerâmica.

A cultura cabocla incorporou muitos dos valores religiosos e culturais dos povos indígenas. Ela também é formada por hábitos, costumes, rituais, crenças, lendas, rezas e benzeduras, saberes e práticas disseminadas no modo de vida caboclo. Também, no processo, ocorreu a reinvenção de muitos desses elementos presentes nas tradicionais festas caboclas, ou em decorrência do contato com outros grupos.

Essa cultura foi atacada, primeiro pela colonização e, depois, pelo avanço das forças da modernização capitalista, que, por sua vez, também afetaram os valores e o modo de vida dos colonos. Mas a cultura cabocla tenta preservar-se, resistindo a esses ataques e mesmo revitalizando-se ao longo do tempo. Não só a manutenção, mas também a transmissão desses elementos culturais é fundamental para a sobrevivência biológica e cultural dos caboclos enquanto grupo étnico-social. Todos esses traços e características específicas estavam muito presentes quando do início do processo de colonização, que provocou um choque entre esses dois grupos étnicos distintos, com culturas bastante diferenciadas, convivendo e disputando o mesmo espaço, em meio a relações marcadas por conflitos e preconceitos mútuos (POLI, 2001). A colonização praticamente destruiu "as condições de sobrevivência e reprodução da cultura e do habitus dos caboclos", da forma como foram construídas na região antes da chegada dos migrantes.

As diferentes características socioculturais de caboclos e colonos têm por base a família, como seu núcleo social central, embora o conceito da família cabocla seja mais amplo que o da colonial. A afirmação da cultura dos colonos se dá através da negação da cultura cabocla, com tudo o que ela significa em termos de valores, hábitos e modo de vida, tanto nos aspectos da produção material, quanto das manifestações culturais. Ao negar os principais elementos da cultura cabocla, a cultura dos colonos foi, aos poucos, incorporando a ideologia e o preconceito das elites dominantes contra a população cabocla. 
Tal perspectiva se construiu no contexto da colonização, especialmente na primeira metade do século XX, quando era corrente entre a intelectualidade a cisão da humanidade em grupos. A eles se relacionava um conjunto de valores positivos ou negativos, principalmente quando se reportava às populações autóctones, caboclas ou mestiças.

A progressiva e cada vez mais intensa integração da agricultura familiar, forma dominante da organização econômica e social dos colonos com o mercado através das relações de troca e do predomínio da forma capitalista de produzir, fez com que o modo de vida e os costumes dos colonos fossem afetados pelos valores de mercado, sem que esse processo implicasse na negação de suas características socioculturais. "Trata-se de um patrimônio cultural original tão enraizado nos valores do trabalho, da parcimônia, da solidariedade e da religiosidade, que consegue se imunizar contra as forças corrosivas do mercado" (POLI, 2001).

A inserção dos colonos no modo de produção capitalista é sempre uma inserção subordinada, mesmo que de um lado signifique a negação da cultura cabocla e de outro a aceitação dos valores econômicos, socioculturais e ideológicos que acompanham o processo de modernização capitalista. Aquela sociedade colonial estava organizada e era regida por um conjunto de valores morais e culturais básicos, que demarcavam os contornos de sua identidade. Entre tais valores, Poli (2001) aponta o "valor do trabalho e do sofrimento, o respeito à propriedade, o caráter sagrado e indissolúvel da família, a regulamentação da sexualidade e da procriação, o princípio hierárquico de autoridade, a importância da vida comunitária, noções de direito e de justiça, retidão e sobriedade na conduta”.

Em síntese, os traços culturais das populações que formam a sociedade do Oeste catarinense, resultam de uma combinação de culturas dos diversos povos que habitaram e dos que ainda habitam a região, como os povos indígenas, a população cabocla, com elementos das culturas africana e portuguesa, e a cultura dos colonos migrantes. Por sua vez, os traços culturais que acompanham o processo de colonização, embora tenham se constituído a base do modo de vida dominante, por um longo período de tempo, não eliminam a permanente 
tensão que enfrentam entre a negação da cultura cabocla e a pressão dos novos valores culturais tipicamente capitalistas, que tendem a afirmar-se com muita força nos tempos atuais.

Por fim, destaca-se a "invenção de tradições" por parte dos diferentes grupos que forjaram a cultura regional. Tornaram-se comuns festas "caboclas", "italianas", "alemãs"..., que, se por um lado inventam elementos de uma suposta tradição étnica, até mesmo para preencher lacunas de perdas sofridas, por outro, revitalizaram o etnicismo em vários sentidos.

\section{REFERÊNCIAS}

GEERTZ, Clifford. A interpretação das culturas. Rio de Janeiro: Guanabara, 1989.

MARQUETTI, Délcio; LOPES DA SILVA, Juraci B. Religiosidade e religião no oeste de Santa Catarina: a crença no monge João Maria e a instituição do Catolicismo. Revista de Humanidades, 11(29), 2011 - jan./jul. Natal: UFRN. Disponível em: <http://www.periodicos.ufrn.br/ojs/index.php/ mneme >. Acesso em: 10 fev. 2017.

POLI, Odilon L. Camponeses no Oeste Catarinense. In: Cadernos do CEOM. Ano 15 no 14 - Chapecó: dezembro/2001.

A luta da erva: um ofício étnico no oeste catarinense. Chapecó: Grifos, 1997.

Identidade Comunitária. III Seminário Temático. Unochapecó, 21/10/ 2004 .

. Sociodiceia às avessas. Chapecó: Grifos, 2006.

SAVOLDI, Adiles. Cultura Kaingang: a educação indígena demarcando as fronteiras da diferença. XI Congresso Luso Afro-Brasileiro de ciências sociais. Salvador: UFBA - 2011. 


\section{Dom José Gomes}

Dom José Gomes foi bispo das Dioceses de Bagé, entre 1961 e 1968, e de Chapecó, entre 1968 e 1998. Ele nasceu em 25 de março de 1921 no atual município de Erechim e morreu, em Chapecó, aos 81 anos, em 19 de setembro de 2002. Seu avô paterno era espanhol e sua avó, italiana, mas seus pais nasceram no Brasil. José era o quinto dos nove filhos de Antônio Gomes e Maria Maggioni. Seu pai era madeireiro, proprietário de uma serraria e morreu de mal súbito, em 1932, aos 45 anos. José fez o curso básico em sua cidade natal e, depois, ingressou no Seminário São José de Santa Maria, onde frequentou o nível científico. Depois seguiu com os cursos de Filosofia e Teologia no Colégio Cristo Rei dos padres jesuítas, em São Leopoldo. Recebeu as ordens menores na cidade de Selbach e foi ordenado padre em 1947, aos 28 anos de idade. Começou suas atividades como vigário cooperador na paróquia de Espumoso, em 1948, onde ficou por dois anos, até 1949. Em 1950, é chamado para trabalhar na Catedral de Santa Maria. Entre 1951 e 1961, desempenhou suas atividades na catedral de Passo Fundo, onde foi membro da Academia de Letras e se envolveu na promoção do ensino superior, ajudando a criar diversas faculdades, dentre as quais a Faculdade de Filosofia, onde também lecionou. Essas faculdades formariam, depois, o embrião da atual Universidade de Passo Fundo.

Em 25 de março de 1961, aos 40 anos, José Gomes é nomeado Bispo da Diocese de Bagé. Como já havia feito em outros lugares onde havia trabalhado, ele costumava envolver-se com as questões sociais, sempre se colocando ao lado dos mais pobres e necessitados. Em Bagé não foi diferente. A questão mais aguda daquele momento era a da reforma agrária. Os trabalhadores tentavam organizar-se através da criação do Sindicado dos Trabalhadores Rurais, organização não aceita pelos proprietários de terras. A tensão e o conflito entre os sem-terra e os fazendeiros intensificaram-se. Dom José, desde o início, tomou posição firme em defesa do direito dos trabalhadores em formar seu sindicato. Mas sua luta foi bruscamente interrompida. Inexplicavelmente, de uma hora para a outra, em 1968, Dom José foi 
transferido para a Diocese de Chapecó. Foi uma transferência difícil de explicar. Causou estranheza e consternação. Houve muitas manifestações e protestos.

Em Chapecó, desenvolveu ampla atuação por meio das Pastorais Sociais, como a Pastoral da Saúde, a Operária, a da Juventude e principalmente a da Comissão Pastoral da Terra (CPT), da qual também foi presidente nacional. Desde o início, Dom José deu continuidade a suas atividades de defesa e apoio aos movimentos sociais. As frentes eram muitas. Movimento dos Trabalhadores Rurais Sem-Terra (MST), Movimento de Mulheres Agricultoras (MMA), hoje denominado Movimento de Mulheres Camponesas (MMC) e o Movimento dos Atingidos por Barragens (MAB). Assumiu, também, a defesa dos interesses indígenas, atuando através do Conselho Indigenista Missionário (CIMI), que ajudou a criar e do qual foi seu primeiro presidente.

No seu intenso trabalho social, mostrava-se sempre preocupado com a violência que os trabalhadores sem-terra pudessem sofrer e recomendava muita cautela nas ocupações de terra, temendo a reação dos proprietários e seus métodos violentos. Em nenhum momento, porém, deixou de reconhecer e de apoiar o direito dos trabalhadores de lutar pelos seus interesses. "Defendemos o direito que o povo tem de lutar pela terra". "Eu era contra a invasão, mas os trabalhadores são autônomos", não me cabe dar ordens, "eles não pediram nem a minha bênção", afirmou ele, brincando, antes de uma ocupação. "O método da invasão é novo, mas é deles”. Julgava ser uma forma legítima de pressão para que as autoridades reconhecessem o direito dos trabalhadores a possuírem sua terra para trabalhar.

Lutou sempre por uma igreja menos hierarquizada, menos apegada às tradições seculares e mais aberta para as causas populares. Nas décadas de 1970 e 80, os conflitos foram mais intensos, mas Dom José nunca esmoreceu, apesar das perseguições e ameaças que sofreu. Ele se manteve sempre firme na defesa dos direitos dos pequenos e excluídos, quer fossem índios, trabalhadores sem-terra e pequenos agricultores. Dom José sempre defendeu a todos e, por isso, o povo o referenciava como o "porta-voz da justiça". Ele sofria muitas pressões das elites locais. Em 1968, em meio a grandes conflitos, o Governo do Estado 
solicitou sua intermediação. Dom José nunca se negou a colaborar, mas deixou claro para as autoridades que "é com o MST que vocês têm que negociar" e não comigo. Ele tinha uma aguda lucidez política e habilidade para incentivar as pessoas a lutarem por seus direitos.

Sua ação e suas lutas devem ser entendidas no contexto das grandes transformações pelas quais passou o Oeste catarinense, como foi o avanço agressivo do capitalismo no campo, o novo modelo de produção voltado para a exportação, o surgimento das grandes agroindústrias, a concentração da terra, o êxodo rural, os problemas decorrentes da urbanização e o processo de marginalização dos pequenos agricultores. Sem Dom José, a história do Oeste catarinense seria outra. Ele foi um "arquiteto de consciências". As elites locais se opunham à atuação social de Dom José e promoviam campanhas difamatórias e ataques violentos; a opinião pública oficial, a prefeitura municipal e as forças econômicas e políticas, através dos meios de comunicação, rádios, jornais e televisão, responsabilizavam o bispo pelos conflitos.

Dom José Gomes trabalhou durante mais de trinta anos na Diocese de Chapecó. Entretanto, sua liderança e suas ações em defesa dos direitos dos sem direitos fizeram-se sentir em todo o Brasil. Em 1998, aposentou-se de suas funções oficiais, permanecendo como bispo emérito, até sua morte, em 2002. Seu corpo está enterrado na própria catedral de Chapecó.

\section{REFERÊNCIAS}

CEOM. Sermões do Bispo Dom José Gomes. Chapecó: Argos, 2012. GOBBO, André. Dom José Gomes Escudo dos Oprimidos. São Paulo: Paulinas, 2002.

UCZAI, Pedro. Dom José Gomes: mestre e aprendiz do povo. Chapecó: Argos, 2002. 


\section{Erva-mate}

A erva-mate era uma planta nativa de várias regiões do Paraná, de Santa Catarina e do Rio Grande do Sul, ao longo da Fronteira Sul. Estava disseminada nas matas do Oeste, mas seu maior produtor era o Planalto catarinense. Sua coleta era uma atividade nômade e sazonal, pois o intervalo entre uma poda e outra demorava em torno de três anos, exigindo o deslocamento daqueles que a extraíam. Por isso, não havia necessidade de as pessoas se fixarem em locais próximos aos ervais. A extração da erva-mate foi uma importante atividade econômica da região, fornecedora do produto para outros mercados consumidores, pois o mercado local era pequeno e incapaz de absorver toda produção, dado que os moradores locais, em geral, produziam a erva para seu próprio consumo. Sua importância econômica era tão grande que sua atividade foi denominada de ciclo da erva-mate, um ciclo bastante longo na história da região (RENK, 1997), estendendo-se da segunda metade do século XIX até o final das primeiras décadas do século XX.

O ciclo da erva-mate representou, antes de tudo, a ocupação das matas. De modo geral sua exploração era feita no interior das matas pelos caboclos, que viviam na região e, de modo geral, trabalhavam como peões a serviço de outros exploradores. A extração da erva-mate só se tornou atrativa e rentável a partir de 1850, com a chegada de exploradores argentinos e paranaenses, que se dedicaram mais fortemente ao seu beneficiamento e industrialização. Seu maior desenvolvimento, porém, só veio a ocorrer mesmo no final de século XIX, quando sua produção começou a ser exportada para os mercados externos da região, tendo em vista que o consumo local era pequeno.

O trabalho de poda e coleta da erva-mate era feito principalmente pelos caboclos que habitavam a região. Eles levavam vida simples e rudimentar, habitavam pequenos ranchos, agrupados em pequenas comunidades isoladas no interior das matas, distante de tudo, viam seus familiares nascer, crescer e morrer, abandonados à própria sorte. Produziam alimentos, criavam pequenos animais, como o porco, a galinha e o gado e mudavam constantemente de residência. Eles se 
deslocavam, com seus poucos haveres, instalando-se ora aqui, ora acolá, vivendo da caça, das pequenas "roças caboclas" de subsistência, em clareiras no interior das matas, geralmente cuidadas pelas mulheres, e da extração da erva, que era vendida aos ervateiros ou aos intermediários. Enquanto o preço da erva era rentável, essa população manteve condições de vida regular. Porém, com a decadência do ciclo da erva-mate, habitar aquelas áreas ficou insuportável. Não existia mais comércio e faltava dinheiro para comprar até mesmo os produtos básicos (POLI, 1989; RENK, 1997).

A economia ervateira, explorada por paranaenses, argentinos e catarinenses, apesar de não oferecer um produto de boa qualidade e, por isso mesmo, pouco competitivo, sempre esteve atrelada ao mercado externo, o principal consumidor de erva-mate para o chimarrão. Os principais mercados consumidores estavam no Paraná e no Rio Grande do Sul, mas principalmente na Argentina. A comercialização para esses mercados era feita quase livremente, sem cobrança de impostos, pois havia pouca presença e controle do governo nessa região, no final do século XIX e início do século XX. O transporte da erva para o mercado argentino, de modo geral, era feito em lombo de mulas, em bruacas, tornando o produto vulnerável à chuva e ocasionando perda de qualidade, até Baracón, cidade argentina fronteiriça, onde a população do Extremo Oeste catarinense se abastecia de produtos, como sal, banha e munição, indispensável para a vida nos campos, bem como para aqueles que se embrenhavam nas matas à procura de plantas nativas da erva. A abertura de estradas, o beneficiamento em monjolos e pilões mecânicos dinamizou ainda mais a produção ervateira no Oeste catarinense, antes de ser exportada para outras regiões do Brasil e do exterior. Em Chapecó, Palma Sola e Campo Erê chegaram a desenvolver-se alguns sistemas de beneficiamento, mas essas pequenas indústrias pouco prosperaram dadas as condições adversas da época na região, entre outras causas, também devido à distância entre a produção local e os mercados consumidores. Porém, a industrialização incipiente da erva-mate não resistiu à crise que atingiu sua produção na região, nas primeiras décadas do século XX. 
$\mathrm{O}$ auge do ciclo da erva-mate na região Oeste catarinense foi em 1930, quando sua produção chegou a 280 mil toneladas. A crise da economia ervateira, contudo, já começa a manifestar-se por volta de 1910, quando a Argentina iniciou o plantio de ervais na Província de Misiones, diminuindo, então, a demanda do produto brasileiro, que começa a entrar em declínio. A partir de meados da década de 1930, com o desenvolvimento da agricultura colonial, a exploração da erva- mate deixou de ser a principal atividade econômica da região, mas não desapareceu. Ela continuou a ser cultivada e beneficiada para atender à demanda de consumo da própria região e não mais como relevante produto de exportação, como acontecia em décadas anteriores, no auge do seu ciclo de produção.

\section{REFERÊNCIAS}

BAVARESCO, Paulo Ricardo. Os Ciclos Econômicos do Extremo Oeste

Catarinense: modernização, progresso e empobrecimento. (Dissertação de Mestrado). Blumenau: 2003.

LINHARES, Temístocles. História econômica do mate. Rio de Janeiro: José Olímpio. 1969.

POLI, Jaci. Caboclo: pioneirismo e marginalização. Cadernos do CEOM. Chapecó: v. 4, n. 7, 1989.

RENK, Arlene. A luta da erva: um ofício étnico no oeste catarinense. Chapecó: Grifos. 1997. 


\section{Estrada de Ferro SP-RS}

A Estrada de Ferro São Paulo-Rio Grande do Sul (EFSPRS) interligou a região Sul com a região Sudeste do Brasil. Foi projetada pelo engenheiro João Teixeira Soares, ainda em 1887, com um percurso de 1.403 $\mathrm{km}$, entre a cidade de Itararé, em SP, e a cidade de Santa Maria, no Rio Grande do Sul, permitindo uma conexão das malhas ferroviárias do Brasil, Uruguai e Argentina. Ela foi construída por etapas, em diferentes períodos. O trecho desta ferrovia, entre os rios Iguaçu e Uruguai, na cidade gaúcha de Marcelino Ramos, numa extensão de 347 $\mathrm{km}$, passando pelo Meio-Oeste catarinense, foi inaugurado em 1910. De alguma forma a ferrovia representou o novo "caminho das tropas", através do qual os campos gaúchos abasteciam os mercados paulistas e mineiros com gado e mulas, mas seus objetivos eram muito mais amplos do que o transporte de animais. Com a construção da EFSPRS, o Oeste catarinense inaugurava uma nova fase de sua história, inserindo-se na economia nacional e nos circuitos econômicos internacionais.

A EFSPRS resultou de um conjunto de fatores internos e externos, como o interesse do capital internacional, as necessidades regionais e a vontade política do Governo Federal. Do ponto de vista externo, o final do século XIX era um período de expansão do capitalismo mundial, com exportações de capital e tecnologia e conquista de novos mercados, processo associado à Segunda Revolução Industrial e à formação das grandes corporações multinacionais. Do ponto de vista interno, além do motivo estratégico de ocupação de um território de fronteira, a ferrovia servia ao propósito de fortalecer integração de toda a região sul à economia nacional, pois na passagem do Império à República o Brasil ainda era um país fragmentado, com muitos conflitos regionais, carente de investimentos externos, especialmente para desenvolver sua infraestrutura e fortalecer o mercado interno. Assim, pode-se dizer que no Oeste catarinense o capitalismo chegou de trem, no início do século XX, com todas as suas consequências, em termos de desenvolvimento capitalista, cortando distâncias, aproximando cidades, unindo mercados, despertando sonhos e ilusões, mas também 
com todas suas contradições e conflitos, esmagando vidas humanas sob seus dormentes, bem como destruindo valores e identidades das populações nativas. Foi assim, na Europa e nos Estados Unidos. Foi assim, também, no Oeste catarinense.

Embora as negociações efetivas para a construção desta ferrovia só tenham acontecido após a incorporação do território do Oeste catarinense ao território brasileiro, em 1895, sua história começa um pouco antes, em novembro de 1889 , às vésperas da proclamação da República, quando Dom Pedro II outorgou a concessão da ferrovia a João Teixeira Soares, possuidor de extraordinária visão estratégica e experiência nesse ramo. Credenciais não faltavam a este engenheiro, empresário, financista e proprietário de terras, pois antes já havia construído o difícil trecho que vai de Curitiba a Paranaguá. Logo após receber a concessão, ainda em 1890, Teixeira Soares criou a Compagnie Chemins de Fer Sud Ouest Brésilien, com capitais belgas e franceses, visando captar recursos para a construção da ferrovia que integraria essa parte do território catarinense à economia nacional e internacional.

Os trabalhos de construção da EFSPRS iniciaram em 15 de novembro de 1895 e o primeiro trecho, de $228 \mathrm{~km}$, foi inaugurado em 16 de dezembro de 1899. Em abril de 1904, a ferrovia chegou às margens do Rio Iguaçu, na divisa com Santa Catarina. Nesse momento, estava em operação todo o trecho paranaense, além do gaúcho, entre o Rio Uruguai e Santa Maria, faltando concluir apenas o trecho catarinense, entre os rios Iguaçu e Uruguai, para o qual foram recrutados muitos operários na própria região e em algumas cidades brasileiras. Muitos outros operários especializados também vieram do exterior. Estima-se que no auge da construção o contingente de mão de obra possa ter atingido o montante de 8.000 trabalhadores. A estrada foi construída na base da picareta, a um ritmo alucinante de 516 metros por dia. A inauguração final da obra só veio a ocorrer em 17 de dezembro de 1910.

Em 1908, a EFSPRS, que passava por dificuldades financeiras, foi vendida para o poderoso grupo norte-americano de Percival Farquhar, dono da Brazil Railway Company. Farquhar já havia construído a estrada de ferro Madeira-Mamoré e chegou a controlar quase metade da malha ferroviária nacional. O Grupo Farquhar era um 
conglomerado de empresas de diversos ramos espalhados por vários países. Percival Farquhar era engenheiro, financista e deputado nos Estados Unidos. Foi quando vendia máquinas agrícolas com seu pai para países da América do Sul que percebeu as grandes oportunidades de investimentos lucrativos, expandindo seus negócios para os países da América Central e do Sul, em Cuba, na Argentina, no Uruguai e na Bolívia. Seus negócios se estendiam a vários outros ramos, como eletricidade, gás, portos e companhias de navegação. Com suas empresas de navegação controlava os portos de Belém, Rio de Janeiro, Rio Grande e Paranaguá. Percival Farquhar sonhava com a construção de um império, que envolvia o controle dos transportes na América Meridional, abrangendo Argentina, Uruguai, Paraguai e Brasil.

No Oeste catarinense, além da ferrovia, o Grupo Farquhar operava também com a Southern Brazil Lumber \& Colonization Company, com a finalidade de explorar a madeira e colonizar a faixa de terras e matas de 15 quilômetros de cada lado dos trilhos, que recebeu como parte do pagamento pela construção da ferrovia.

A EFSPRS contribuiu enormemente para as atividades madeireiras e, além disso, foi considerada ferrovia colonizadora. A própria colonização do Oeste catarinense confunde-se em grande parte com o avanço da história da ferrovia. Além disso, a construção da ferrovia São Paulo-Rio Grande tem relação direta com a Guerra do Contestado, pois a nova realidade criada pela operação da ferrovia afetou fortemente o modo de vida das pessoas que residiam em sua área de abrangência, gerando descontentamento entre os sertanejos.

A EFSPRS foi, sem dúvida, a maior obra do início do século XX no Oeste catarinense, pois além de seu papel estratégico-militar de defesa territorial, ela desempenhou um papel econômico fundamental, contribuindo para o avanço da colonização e o desenvolvimento da indústria ervateira e madeireira, facilitou o transporte de mercadorias, as ligações entre cidades e a integração da região ao território brasileiro e à economia nacional. Em torno das estações do trem formaram-se núcleos urbanos e atividades econômicas variadas, irradiando o processo de mudança e desenvolvimento da região. 
O Império Farquhar desmoronou com a Primeira Guerra Mundial. Afetada por dificuldades financeiras, a EFSPRS foi encampada pelo Governo Federal, na década de 1940 e, depois, em 1996, foi novamente devolvida à iniciativa privada, no contexto das privatizações do governo Fernando Henrique Cardoso.

\section{REFERÊNCIAS}

ESPIG, Márcia J. Personagens do Contestado: os turmeiros da Estrada de Ferro São Paulo-Rio Grande do Sul (1908-1915). Pelotas: UFPEL, 2011.

GOULARTI FILHO, Alcides. A Estrada de Ferro São Paulo-Rio Grande na formação econômica regional em Santa Catarina. Florianópolis, Geosul, V. 24, N. 48, 2009. NODARI, Renato. Estrada de ferro São Paulo-Rio Grande: causas e consequências de sua construção em território catarinense (1900-1940). (Dissertação). Porto Alegre: UFRGS, 1999. 


\section{Formação econômica}

O processo da formação econômica da região Oeste catarinense deu-se através de uma série de fases ou ciclos, que se estendem de meados do Século XIX, com as atividades de pecuária e a ocupação dos campos, através das grandes fazendas de criar, e começam a declinar depois da metade do século XX, quando se consolida a indústria frigorífica, especialmente a de carne suína, pois a industrialização avícola só vem a acontecer duas décadas depois, por volta de 1970.

A conquista do território, em suas diferentes fases, acompanha sempre a evolução das atividades produtivas, desde a pecuária extensiva até a indústria frigorífica, permeadas pela conquista das matas com a extração da erva-mate, a atividade madeireira, o processo de colonização e o desenvolvimento peculiar da agricultura familiar, base da formação do moderno complexo agroindustrial. A formação econômica do Oeste catarinense resulta, assim, de um longo e peculiar processo histórico, cujo traço principal talvez tenha sido seu alongado isolamento e sua tardia incorporação à economia nacional.

No início de sua formação econômica, o Oeste catarinense era um corredor de passagem entre São Paulo e Rio Grande do Sul. Por ali havia sido aberto pelos tropeiros o chamado "Caminho das tropas", que conduzia o gado xucro dos campos gaúchos, para alimentar os trabalhadores do café de São Paulo e da mineração de Minas Gerais. Ao longo desses caminhos foi se dando a conquista do território pelo homem branco, através da implantação de fazendas para criar gado e do estabelecimento de novos povoados, ao lado dos que já havia na região. Nessa fase pecuária da formação econômica, além de promover a ocupação dos campos e uma maior e mais profunda penetração populacional no Oeste, a criação de gado teve pouca importância para a formação da base econômica da região. Os fazendeiros não se preocupavam em adensar a população das áreas que ocupavam, em função das dificuldades que isso implicava, deixando de povoar grande parte daquela imensa área, especialmente as matas nativas. Por isso, a agricultura pouco se desenvolveu na região nesse período. As atividades 
da pecuária tiveram mais um papel de conquista do território, uma vez que foi muito reduzida sua contribuição para a acumulação original de capital e o posterior desenvolvimento econômico regional (BAVARESCO, 2003). O capital circulante era escasso, em geral associado à comercialização de gado e de alimentos. Por volta de 1870, o ciclo da pecuária entra em declínio (RENK, 2006), juntamente com as fazendas de criar. Como consequência, as grandes fazendas se fragmentam, quer pelas heranças, quer pelas partilhas, e as populações que nelas viviam se dispersam.

Ao mesmo tempo em que se dá a conquista dos campos, vinda do Norte, processa-se a conquista das matas, pela população cabocla. O aprofundamento da conquista e ocupação do território em direção ao Oeste, saindo dos campos em direção às matas, propiciou também o descobrimento de uma nova riqueza nativa, a erva-mate, e uma nova atividade econômica, que se mostrou de fundamental importância para o desenvolvimento da região (BAVARESCO, 2003). Nos seus primórdios, a economia da erva-mate era uma atividade de coleta, nômade e extensiva, feita pela população cabocla, no interior das matas. Os caboclos, que levavam vida rudimentar, viviam em pequenos ranchos, produziam alimentos, criavam animais, porco, galinha, gado e mudavam constantemente de residência. Por isso, a extração de erva-mate nativa pode ser considerada uma atividade nômade e sazonal, entre uma poda e outra, que levava cerca de três anos. Os principais mercados consumidores da erva-mate, neste período, eram o Paraná, o Rio Grade do Sul e principalmente a Argentina. Em geral, tratava-se de um comércio quase livre, sem cobrança de impostos, devido à pouca presença e controle do governo na região. O ciclo da erva-mate, como atividade econômica relevante, foi relativamente longo (RENK, 1997), estendendo-se das últimas décadas do século XIX até o final das primeiras décadas do século XX.

Além da extração da erva-mate, a população cabocla se dedicava ao plantio de pequenas roças para a produção de alimentos necessários à sua subsistência. Esta atividade agrícola ficou conhecida como roça cabocla, que era feita em clareiras abertas na mata, através de queimadas. 
A construção da Estrada de Ferro SP-RS (EFSPRS), no início do Século XX, desempenhou um papel muito relevante para a formação econômica do Oeste catarinense. Por sua importância estratégica e pelas atividades econômicas que impulsionou, pode-se dizer que foi através dos trilhos do trem de ferro que o capitalismo chegou ao Oeste catarinense (GOULARTI FILHO, 2009).

Depois do ciclo da erva-mate veio o ciclo da madeira (BAVARESCO, 2003), que alcança seu auge entre 1930 e 1950 e termina uma década mais tarde, com o esgotamento dos pinhais de corte e de outras madeiras nobres. As atividades madeireiras, embora tenham contribuído para o povoamento e urbanização da região, através criação de vilas rurais, onde residiam os trabalhadores, não foram muito importantes para a formação inicial do capital e o desenvolvimento da região, pois os recursos por elas produzidos, eram enviados para fora, deixando de ser investidos na região. A herança que deixaram foi a devastação quase completa das matas, que antes cobriam esse imenso território.

Além de contribuir enormemente para as atividades madeireiras, a ferrovia foi uma ferrovia colonizadora, pois a história da colonização do Oeste catarinense confunde-se com a história da ferrovia (ESPIG, 2011). Assim, foi sem dúvida a partir da construção da estrada de ferro que se deu a inserção de parte da economia de Santa Catarina no mercado nacional e internacional, pois ela influenciou de maneira profunda e permanente o desenvolvimento econômico do Oeste catarinense, alterando a estrutura de propriedade das terras e a forma de exploração dos recursos naturais da região.

O ciclo da colonização e da agricultura familiar mudou os rumos da economia regional. O processo de colonização trouxe grandes transformações para o Oeste catarinense, não apenas em relação à ocupação do território, mas também no tocante às relações sociais que se desenvolveram nas novas colônias, alterando modo de vida, lazer, trabalho, uso da terra e o cotidiano cultural dos colonos. A agricultura familiar desenvolveu-se a partir da colonização, que inicia principalmente após a definição interestadual de limites e do fim da Guerra do Contestado, e se intensifica a partir de 1940, com a chegada de novas 
levas de colonos do Rio Grande do Sul, sobretudo alemães e italianos, mas também poloneses, que traziam consigo uma larga experiência no cultivo da terra. Assim, ao contrário do que havia acontecido com os ciclos anteriores da pecuária, da erva-mate e da madeira, que se mostraram incapazes de iniciar um processo de acumulação de capital na Região (BAVARESCO, 2003), a agricultura familiar contribuiu decisivamente para a formação do capital comercial e sua posterior transformação em capital industrial, base do complexo agroindustrial que se desenvolveu na região, hoje um dos polos mais dinâmicos da economia catarinense.

A formação econômica do Oeste consolida-se e se completa com a formação e o desenvolvimento do complexo frigorífico e agroindustrial. Iniciado no decorrer da década de 1940, o sistema agroindustrial ganhou impulso a partir do final da década de 1960, mas foi nos anos 1980 que esse movimento se intensificou. Esse moderno complexo agroindustrial resultou da bem-sucedida integração da agricultura familiar com a indústria frigorífica, que, por sua vez, constitui a base do atual modelo de desenvolvimento do Oeste catarinense. Nos anos 1990, houve uma profunda reestruturação na agroindústria na região, afetando as relações entre agroindústria e agricultura familiar em torno da suinocultura, provocando o abandono dessa atividade por milhares de agricultores, muitos dos quais engrossaram o fluxo migratório em direção a outras regiões. As empresas líderes, Sadia e Perdigão, efetuaram reorganizações societárias e procuraram instalar-se junto aos grandes mercados consumidores do País, assim como fortaleceram sua inserção internacional. Efetivamente, a agroindústria regional trilhou o caminho da concentração, com fusão entre Sadia e Perdigão, da qual resultou a Brasil Foods (BRF). Mais recentemente, o grupo JBS adquiriu o Seara, o Marfrig e outros frigoríficos de porte médio. Atualmente, apenas algumas poucas e grandes empresas dominam o setor, destacando-se BRF, Aurora e JBS. Todo esse processo de concentração empresarial tornou muito mais complexa a estrutura econômica e social da região. 


\section{REFERÊNCIAS}

BAVARESCO, Paulo Ricardo. Os Ciclos Econômicos do Extremo Oeste

Catarinense: modernização, progresso e empobrecimento. (Dissertação de Mestrado). Blumenau, 2003.

ESPIG, Márcia J. Personagens do Contestado: os turmeiros da Estrada de Ferro São Paulo - Rio Grande do Sul (1908-1915). Pelotas: UFPEL, 2011. GOULARTI FILHO, Alcides. Formação Econômica de Santa Catarina. Florianópolis: UFSC, 2007.

RADIN, José Carlos. Representações da Colonização. Chapecó: Argos, 2009.

RENK, Arlene. A Colonização do oeste catarinense: as representações dos brasileiros. In: CEOM: Para uma história do Oeste Catarinense: 10 anos de CEOM. Chapecó: UNOESC, 1995.

. A luta da erva: um ofício étnico no oeste catarinense. Chapecó: Grifos, 1997.

. Sociodiceia às avessas. Chapecó: Grifos, 2006. 


\section{Formação política}

A formação política da região Oeste catarinense teve uma forte conotação coronelista e oligárquica. Desde os primeiros tempos da conquista do território, a política local esteve nas mãos dos coronéis, que exerciam sua dominação política através de um acentuado mandonismo, uma expressão local do tradicional coronelismo brasileiro.

No Brasil o coronelismo enraizou-se na estrutura social e política e, desde os tempos coloniais, atravessou o Império e se consolidou durante a República Velha. Espalhou-se e reconstituiu-se em novos contextos econômicos, sociais, políticos e culturais, como foi o caso do Oeste catarinense. Esse sistema de dominação política, que faz parte da formação política e social brasileira, teve duas fases, que podem ser denominadas "velho coronelismo rural" e "novo coronelismo urbano". De forma geral, o coronel, além de posto na estrutura militar, ficou conhecido como aquele personagem que tem grande poder econômico e político, cujas patentes podiam ser compradas com somas de dinheiro que o poder público exigia. Embora a Revolução de 1930 tenha pretendido romper com o velho coronelismo, com a "política dos governadores" e suas farsas eleitorais, não chegou a efetivar essa ruptura com as velhas estruturas de poder. O que ela fez, de fato, foi aliar-se aos novos coronéis.

O velho coronelismo rural, que também dominou a política no Oeste catarinense durante o Império e a República Velha até meados do Século XX, tem suas origens no Século XIX, com a criação da Guarda Nacional, quando a região ainda era vista como um "grande sertão", pertencente à província de São Paulo, cujos postos de "coronéis" eram distribuídos a pessoas civis, os grandes senhores de engenho no Leste e Nordeste, e os caudilhos e os fazendeiros no Sul. Nesse sistema coronelista de poder, o posto de oficial era entregue a capatazes das fazendas e a importantes aliados políticos. Os postos de soldados eram entregues a agregados, peões e capangas dos fazendeiros. Assim, o coronelismo reforçava politicamente o poder econômico de grandes fazendeiros que exerciam o poder político pelos diferentes "sertões" 
do Brasil. No Oeste catarinense não foi diferente. Esses fazendeiros, na sua maioria, eram remanescentes dos antigos tropeiros, que, munidos de "patentes de coronel", juntamente com seus peões, constituíam os batalhões da Guarda Nacional e concentravam toda a estrutura de poder durante o Império. Dessa forma, na segunda metade do Século XIX, todo o poder estava concentrado nos fazendeiros coronéis, que administravam suas terras, ditavam ordens, influenciavam a política nas vilas próximas e decidiam as eleições regionais. Nesse sistema coronelista, o fazendeiro detinha um poder quase ditatorial, pois era, simultaneamente, governante, juiz, delegado e legislador.

O mandonismo e o coronelismo, típicos da formação política brasileira, assumem características específicas na formação política do Oeste catarinense (HASS, 1999; 2002). Inicialmente, foi o velho coronelismo rural que dominou a política desta região até, pelo menos, o fim da Guerra do Contestado, em 1916, e o início da colonização, quando um novo coronelismo, de caráter urbano, começou a gestar-se e passou a exercer o poder e a dominar a política regional. No tempo do velho coronelismo rural, os fazendeiros da região alinhavam-se ao Partido Conservador, ao Partido Liberal e ao Partido Republicano, mas a representação política era mais familiar do que partidária, dominada que foi, até 1917, pelo grupo de Lauro Müller e Vidal Ramos. Depois, foi o grupo ligado a Hercílio Luz, que passou a dar as cartas na política regional.

A partir da colonização, com a gradativa chegada de migrantes e o surgimento de novas vilas e cidades e, especialmente com o início da agroindustrialização na região, o velho coronelismo rural foi cedendo lugar ao novo coronelismo urbano, que já predominava na região do litoral catarinense. $\mathrm{O}$ novo coronelismo no Oeste afirmou-se, a partir da nova realidade regional, marcada pelo término da Guerra do Contestado, a solução do conflito sobre os limites entre os estados do Paraná e Santa Catarina e a criação dos municípios Cruzeiro e Chapecó, em 1917. Embora o novo coronelismo urbano tenha se caracterizado mais pela continuidade do que pela ruptura em relação ao velho coronelismo rural, o que realmente mudou foram os próprios coronéis, que antes eram representados pelos fazendeiros proprietários de terras 
e agora são representados pelos donos das empresas de colonização. Mudaram os personagens e a forma de dominação política, mas continuou a natureza e a essência do poder coronelista. O que se estabelece agora, com o novo coronelismo, é uma relação de compromisso, por um lado, entre o poder político estadual e os coronéis, donos das companhias colonizadoras e, por outro, entre estes e os colonos migrantes, com quem tinham uma relação de clientelismo e paternalismo. Efetivamente, o novo coronelismo estrutura-se a partir da implementação do projeto colonizador.

Na República Velha, a exemplo do que se passava no restante do Brasil, no Oeste catarinense prevalece a violência armada e a coerção na luta pelo poder local. (HASS, 2001). Mas, a partir da década de 1920, com a afirmação do novo coronelismo, o seu mandonismo expressa-se no clientelismo e assume novos fundamentos, com o avanço do Projeto Colonizador, que associava interesses do poder político estadual, das empresas colonizadoras e destas com os colonos migrantes, vistos como os novos "desbravadores do Oeste". Os donos dessas empresas exerciam certo paternalismo em relação aos colonos, os quais permaneciam subordinados aos favores dos colonizadores, legitimando a coação política que exerciam sobre os colonos. A estratégia de colonização da região envolvia uma aliança entre o poder estadual e as empresas colonizadoras. Elas recebiam terras e favores do poder político estadual e realizavam obras públicas, como estradas, pontes e escolas, serviços usados para abater as dívidas pela aquisição das terras. Assim, é em torno do projeto colonizador que se unem os interesses econômicos e políticos e, também, o projeto de dominação eleitoral sobre as bases da migração. Numa época em que a presença e a proteção efetiva do Estado eram insignificantes ou inexistentes, a população ficava na dependência dos favores dos coronéis.

No município de Chapecó, entre 1917 e 1931, a política municipal foi comandada de forma autoritária por vários coronéis, como Manoel dos Santos Marinho, Fidêncio Mello e Passos Maia, que governaram o município mais importante da região Oeste, de acordo com o modelo coronelista e a forma caudilhesca, praticando todo tipo de arbítrio, desmando e violência. 
No entanto, o poder político ligado às empresas colonizadoras foi se enfraquecendo, no período de 1930 a 1944, durante o primeiro Governo Vargas, considerando-se que ele procurou aliar-se não aos coronéis tradicionais e sim aos novos coronéis, que não faziam parte da máquina política tradicional. As transformações econômicas e o processo de redemocratização do país, a partir de 1945, provocaram mudanças significativas na estrutura política de Chapecó. Os políticos tradicionais, representantes do Partido Social Democrático (PSD), apesar de perderem espaço para os partidários da União Democrática Nacional (UDN) e do Partido Trabalhista Brasileiro (PTB), continuaram a dominar o cenário político, ao longo do período de 1947 a 1965. Um dos fatores para o continuísmo das elites tradicionais foi o controle dos cargos públicos e dos votos, através da prática clientelista, estratégia política adotada para a manutenção do poder local. Mesmo assim, o sistema de poder não se alterou substancialmente. Entre 1931 e 1945, o município de Chapecó foi governado por dez prefeitos nomeados e apenas um eleito. A partir de 1945, os coronéis modernos representados pelas empresas colonizadoras e aliados politicamente ao PSD, começaram a perder poder para novos atores econômicos e políticos, oriundos de segmentos urbano-industriais e profissionais liberais, que se vinculavam ao PTB e à UDN. Entre 1945 e 1965, alternam-se no poder o PSD e o PTB, muitas vezes coligados através da Aliança Social Trabalhista (AST).

Efetivamente, o mandonismo foi perdendo força mesmo antes de 1945, com o governo Vargas. Seu declínio acentua-se com a redemocratização pós-1945. O poder local vai se fragmentando. Observa-se a ascensão política de extratos urbanos, compostos de profissionais liberais, funcionários burocráticos, filiados à UDN e ao PTB, que a partir de 1950, passam a ameaçar o domínio do poder local e a pressionar por mudanças na dinâmica política eleitoral e pela abertura de espaço para a participação dos novos atores no quadro político.

As mudanças nas forças políticas locais refletem tanto as mudanças da estrutura econômica e social, como as composições do jogo do poder em nível estadual e federal. A transição, no entanto, não foi pacífica, e sim violenta, marcada por acirrados conflitos políticos 
partidários, que incluíam perseguição política a adversários, coação a eleitores, desmandos administrativos, corrupção e aprovação de leis para atender interesses particulares.

Com o passar do tempo, os acirrados conflitos políticos do início da transição foram substituídos por negociações, que traduziam certo enfraquecimento do predomínio do PSD no âmbito da AST. A perda de poder estadual do PSD também o enfraqueceu regionalmente, uma vez que seus desmandos não podiam mais ser tolerados. A diversificação partidária veio no contexto da maior complexidade da sociedade chapecoense, que se intensifica a partir dos anos 1930, com maior industrialização, expansão do comércio, urbanização e novos meios de comunicação de massa.

No período do regime militar, de modo geral, o poder político local foi ocupado por forças políticas liberais, conservadoras e autoritárias, associadas aos interesses agroindustriais dominantes na região a partir dos anos 1950, todas elas abrigadas na Aliança Renovadora Nacional (ARENA) (HAAS, 2015). O MDB, nas eleições municipais de Chapecó de 1969, embora tenha conseguido eleger seu candidato, Sadi de Marco, não conseguiu governar, pois o prefeito eleito foi cassado, em abril do mesmo ano.

\section{REFERENNCIAS}

HASS, Monica. Os partidos políticos e a elite chapecoense: um estudo do poder local 1945-1965. Chapecó: Argos, 2001. 1999.

O linchamento que muitos querem esquecer. Chapecó: Argos,

Do coronelismo tradicional ao novo coronelismo: reflexões a partir do cenário político e social do oeste de Santa Catarina. In: RADIN, José Carlos; VALENTINI, Delmir José e ZARTH, Paulo A. História da Fronteira Sul. Porto Alegre: Letra e Vida, 2015. THOMÉ, Nilson. A Escola Pública na Região do Contestado: do coronelismo ao advento do neocoronelismo. II Jornada do HISTEDBER Região Sul (Comunicação). Curitiba: outubro/ 2002. 


\section{Formação social}

Uma formação social expressa as características constitutivas próprias de uma determinada sociedade, em termos de suas relações de propriedade e de trabalho, seus laços de solidariedade e coesão, sua visão de mundo, suas crenças e costumes, bem como suas contradições e conflitos internos, sem desconsiderar a influência dos fatores externos à mesma formação social. De modo geral, pode-se dizer que tanto o processo de constituição como o de mudança de uma determinada formação social são influenciados mais fortemente pelos fatores internos do que pelos externos. Ressalte-se que, no caso da sociedade indígena e possivelmente também da cabocla, os fatores externos assumem um papel talvez mais importante do que os internos. De modo geral, também são os fatores de ordem econômica internos à ordem social que possuem força explicativa preponderante sobre outros fatores de ordem política, cultural ou simbólica. Por isso, uma formação social de uma região constrói-se em estreita relação com a sua formação econômica, embora não possa ser explicada única e exclusivamente pelos fatores econômicos, nem pelos fatores internos. Outros fatores de ordem cultural, religiosa ou simbólica devem também ser levados em conta, especialmente em relação às sociedades indígenas.

No caso do Oeste catarinense, analisar a formação social significa caracterizar as diversas classes, camadas ou estratos sociais, bem como as identidades dos povos que habitaram ou ainda habitam a região, no período de sua formação socioeconômica, política e cultural. Tendo como ponto de partida as sociedades indígenas, na sua especificidade e complexidade, seus diversos povos, costumes, crenças, concepções de vida e visões de mundo, esta formação social regional resultou da combinação de elementos da formação social cabocla e colonial, que evoluíram na direção de uma formação social preponderantemente capitalista.

As sociedades indígenas, que habitavam o território do Oeste desde tempos imemoriais, e a cabocla, formada por luso-brasileiros, que adentraram a região principalmente a partir da primeira metade 
do século XIX, mantiveram seus traços originais até aproximadamente 1930, quando se intensificou o processo de colonização. Com o avanço desse processo passa a constituir-se a formação social colonial, que mescla traços das formações sociais anteriores, com traços de uma sociedade familiar capitalista. Uma terceira formação pode ser denominada de formação social capitalista, que acompanha a origem e o desenvolvimento do complexo agroindustrial. Nos períodos de transição, mesclam-se elementos da antiga e da nova formação social, quando os traços da antiga ainda não desapareceram e os da nova ainda não se tornaram dominantes.

Em síntese, pode-se dizer que, a partir de características herdadas das sociedades indígenas, a formação social cabocla caracteriza-se por seus traços nitidamente não capitalistas. Já a formação social colonial mescla traços de uma formação social familiar, com traços de uma formação social capitalista, a qual, embora carregue características de uma agricultura familiar de subsistência, é marcada por aspectos tipicamente capitalistas.

A formação social cabocla constitui-se na região a partir de meados do século XIX, quando deixa de ser preponderante a ocupação indígena e "o contingente populacional predominante era de luso-brasileiros, denominados caboclos" (POLI, 1995). Os povos caboclos do "sertão catarinense" viviam isolados no interior das fazendas e das matas e se dedicavam à extração da erva-mate, ao tropeirismo e à roça cabocla. A sociedade cabocla, seu modo de vida e de trabalho, era dominada por um "ethos comunitário", cimentado pelos valores da igualdade e da solidariedade e estava organizada com base na posse de pequenos lotes de terra e numa economia de subsistência, sem fins mercantis e sem moeda; vivia em pequenas comunidades, nos campos e interior das matas, em harmonia com a natureza (EIDT;TEDESCO, 2012). Essa sociedade, mesmo sendo a mais representativa da região, situava-se à margem da sociedade dominante, pois o caboclo servia de mão de obra barata para fazendeiros, ervateiros e madeireiros. Desprovidos da propriedade estável da terra, pois detinham apenas a posse temporária de pequenos lotes, a sobrevivência dos caboclos dependia do cultivo de suas roças e do serviço que prestavam na extração da 
erva-mate e nas fazendas. Essa era a frágil base econômica daquela formação social pobre, itinerante e discriminada socialmente. Essa formação social cabocla começa a mudar com o processo de colonização, o qual acarretou não apenas mudanças, mas o próprio aniquilamento das formações sociais existentes dos povos indígenas e caboclos.

A formação social colonial origina-se e consolida-se ao longo do processo de colonização da região. Embora movida por fins mercantis, a colonização, ao introduzir a pequena propriedade familiar, carregava consigo um profundo sentimento coletivo, comunitário e religioso, uma espécie de condição necessária para a sobrevivência da própria formação social, face à quase ausência de proteção do Estado. A colonização modifica as próprias relações sociais, relações de propriedade e de trabalho, bem como os valores culturais vigentes na formação social cabocla, com implicações no modo de vida, no lazer, no trabalho, no uso da terra e no cotidiano dos colonos. A colonização muda o objetivo da produção familiar colonial, que além da subsistência, se organiza para o mercado. A produção colonial, embora voltada para a subsistência familiar, foi se integrando progressivamente ao mercado capitalista, mesmo que ainda mantivesse uma considerável parcela de autonomia em relação ao mercado. Por algum tempo, a formação social colonial conseguiu combinar o ethos do trabalho, que carregava no seu interior a ambição da riqueza, com um ethos comunitário, que a mantinha afastada do mercado. Além desse espírito comunitário e vivência em comunidade, em torno da qual se organizava boa parte da vida social e cultural, o que também dava autonomia em relação ao mercado era, entre outros, a prática de seleção das sementes no âmbito da propriedade, a não utilização de fertilizantes químicos, a prática do abate de animais e a troca de carne entre os vizinhos. Com efeito, a formação social colonial se fez na base da propriedade familiar e da produção de subsistência, embora em um contexto econômico tipicamente capitalista. Ou seja, tanto o trabalho como a produção se organizavam na forma familiar de propriedade dos meios de produção, mas se inseriam cada vez mais na lógica de uma economia de mercado.

A formação social capitalista origina-se e consolida-se no Oeste catarinense a partir de meados do século XX, tendo como base 
principal a evolução da formação social colonial. Mais precisamente, a partir da década de 1970, a evolução da organização econômica começou a produzir uma ruptura nesse modelo de organização familiar da propriedade e da produção de subsistência, que caracterizavam a formação social colonial através da formação dos complexos agroindustriais, que transformaram aquele espaço, rompendo a sociabilidade tradicional e integrando a região aos circuitos internacionais da produção, do comércio e das finanças capitalistas. Com a inserção da agricultura familiar no complexo agroindustrial, o espaço regional do Oeste abriu-se e fortaleceu seus laços externos, integrando as atividades locais em cadeias globais. Em consequência, a entrada mais agressiva do capitalismo na região rompeu com os laços de solidariedade que soldavam até então o tecido social da família colonial (EIDT;TEDESCO, 2012). O avanço do capitalismo carregou também a modernização da vida, dos costumes e dos valores, modificando as relações sociais no campo. Os trabalhadores, que antes se valiam dos seus próprios meios de trabalho para produzir sua subsistência, agora ficam subordinados à lógica de acumulação e valorização capitalista. O surgimento das grandes empresas capitalistas, além de modernizar as atividades agrícolas, também mudou drasticamente a forma de vida da sociedade colonial. O aumento da competitividade destroçou antigas solidariedades horizontais e implantou a verticalidade nas relações de trabalho, transformando filhos de antigos camponeses em operários das agroindústrias, no interior dos frigoríficos. Mas o processo de transformação não terminou aí, pois mesmo os colonos remanescentes da agricultura familiar que se transformaram em empresários rurais viram sua antiga autonomia subordinada às regras da racionalidade capitalista. Mudaram seus antigos hábitos, valores e comportamentos, que passaram a ser ditados pela nova sociedade de consumo. As mudanças na organização econômica acabaram por afetar a própria identidade social dos agricultores e o habitus camponês da região Oeste catarinense.

No entanto, a crescente subordinação da economia camponesa à lógica do mercado não foi suficiente, por si só, para determinar as profundas transformações do mundo rural, sem que outros fatores 
de ordem cultural tivessem contribuído para enfraquecer a autonomia dos camponeses e sua escala de valores. Sem a contribuição desses fatores culturais, seria difícil explicar que, num lapso de tempo tão curto, se processassem mudanças tão acentuadas nos valores e forma de vida da formação social colonial (EIDT;TEDESCO, 2012). Com efeito, a partir da década de 1970, e mais fortemente nos anos 1980 e 1990, o complexo agroindustrial se fortaleceu e aprofundou a integração da agricultura familiar, rompendo o equilíbrio e subordinando cada vez mais os agricultores aos métodos e à lógica produtiva capitalista. Como resultado, muitos agricultores foram excluídos do próprio circuito produtivo.

O desenvolvimento do capitalismo nessa região trouxe profundas mudanças na formação social regional, através das quais a formação social colonial passa a assumir características típicas de uma formação social capitalista. Nesse processo, ocorre o enfraquecimento da economia de subsistência e o rompimento dos antigos métodos de exploração do território e do trabalho, bem como o progressivo extermínio dos povos indígenas e a marginalização dos caboclos, que habitavam aquele território durante longos períodos de tempo. Ao mesmo tempo em que se instaura e se consolida o capitalismo, processa-se e aprofunda-se a integração da economia regional na economia nacional e internacional.

\section{REFERÊNCIAS}

EIDT, Paulino; TEDESCO, Anderson L. A Transformação do Ethos no

Oeste de Santa Catarina. IX Anped Sul. Caxias do Sul, 2012.

MELLO, Márcio Antônio. Transformações sociais recentes no espaço rural do Oeste de Santa Catarina: migração, sucessão e celibato. XLIV

Congresso da SOBER. Fortaleza, 2006.

RADIN, José Carlos. Representações da Colonização. Chapecó: Argos, 2009. RENK, Arlene. A Colonização do oeste catarinense: as representações dos brasileiros. In: CEOM. Para uma história do Oeste Catarinense: 10 anos de CEOM. Chapecó: UNOESC, 1995. 


\section{Formação de capital}

A formação/acumulação inicial de um estoque de capital é de fundamental importância para o desenvolvimento econômico e social de uma região. A origem e a evolução histórica da formação/acumulação de capital variam de acordo com a situação e as circunstâncias históricas de cada região. Não há um padrão universal que se repete em todos os tempos e lugares.

No Oeste catarinense, a formação/acumulação de capital se deu progressivamente a partir da evolução das atividades econômicas que ali se desenvolveram. De certa forma ela acompanha a sucessão dos ciclos econômicos, que marcam a história desta região, de acordo com a importância relativa de cada um deles na economia regional.

Por razões diversas, os três primeiros ciclos, o da pecuária, da erva-mate e da madeira, pouco contribuíram para a formação inicial do capital da região. O início deste processo de acumulação de capital só aconteceu a partir do projeto de colonização, onde se desenvolveram a agricultura familiar e a criação de suínos com fins comerciais. A formação do capital comercial e sua posterior transformação em capital industrial comandaram o processo de desenvolvimento da região Oeste catarinense. Foi a partir da agricultura familiar, especialmente através da criação e comercialização de suínos, que se formou o capital comercial, fonte da acumulação inicial e do desenvolvimento capitalista da região. Antes da criação e comercialização de suínos, nem as atividades da pecuária ou as da erva-mate, nem mesmo a indústria madeireira, foram fontes de acumulação de capital para a região, exceção feita a algumas pequenas serrarias, ali instaladas, mais com o objetivo de suprir as necessidades locais dos colonos do que para fins comerciais. Já as grandes madeireiras desmatavam e beneficiavam a madeira, visando unicamente sua exportação e, do mesmo modo que a madeira, também enviavam seus lucros para fora da região, deixando de contribuir para o seu desenvolvimento econômico. Em algumas colônias, sobretudo alemãs, a cultura do fumo teve papel importante na formação de uma renda extra para os agricultores. 
Mas o capital começou mesmo a ser acumulado a partir da venda de terras pelas companhias colonizadoras e especialmente da criação e do comércio de suínos pelos colonos procedentes do Rio Grande do Sul (GOULARTI FILHO, 2007).

Foi no âmbito da agricultura familiar que a criação de suínos se afirmou com grande potencial de desenvolvimento. Aos poucos, essa atividade foi deixando de produzir apenas para a subsistência dos colonos e se transformou na sua principal atividade comercial. Embora o objetivo maior fosse a produção para o autoconsumo familiar, a comercialização do excedente colonial, agrícola e pecuário se desenvolve de modo que aos poucos a produção para o comércio foi se tornando dominante e se afirmando como um novo e principal objetivo da produção agrícola familiar.

Inicialmente, os agricultores criavam suínos comuns, tipo banha, soltos, alimentados com produtos oriundos da propriedade do agricultor, cujo abate se dava, em média, após quatorze meses de vida. A produção da banha suína, e não a da carne, devido as suas peculiaridades de conservação, foi se transformando num dos principais produtos de valor comercial capaz de gerar alguma renda excedente ao consumo para colonos e comerciantes. Sua produção alimentava uma rede de comercialização formada pelas casas comerciais situadas em pontos-chave das áreas coloniais da região. Depois, progressivamente, foram sendo introduzidas novas raças, cuja criação exigia dos agricultores um novo padrão técnico, como o confinamento dos animais, maiores cuidados sanitários, rações mais elaboradas, o que acarretou o aumento de produtividade. Assim, o período de terminação dos suínos foi se encurtando progressivamente até chegar à média atual de apenas seis meses.

Nos primeiros tempos, ainda na década de 1930, algum excedente dessa produção começava a ser comercializado nas "vendas", ou pequenas casas comerciais da região, mas, à medida que o excedente passou a ser mais expressivo, sua comercialização se amplia para além do pequeno comércio local, atingindo outros centros consumidores do país, como São Paulo, Rio de Janeiro e Rio Grande do Sul. Os comerciantes ampliam suas compras dos agricultores, fornecendo em 
troca produtos mais elaborados, como tecido em metro, querosene, sal, ferramentas agrícolas e outros produtos industrializados, criando-se uma maior relação de dependência entre agricultores e comerciantes. Com o desenvolvimento do comércio, amplia-se também o papel econômico-comercial, comunitário e mesmo político do comerciante. Aos poucos, ele vai se tornando uma figura indispensável para o desenvolvimento das atividades econômicas da região. Efetivamente, a partir de suas atividades comerciais, o comerciante tinha uma grande ascendência sobre os colonos, dado seu poder de persuasão e seu maior conhecimento sobre os mais variados temas, que iam desde a prática agrícola, à economia financeira e, também, sobre a orientação político-partidária.

É através desse processo que o desenvolvimento do capital comercial vai provocar sua própria transformação em capital industrial, à medida que começa a ser investido no abate dos animais e no processamento da carne suína. Inicialmente, o suíno era levado vivo para São Paulo. Mas, na medida em que este comércio deixou de ser rentável, foram gradativamente surgindo pequenos abatedouros locais destinados à produção e comercialização da carne suína. Nos anos 1940 e 1950, esses abatedouros vão se transformando em pequenos frigoríficos dedicados, primeiro, ao processamento da banha e, depois, com a chegada da luz elétrica e as câmaras frigoríficas, passam também a processar a carne suína (MIOR, 2005). Foi assim, a partir do capital comercial, coadjuvado pela renda dos pequenos agricultores, que se formaram os primeiros abatedouros e frigoríficos, através dos quais se deu a transformação do capital comercial em capital industrial. Nesse processo de transformação, aos poucos, com o desenvolvimento dos próprios frigoríficos, tanto comerciantes como agricultores vão se tornando figuras secundárias, até desaparecerem completamente com a estruturação do complexo frigorífico e agroindustrial da região. Por algum tempo, ainda, o comerciante continua como responsável pela coleta e transporte dos suínos, enquanto o frigorífico se ocupa do abate e da venda da produção. E os pequenos agricultores, que, de início, entraram como sócios ou acionistas dos frigoríficos, aos poucos vão sendo excluídos, à medida que o valor de suas cotas de participação 
foi se tornando insignificante. Em um determinado momento, o frigorífico torna-se uma empresa capitalista e o empresário industrial se torna seu único proprietário.

\section{REFERÊNCIAS}

CAMPOS, Índio. Os colonos do Rio Uruguai: relações entre pequena produção e agroindústrias no oeste catarinense. Campina Grande UFPB, 1987 (Dissertação de mestrado).

COLETTI, Tomé. Agroindústria suinícola e agricultura familiar: uma "crônica" sobre a trajetória histórica no Oeste Catarinense. (Dissertação de Mestrado) Florianópolis: UFSC, 2009.

GOULARTI FILHO, Alcides. A Estrada de Ferro São Paulo-Rio Grande na formação econômica regional em Santa Catarina. Florianópolis, Geosul, V. 24, N. 48, 2009.

. Formação Econômica de Santa Catarina. Florianópolis: UFSC, 2007.

MIOR, Luiz Carlos. Agricultores familiares, agroindústrias e redes de desenvolvimento rural. Chapecó: Argos, 2005. 


\section{Guerra do Contestado}

A Guerra do Contestado foi um conflito armado, ocorrido entre outubro de 1912 e agosto de 1916, que confrontou, de um lado, a população sertaneja e, do outro, as forças do governo estadual e federal, em terras do Oeste paranaense e catarinense. A guerra ocorreu num contexto histórico-geográfico e social conturbado por uma série de conflitos, como foi a questão dos limites entre Brasil e Argentina, bem como a disputa das terras contestadas entre os estados de Santa Catarina e do Paraná, além da expropriação das terras e expulsão da população cabocla, que vivia na região. Some-se a isso o coronelismo dominante na região, o impacto e as consequências da construção da estrada de ferro São Paulo-Rio Grande, que expropriou terras e deslocou milhares de sertanejos, e a herança de conflitos ligados principalmente à Revolução Federalista de 1893, que impactou fortemente o planalto catarinense. A pregação religiosa e social dos monges também contribuiu como elemento catalisador do descontentamento e da revolta dos sertanejos, fazendo-a tomar forma de uma "guerra santa". Somado a esse conjunto de problemas sociais, decorrentes principalmente da falta de regularização da posse de terras e da insatisfação da população da região, está a quase inexistência do poder público na região.

A tropa oficial envolvida na guerra chegou a ter 7 mil pessoas, as quais representavam mais de um terço do exército republicano brasileiro, além de policiais de Santa Catarina e do Paraná e capangas arregimentados pelos fazendeiros. Pela primeira vez, também, na América do Sul, foi utilizada a aviação com fins bélicos. Do outro lado, o contingente das forças rebeldes chegava a somar milhares de combatentes, variando de acordo com as circunstâncias. O total de mortos em consequência dos combates, da fome e das epidemias pode ter sido superior a 10 mil. (MACHADO, 2012). O fim do conflito foi selado pelo Acordo dos Limites, presidido pelo Presidente da República, Wenceslau Brás, e assinado em 20 de outubro de 1916 pelos governadores de Santa Catarina, Felipe Schmidt, e do Paraná, Afonso Camargo. 
Na comunidade de Taquaruçu, um grupo de sertanejos reunidos em torno do monge José Maria, ao ser perseguido pela polícia catarinense, refugiou-se na localidade de Irani, ao Oeste, em território reivindicado pelo Paraná, cujas autoridades consideraram uma invasão catarinense em seu território. $\mathrm{O}$ ataque da polícia paranaense ao grupo de sertanejos, em 22 de outubro de 1912, ficou conhecido como a Batalha do Irani, a qual marcou o início da Guerra do Contestado. Nessa batalha morreram 11 sertanejos, inclusive o monge José Maria, e 10 soldados, incluindo o comandante das forças paranaenses, João Gualberto Gomes de Sá.

A Batalha do Irani foi considerada como uma primeira vitória contra as forças governamentais. Para os sertanejos, o monge José Maria, símbolo da luta pela posse da terra, não morreu, ele continua encantado no meio do povo. A crença de que ele voltaria para guiar seu povo até a vitória final passou a alimentar o reagrupamento da população sertaneja. Um ano depois da morte do monge, a menina Teodora, de 11 anos, passou a ter visões e a receber mensagens do monge, que pedia para seus seguidores se reunirem em Taquaruçu. O agrupamento efetivo inicia em dezembro de 1913 e transforma-se em uma "cidade santa”. A partir do exemplo de Taquaruçu, formaram-se inúmeras outras "cidades santas", como Caraguatá, Santo Antônio e Santa Maria, a maior delas, que chegou a reunir mais de 20 mil pessoas. As "cidades santas" eram verdadeiras comunidades que se transformaram em fortes redutos sertanejos. Em muitas delas, chegou-se mesmo a organizar alguma forma de "comunismo caboclo".

No início de 1914, tropas conjuntas de Santa Catarina, Paraná e do governo federal, com um efetivo de 700 soldados, atacam o reduto de Taquaruçu, incendeiam o acampamento, mas os sertanejos fogem e se refugiam no acampamento de Caraguatá. Esse reduto se formou sob a liderança de Maria Rosa, uma jovem de quinze anos, que a exemplo da menina Teodora, também dizia ter visões e receber mensagens do monge. Maria Rosa é considerada por muitos como uma Joana D'Arc sertaneja. Em 9 de março de 1914, as tropas oficiais cercam e atacam Caraguatá, mas são derrotadas pelos caboclos. A vitória atrai novos caboclos para o reduto e reforça a luta contra as tropas oficiais. A partir 
daí os sertanejos partem para a ofensiva, saqueando fazendas de coronéis e atacando cidades, numa espécie de "guerra santa". No ataque a Curitibanos, um dos alvos foram os cartórios onde se encontravam os registros das terras que estavam em posse dos caboclos e lhes haviam sido tiradas. Na localidade de Calmon, foi incendiada e destruída uma serraria da Lumber, um dos símbolos da presença estrangeira na região. O governo federal mostrava-se cada vez mais preocupado com a dimensão da revolta sertaneja e o clima de guerra que tomava conta da região. O general Mesquita, veterano de Canudos, é nomeado para comandar as ações contra os rebeldes. $\mathrm{O}$ ataque ao reduto de Santo Antônio e uma epidemia de tifo no reduto de Caraguatá obrigam os revoltosos a fugirem e a se dispersarem. No entanto, os sertanejos voltam a reorganizar-se na localidade de Santa Maria. O comandante das forças oficiais tinha ordens para sufocar a rebelião e pacificar a região a qualquer custo, mas, em vez do ataque direto, ele adota a estratégia de cercar os redutos e cortar o abastecimento, na expectativa de conseguir a rendição dos rebelados. É nessas circunstâncias que começa a destacar-se a figura e a liderança de Deodato Manuel Ramos, mais conhecido por Adeodato, considerado pelos historiadores como o último líder dos sertanejos. Adeodato transfere o núcleo dos revoltosos para o vale de Santa Maria, que chega a reunir mais de 20 mil pessoas. Com o aperto do cerco aos rebeldes, os problemas internos agravam-se e eles não podem resistir por muito tempo. Nos primeiros meses de 1915, são feitos diversos ataques ao reduto de Santa Maria e a outros agrupamentos. Em dezembro de 1915, todos os redutos rebeldes haviam sido destruídos, mas o final da guerra só se efetiva de fato com o término do litígio dos limites entre Paraná e Santa Catarina, em 20 de outubro de 1916.

Parte da imprensa, setores governamentais e a opinião pública da época apontaram como causa do conflito a ignorância e o fanatismo da população cabocla, que seguia a orientação do monge José Maria (WELTER, 2007). Depois da batalha de Taquaruçu, em fevereiro de 1914, o movimento chegou mesmo a ser denominado de banditismo, jaguncismo e fanatismo. No entanto, as razões da guerra foram mais amplas e complexas. Tratava-se de um verdadeiro movimento social 
(MACHADO, 2001) ou mesmo do "maior conflito social brasileiro envolvendo questões fundiárias" (VALENTINI, 2015). Embora tenha começado como um fenômeno religioso, de exaltação milenar, com fortes características messiânicas e místicas, associadas à morte de seu principal líder, o monge José Maria, e à crença na sua volta, esse movimento reuniu diferentes segmentos sociais, como posseiros, sitiantes expulsos de suas terras, comunidades negras e caboclas, ervateiros, desempregados da estrada de ferro, médios fazendeiros, antigas lideranças federalistas e opositores dos coronéis.

Esse conflito armado tem duas faces, uma "guerra santa", de um lado, e uma "guerra sertaneja", de outro. Ou seja, uma face religiosa, messiânica e mística e outra face crítica e social, as quais tiveram pesos variáveis, dependendo das circunstâncias. Mesmo que o discurso oficial tenha sido a "guerra santa", linguagem geral da rebelião, o motivo religioso não esgotava as razões da guerra, pois os sertanejos tinham plena consciência contra quais forças estavam lutando. Seus alvos eram os chefes políticos locais, os grandes fazendeiros, os interesses estrangeiros e a marginalização sertaneja. Os sertanejos desenvolveram "uma nítida consciência das condições sociais e políticas de sua marginalização" (MACHADO, 2001). Para eles, tratava-se de uma "guerra entre ricos e pobres", que lutavam contra um governo que "defendia os interesses dos endinheirados, dos coronéis e dos estrangeiros".

O nome "contestado" está relacionado a vários fatos, como a contestação de caboclos e agricultores pelo fato de suas terras terem sido apropriadas pelas madeireiras, como foi o caso da Lumber, pelas terras serem disputadas, primeiro pelo Brasil e Argentina e depois pelos estados do Paraná e de Santa Catarina. Embora o conflito tenha se travado na sua maior parte em terras catarinenses não contestadas, ele ficou consagrado, inicialmente, pelos relatos militares e depois pela maior parte da literatura como Guerra do Contestado. Mas o conflito dos limites entre os estados do Paraná e de Santa Catarina e suas reivindicações pelo "território contestado" não influíram senão indiretamente na Guerra do Contestado. Para Machado (2001), o nome mais adequado seria "Guerra Sertaneja do Contestado". 
Outra questão se refere à defesa da monarquia feita pelo movimento sertanejo rebelde. Como muitos outros movimentos sociais rurais brasileiros, o movimento sertanejo rebelde do Contestado também fez a defesa do regime monárquico de governo. Uma espécie de "monarquismo sertanejo" passou a fazer parte dos objetivos dos seguidores do monge José Maria. Uma das razões para a exaltação do regime monárquico foi que muitos dos males vividos pelos sertanejos da região atingida pela guerra eram atribuídos ao regime e às políticas do governo republicano. Os sertanejos desamparados pelo governo republicano pareciam sentir uma proteção paternal do monarca. Para eles, a Monarquia era uma forma divina superior de organização social. A Monarquia é vista como o regime da "lei de Deus", e a República é associada à lei do diabo e ao poder dos coronéis.

Por longo tempo, a Guerra do Contestado permaneceu no esquecimento. Os relatos militares foram sua principal memória, até que, nas décadas de 1960 e 1970, o tema se tornou objeto de inúmeras pesquisas acadêmicas. $O$ trabalho de Valentini (2015) oferece uma ampla e diversificada bibliografia sobre aquele que foi talvez o maior conflito social e bélico travado no Brasil.

\section{REFERENCIAS}

KARSBURG, Alexandre de Oliveira. O Eremita do Novo Mundo: A trajetória de um peregrino italiano na América do século XIX (1838-1869). (Tese de Doutorado) Rio de Janeiro: UFRJ, 2012.

MACHADO, Paulo P. Um Estudo Sobre as Origens Sociais e a Formação Política das Lideranças Sertanejas do Contestado, 1912 - 1916. (Tese de Doutorado) Campinas: Unicamp/História, 2001. . Guerra do Contestado: os reflexos cem anos depois. Entrevista.

Revista IHU, São Leopoldo: Unisinos, 15 de outubro de 2012.

VALENTINI, Delmir José. A Guerra do Contestado (1912-1916). In:

RADIN, J.C; VALENTINI, D. J.; ZARTH, P. A. História da Fronteira Sul. Porto Alegre: Letra e Vida, 2015.

WELTER, Tânia. O Profeta São João Maria continua encantando no meio do povo: um estudo sobre os discursos contemporâneos a respeito de João Maria em Santa Catarina(Tese de Doutorado). Florianópolis: UFSC, 2007. 


\section{Índio Condá}

Vitorino Condá nasceu nos campos de Guarapuava, em 1805, e morreu em sua aldeia nas margens do Rio Chapecó, nos campos de Palmas, em 1870, com 65 anos de idade. Foi cacique da tribo Kaingang, um importante líder indígena, que se notabilizou durante o processo de ocupação das terras indígenas do Oeste catarinense por fazendeiros e autoridades imperiais, principalmente a partir de meados do Século XIX.

A ocupação do território Kaingang causou muita tensão e conflito na região. A frente pastoril de ocupação, apoiada pelas autoridades imperiais, praticava uma verdadeira política de extermínio contra os indígenas, mas ao mesmo tempo procurava aliciar os que eram dóceis e estavam dispostos a colaborar com o processo de ocupação. Assim, a referida ocupação dividiu o povo indígena entre os favoráveis e os contrários a uma aliança com os brancos, que manipulavam as divisões internas dos indígenas para consolidarem a tomada do território. Condá tinha uma grande ascendência sobre os demais caciques e os diversos grupos Kaingang (RIESEMBERG, 1978) e, como tal, se transformou numa peça-chave do processo de conquista do Oeste, nos Campos de Palmas.

$\mathrm{Na}$ realidade, os povos indígenas não tinham muitas alternativas. Podiam fugir de suas terras, abandonando tudo o que era seu, resistir, serem escravizados ou simplesmente eliminados, ou ainda aceitar a ocupação e integrar-se na nova situação, aldeando-se em vilas como queriam os invasores. Na luta de resistência, eram comuns os sequestros tanto de índios como de fazendeiros. Conta-se que, em 1843, Condá foi instado pelo comandante da Polícia em Palmas a ajudar no resgate do tropeiro capitão José de Sá Soutto-Maior das mãos de indígenas que habitavam as proximidades.

Foi nesse contexto de invasão, conflito e extermínio que se destacou o papel do cacique Condá. Como superar o dilema do seu povo de resistir e ser eliminado ou fazer acordo com os invasores e tentar sobreviver? Condá operou nesta trama bastante complexa. Ele atuava 
mais como peça de uma grande engrenagem, movida por interesses muito poderosos. As múltiplas facetas do papel de Vitorino Condá só são compreensíveis se for levada em conta a correlação de forças entre governantes, povoadores locais e os próprios indígenas. As relações de poder eram muito desiguais e os interesses recíprocos bastante diversos. Os povos indígenas eram o elo mais fraco numa guerra para manter suas terras e salvar suas vidas. Ao governo interessava fortalecer a ocupação de um território de fronteira em disputa com a Argentina e Condá era uma peça chave de permanência brasileira nos Campos de Palmas (D’ANGELIS, 2006). Já aos brancos invasores interessava a apropriação das terras indígenas, valendo-se ao mesmo tempo do conhecimento do território e da experiência dos caciques para "pacificar" índios e fazê-los aceitar a ocupação e a convivência com os invasores.

É nesse contexto que se pode compreender a posição ambígua, controversa e até contraditória de Condá, que oscilava entre a colaboração e a hostilidade, dependendo da situação, muitas vezes até lutando contra seus próprios companheiros indígenas, conforme o jogo de interesses que permeavam as posições de cada parte. O próprio Condá às vezes era tratado pelas autoridades policiais da região como assassino e assaltante e outras vezes como pacificador e colaborador. Segundo algumas versões, Condá teria aceitado a ocupação, colaborando no aldeamento dos indígenas durante o processo de ocupação de suas terras. Para Santos (1970), não resta dúvida que Condá havia aceitado a convivência pacífica com os fazendeiros em Guarapuava. Seu papel colaboracionista ficará marcado no apoio à penetração brasileira nos Campos de Palmas e, em seguida, de Nonoai, no Rio Grande do Sul. No entanto, segundo outras versões, a colaboração de Condá teria sido apenas uma estratégia de sobrevivência, face ao poderio do invasor. Como afirma Mota (2000), a colaboração com os brancos não significava que os índios fossem totalmente submissos e confiáveis.

Enfim, para avaliar o papel do cacique Condá, é preciso levar em conta esse contexto complicado em que estava inserido e a trama de interesses em que fora envolvido pelas autoridades e pelos colonizadores. As atitudes de Condá em geral eram bem-vistas por parte do governo. 


\section{REFERÊNCIAS}

D'ANGELIS, Wilmar da Rocha. Para uma história dos índios do oeste catarinense. CEOM: 20 anos de memórias e histórias no oeste de Santa Catarina. Cadernos do CEOM, Ano 19, n. 23 Chapecó: Unochapecó, 2006. MALAGE, Kátia Graciela J. M. Condá e Viri: chefias indígenas em PalmasPR, década de 1840. (Dissertação de Mestrado). Curitiba: UFPR, 2010. MOTA, Lúcio Taudeu. Os índios Kaingang e seus territórios nos campos do Brasil meridional na metade do século passado. In: MOTA, Lúcio Tadeu; NOELLI, Francisco S.; TOMMASINO, Kimiye (Org.). Uri e Wãxi: estudos interdisciplinares Kaingang. Londrina: UEL, 2000. RIESEMBERG, Alvir. A nau São Sebastião. Instituto Histórico, Geográfico e Etnográfico Paranaense. Curitiba, 1978.

SANTOS, Sílvio Coelho dos. A integração do índio na sociedade regional: a função dos postos indígenas em Santa Catarina. Florianópolis: UFSC, 1970. 


\section{Linchamento de 1950}

Um linchamento pode ser entendido como uma ação coletiva violenta, com conotação de vingança ou justiça punitiva, em desacordo com a lei e sem julgamento, realizada como punição contra algum suposto praticante de um crime real, que pode ser um simples furto ou um assassinato. Um linchamento é considerado um movimento associado a patologias das multidões. Uma forma de fazer justiça pelas próprias mãos.

O denominado "Linchamento de 1950" aconteceu na noite de 17 para 18 de outubro de 1950, na cidade de Chapecó, quando um grupo de aproximadamente 80 pessoas invadiu a cadeia municipal e assassinou quatro presos, acusados de terem incendiado a igreja local, no dia 4 de outubro de 1950. Os presos, depois de mortos, com tiros, facas e pauladas, foram arrastados para fora das celas, no pátio da cadeia, e queimados em praça pública, sob os olhares coniventes de uma pequena multidão. O crime teve enorme repercussão local, nacional e internacional, como noticiaram jornais brasileiros, belgas e franceses. A revista brasileira "O Cruzeiro", de 11 de novembro de 1950, reportou o "bárbaro acontecimento", que projetou Chapecó como uma cidade violenta. O impacto do linchamento dos quatro presos, que marcou profundamente a história da cidade, foi tão forte, que abalou as bases sociais da cidade a tal ponto que durante anos o assunto sequer podia ser comentado na região. As pessoas sentiam-se ameaçadas e estavam receosas em falar do assunto.

Esse trágico acontecimento, ocorrido numa pequena e pacata cidade do interior, não pode ser separado da história da cidade e da região. Chapecó, apesar de seu desenvolvimento urbano, manteve sua característica rural, com o predomínio de famílias tradicionais, oriundas de colonizadores e madeireiros, que davam proteção política aos amigos e perseguiam os inimigos. A dominação tradicional, que se baseava no velho coronelismo rural, assumiu formas novas e mais sofisticadas no novo coronelismo urbano e passou a manifestar-se através 
do clientelismo partidário e do controle dos meios de comunicação (HASS, 1999; 2001).

O Linchamento de 1950 e outros fatos de acentuada violência a ele relacionados podem melhor ser compreendidos a partir do contexto social e econômico e das relações de poder predominantes na região na época do episódio. Sua compreensão reside nos mecanismos de poder subjacentes aos fatos, pois os personagens desse crime estão inseridos na dinâmica das relações sociais e do poder local. O crime esconde uma situação política bem mais complexa do que a que aparece à primeira vista. $\mathrm{O}$ local do crime tinha a marca das relações do poder local e, de alguma forma, o crime não deixava de expressar e ser consequência do mandonismo e do coronelismo político imperante na região, que tinham base na concentração econômica e nas relações de poder a nível estadual. A violência foi uma das características que marcaram a história da Região Oeste catarinense e se expressou tanto através de conflitos de fronteira, como de conflitos políticos e étnicos, que alimentaram o imaginário social desta região violenta. Na verdade, os linchadores não estavam praticando uma ação individual ou de um pequeno grupo apenas, mas um ato coletivo, supostamente em defesa da identidade de uma comunidade e de seus valores básicos, como o ethos do trabalho, a vida de lutas e de sacrifício dos colonos, para os quais esses valores tinham sido violados. Tratava-se de uma sociedade profundamente conservadora e violenta, dominada pelas práticas coronelistas de mando e de poder.

O referido linchamento acontece na pequena e pacata comunidade rural de Chapecó, onde quase todos se conheciam, num momento em que ela começava a dar sinais de mudança nas suas bases políticas. Efetivamente, as eleições de 3 de outubro de 1950 marcaram a ruptura da forma coronelista de dominação política, quando as forças agrárias representadas pelo Partido Social Democrático (PSD) do coronel Bertaso foram derrotadas pela coalizão opositora formada pelo Partido Trabalhista Brasileiro (PTB), pela União Democrática Nacional (UDN) e pelo Partido Social Progressista (PSP), que representavam as novas forças vinculadas, não mais aos interesses agrários e madeireiros, mas às atividades urbano industriais e profissionais liberais. 
Nesse ambiente de mudança social e política, gente nova e diferente começou a circular pela cidade, mas os forasteiros não passavam despercebidos, eram vigiados e vistos com desconfiança. Os olhos do delegado local seguiam todos os passos dessas pessoas "estranhas", que podiam significar uma ameaça à ordem pública local. A ideologia do trabalho estava atenta e vigilante contra pessoas ociosas que andavam pela cidade.

Os colonos, mesmo na condição de pequenos proprietários rurais, dedicados a uma economia de subsistência, estavam inseridos na lógica capitalista e na estrutura política dominante das empresas colonizadoras e das madeireiras. A Igreja, em sua organização hierárquica e nas suas ações, estava integrada na estrutura de poder local e alinhada com a elite, defensora de posições conservadoras. A vida social girava em torno da religião. Para ter-se uma ideia do conservadorismo e do preconceito reinantes na sociedade, basta lembrar que os estatutos do Clube Recreativo Chapecoense proibiam a entrada de negros, em 1950, seis décadas depois da abolição da escravidão.

Naquela época, os incêndios eram muito comuns na cidade. Em 1948, houve o incêndio do Hospital Santo Antônio. Na madrugada da quarta-feira de cinzas de 1950, houve o incêndio no Clube Recreativo, o qual foi atribuído a seu ecônomo, Orlando Lima, que estava vinculado à oposição política. Afirma-se que o delegado regional, um grileiro de terras, pertencente aos quadros do PSD, teria tentado subornar Orlando, pedindo propina para arquivar o processo, mas que Orlando não teria concordado. No entanto, o mais importante daqueles incêndios, que serviu de motivo mais imediato para o linchamento, foi o incêndio da Igreja Matriz, ocorrido no dia 4 de outubro de 1950.

Embora não se saiba a origem precisa do incêndio da igreja, ele foi imediatamente associado à oposição política, que havia vencido as eleições municipais daquele ano de 1950. No entanto, tal incêndio poderia ter-se originado de velas, que sempre eram queimadas dentro da igreja ou mesmo de mendigos, que costumavam aquecer-se à noite com pequenas fogueiras nos arredores da igreja. Talvez o fato mais importante que motivou o linchamento tenha sido o sermão do pároco no dia seguinte ao incêndio, no qual pregava um justo castigo aos 
que haviam incendiado a igreja. Esses malfeitores mereciam também ser queimados, pregava o padre. Imagine-se a força dessa exortação, vinda do próprio vigário, talvez uma autoridade mais importante que o próprio delegado, o prefeito e o juiz da cidade. A voz do padre assumia força de lei, pois se dizia que ele tinha mais poder que o próprio coronel Bertaso. Ao pregar a vingança, o padre "envenenou" o povo, acirrando seu fanatismo.

Quem seriam os culpados? Os acontecimentos desenrolaram-se como descritos a seguir. A suspeita recaiu imediatamente sobre dois forasteiros, desocupados, Romano Ruani e Ivo de Oliveira, que circulavam pela cidade há algum tempo. Eles se hospedavam no mesmo hotel onde também se hospedava Orlando Lima, ecônomo do Clube Recreativo, que havia sofrido incêndio tempos antes. Romano e Ivo foram os primeiros a serem chamados pelo delegado para averiguação. Presos e submetidos a atos de tortura, ambos confessaram terem incendiado a igreja e acusaram Orlando Lima de ser o mentor intelectual do incêndio. Em consequência dessa confissão, Orlando Lima também foi preso. Seu irmão, Armando Lima, que morava em Erechim, ao saber da prisão de Orlando, vai imediatamente a Chapecó para tentar libertar o irmão. No entanto, ao chegar à cidade e tentar libertar o irmão também é preso, por suposta cumplicidade. Enquanto isso, a cidade continuava assustada e temerosa do que poderia vir a acontecer. Criou-se um clima de hostilidade contra os presos e de pressão social para que pessoas indecisas participassem do movimento de vingança. Corriam abaixo-assinados pedindo punição e vingança contra os que haviam incendiado a igreja. Esse movimento era de pleno conhecimento do delegado e das demais autoridades, inclusive das autoridades de segurança do Estado. Não foram poucas as advertências de Roberto Machado, advogado dos presos, alertando para os riscos de vida que corriam seus clientes.

As reuniões das pessoas mais exaltadas sucediam-se em diversos lugares. Organizou-se um intenso trabalho de aliciamento e preparação do ato final de vingança. O último encontro dos vingadores, antes da chacina, foi no pavilhão da igreja incendiada. Uma multidão exaltada, muitos deles embriagados, armados com revólveres, paus, 
facões e foices, investiu contra a cadeia e trucidou os presos e depois arrastou-os para fora das celas e colocou fogo nos seus cadáveres. Eram cerca de oitenta pessoas que, numa espécie de ritual macabro, rodeavam os corpos mutilados e em chamas, festejando e fazendo pilhérias. A força pública tanto se omitiu, como se viu impotente para conter aquela multidão enfurecida.

Dias tensos seguiram-se ao linchamento. Muitos tiveram que esconder-se ou retirar-se da cidade por temor de vingança e perseguição política. O padre, que "pusera fogo na fogueira", sumiu misteriosamente. $\mathrm{O}$ juiz sabia das torturas e omitiu-se, mas ele também tinha medo de acabar preso com os demais. O poder judiciário não conseguia manter a devida independência. A cidade ficou paralisada, acabaram as festas e os bailes. Fecharam-se os cinemas. O linchamento foi a expressão máxima da violência reinante na cidade. Até o projeto de colonização estagnou. As atividades econômicas pararam.

Há indicações de que realmente Ruani e Oliveira seriam os autores do incêndio e eles declararam que os irmãos Lima efetivamente eram inocentes. O julgamento dos autores do crime foi político, em que a comunidade chapecoense uniu-se na defesa de seus valores. $\mathrm{O}$ julgamento foi transferido para a comarca de Porto União e realizado em 12 de setembro de 1952, quase dois anos depois do acontecimento. Das 71 pessoas que foram a julgamento, mais ou menos 40 pessoas foram indiciadas. O delegado foi o primeiro a ser preso e sentenciado por 24 anos de prisão, mas tão logo o PSD voltou ao poder municipal, um novo júri foi organizado e ele foi inocentado por unanimidade. A imprensa local, controlada pelo poder político, noticiou sob medida o ocorrido. As edições do jornal "A Voz de Chapecó”, referentes aos dias do linchamento, sumiram da Biblioteca de Chapecó, numa tentativa de manipular a memória dos fatos, que é outra forma de autoritarismo. Com o linchamento foram eliminadas as pessoas que representavam uma ameaça à ordem estabelecida da cidade.

Aquele linchamento pode ser considerado um dia de fúria no Oeste, que projetou a cidade de Chapecó como um território de bandidos. O banditismo imperava pelos vilarejos e pelas estradas, onde as pessoas andavam armadas, e qualquer desavença poderia terminar em 
briga e morte. A violência também estava presente nas disputas políticas. A fama de território hostil era antiga e vinha desde os tempos da colonização da região. Um crime cercado de manipulações. A chacina não foi caracterizada como linchamento público, porque a participação efetiva no crime foi de poucas pessoas, mas o ato também não foi considerado como livre manifestação popular, por haver indícios de organização e premeditação dos fatos.

\section{REFERÊNCIAS}

HAAS, Monica. Os partidos políticos e a elite chapecoense: um estudo do poder local 1945-1965. Chapecó: Argos, 2001.

. O linchamento que muitos querem esquecer. Chapecó: Argos, 1999.

MARTINS, Jessé de Souza. Linchamentos: a justiça popular no Brasil. Rio de Janeiro: Contexto, 2015. 


\section{Madeireira Lumber}

A Madeireira Lumber, como ficou conhecida, foi a maior e mais impactante da região Oeste catarinense, nas primeiras décadas do século XX. O nome completo da empresa era Southern Brazil Lumber \& Colonization Company. Ela fazia parte do Grupo Farquhard, um conjunto de empresas de origem norte-americana, que atuava em nível mundial em vários ramos de atividades, mas principalmente em ferrovias, portos e navegação. Como seu próprio nome diz, ela era mais propriamente uma empresa de colonização, mas no Oeste catarinense deixou sua marca, sobretudo nas atividades relacionadas à madeira.

A exploração da madeira como atividade econômica nas matas da região começa a ganhar importância, a partir da decadência do ciclo da erva-mate, nas primeiras décadas do século XX. De início, a madeira era explorada de forma artesanal pelos caboclos e colonos, que a beneficiavam através de engenhos de serrar, hidráulicos ou de tração animal, com fins de utilização doméstica. Além do próprio consumo, uma parte da madeira bruta explorada principalmente pelas madeireiras do Oeste, situadas em Chapecó e região, era comercializada, a partir do porto de Goio-En, através do rio Uruguai, durante os períodos de cheia. As toras de madeira eram embarcadas em forma de jangadas e levadas para a Argentina, seu grande mercado consumidor externo. A construção da ferrovia, em 1910, trouxe grande impulso às atividades de beneficiamento e comercialização das madeireiras oriundas do Vale do rio do Peixe e proximidades da ferrovia. Durante a Guerra do Contestado, 1912 a 1916, e Primeira Guerra Mundial, a atividade madeireira voltou a cair, para consolidar-se como atividade econômica dominante, na década de 1920 em diante. No auge do ciclo também era um dos principais itens de exportação catarinense, sobretudo para os mercados do centro do país. Aproximadamente $80 \%$ da produção local de madeira era destinada aos mercados de São Paulo e Rio de Janeiro. O restante da produção seguia para Argentina e Uruguai. $\mathrm{O}$ avanço do processo de colonização também contribui enormemente para a derrubada das matas e para a expansão das atividades 
madeireiras. Ao redor dessas indústrias da madeira, muitos núcleos e vilas foram se formando.

A Lumber estava autorizada a instalar-se na região, desde 1909, mas só começou a operar efetivamente, em 1911, depois de concluídas as obras da estrada de ferro que ligava São Paulo ao Rio Grande do Sul. Para facilitar os trabalhos da madeireira, seu proprietário, Percival Farquhar, mandou construir um ramal ferroviário ligando a madeireira à estação de trem de Porto União, no intuito de facilitar a exploração da madeira ao longo da ferrovia.

A empresa assumiu proporções gigantescas e transformou-se em uma das maiores serrarias da América Latina. Ela chegou a possuir nada menos do que 276 mil alqueires de terra, o equivalente a 669 mil hectares ou aproximadamente 28 mil lotes agrícolas, cobertos de matas, onde havia mais de quatro milhões de pinheiros e mais dois milhões de árvores nobres, como imbuias e cedros, chegando muitos deles a atingir 30 metros de altura e mais de um metro de diâmetro. Sua principal serraria era a Madeireira de Três Barras, a maior da América Latina na época, que tinha a capacidade de serrar $300 \mathrm{~m}^{3}$ de madeira por dia, o equivalente a 1.200 dúzias de tábuas e contava com mais de 800 empregados. Junto à Madeireira de Três Barras ela construiu um núcleo urbano de 250 casas para abrigar seus funcionários mais graduados. A Lumber tinha também uma serraria em Calmon, mais ao norte, próximo a Porto União, na divisa com o Paraná. Para facilitar o trabalho de derrubada das árvores, ela avançou trilhos mata adentro, os quais muitas vezes ultrapassavam os 30 quilômetros. Seus guindastes com longos cabos de aço alcançavam um diâmetro de até 200 metros. Suas modernas máquinas de serrar realizavam o trabalho de mais de cinco mil trabalhadores usando equipamentos convencionais.

Desde o fim da Guerra do Contestado e durante toda a década de 1920, a empresa foi hegemônica na extração e comercialização de madeira. Na década seguinte, foram criadas inúmeras serrarias de pequeno porte, que vieram a dar um novo impulso à atividade de extração de madeira, sem, contudo, ameaçar o domínio da Lumber. Em 1936, três estações de trem se destacavam em volume transportado: Caçador, Canoinhas e Três Barras. Em 1940, o montante exportado 
de madeira beneficiada na região do Contestado chegou a representar 19,10\% da totalidade das exportações catarinenses.

A Lumber de Três Barras construiu um mundo à parte no interior das matas da região. Uma cidade particular, com mais de 200 casas para os executivos e uma centena de outras para abrigar seus mais de 800 operários. Governada com suas próprias leis, funcionava como um verdadeiro território norte-americano dentro do país. As casas para os empregados superiores dispunham de água encanada, energia elétrica e aquecimento central. Havia também quadras de tênis para uso exclusivo dos diretores e de seus filhos. Até uma sala de projeção de filmes foi criada para a diversão dos operários. Todo esse complexo era muito bem protegido por pistoleiros armados, trazidos dos Estados Unidos.

O ciclo da madeira alcança seu auge entre 1930 e 1950 e termina uma década mais tarde, com o esgotamento dos pinhais de corte e de outras madeiras nobres. As atividades madeireiras contribuíram também para o povoamento e a urbanização da região, através das vilas rurais, onde residiam os trabalhadores das serrarias. Muitas dessas vilas se transformaram, depois, em municípios. No entanto, o ciclo da madeira pouco contribuiu para a formação inicial do capital na região, mas deixou como herança a devastação quase completa das matas, que antes cobriam esse imenso território. Só sobraram em torno de $2 \%$ delas.

Com o desenvolvimento da indústria madeireira, as próprias relações de trabalho foram se alterando, com a progressiva introdução do trabalho assalariado em substituição ao trabalho dos peões e dos diaristas. As condições de trabalho costumavam ser muito precárias, sem amparo legal e sem assistência médica e previdenciária, e os salários eram muito baixos. Por outro lado, sem uma política de controle, a exploração desenfreada da madeira provocou o rápido extermínio das florestas nativas e o fim do ciclo madeireiro. Além do extermínio das florestas, a atividade madeireira pouco contribuiu para a acumulação de capital na região, apesar de ter sido muito importante para os colonos que ali se instalavam, por fornecer a madeira para suas casas e demais instalações. Na verdade, o capital gerado pela indústria 
madeireira evadiu-se e deixou como herança, nessa região, um dos mais baixos índices de desenvolvimento humano. Em 1938, Getúlio Vargas estatizou a Lumber, que havia pedido concordata.

\section{REFERÊNCIAS}

BAVARESCO, Paulo Ricardo. Os Ciclos Econômicos do Extremo Oeste Catarinense: modernização, progresso e empobrecimento.(Dissertação de Mestrado). Blumenau, 2003.

POLI, Jaci. Caboclo: pioneirismo e marginalização. Cadernos do CEOM, Chapecó: Argos, 1995.

VALENTINI, Delmir José. A Guerra do Contestado (1912-1916). In: RADIN, José Carlos; VALENTINI, Delmir José; ZARTH, Paulo A.

História da Fronteira Sul. Porto Alegre: Letra\&Vida, 2015.

. Memórias da Lumber e da Guerra do Contestado. Porto Alegre:

Letra \& Vida; Chapecó: UFFS, 2015. 


\section{Modelo de desenvolvimento}

A característica básica do modelo de desenvolvimento regional do Oeste catarinense consiste na articulação orgânica das grandes indústrias de carnes, suínos, aves e leite, com a agricultura de escala familiar, que se formou ao longo do processo de colonização da região. Aqui, criaram-se as condições que permitiram a articulação da produção agrícola e da produção de suínos e aves com a indústria frigorífica, para formar as maiores empresas do setor de carnes e derivados do Brasil e, também, o maior complexo agroindustrial da América Latina. Utilizamos aqui o termo "desenvolvimento" no sentido de crescimento econômico, acompanhado da melhoria das condições de vida da população.

Desde o final do século XIX, o desenvolvimento do Oeste catarinense passou por um longo processo, em que se sucederam diversos "ciclos econômicos", como o da pecuária extensiva, o da indústria extrativa da erva-mate e da madeira, o ciclo da colonização e o da agroindústria frigorífica. Ao longo desses ciclos foi se formando a acumulação de capital, fator fundamental do desenvolvimento capitalista regional. Mas o capital começou a ser acumulado de forma significativa e contínua a partir da criação e do comércio de suínos pelos colonos, como desdobramento das atividades da agricultura familiar de subsistência.

O desenvolvimento socioeconômico da região Oeste catarinense possui características particulares se comparado ao desenvolvimento de outras regiões brasileiras. Sua base econômica e sua principal característica residem na agricultura familiar e na sua peculiar integração com as agroindústrias frigoríficas originadas e desenvolvidas na região, pois foi a partir da criação e comercialização de suínos, no seio da agricultura familiar, que se impulsionou a formação de capital comercial, fonte da acumulação e do desenvolvimento capitalista da região. Aos poucos, o capital comercial investido em matadouros e pequenos frigoríficos transformou-se progressivamente em capital industrial, motor da grande indústria frigorífica, típica da região. 
Esse modelo de desenvolvimento origina-se e estrutura-se progressivamente de acordo com a evolução do processo de integração entre a agricultura familiar e a indústria frigorífica. De início, a integração era baseada em acordos verbais informais, mas foi gradativamente se formalizando e aperfeiçoando através de contratos que estabeleciam uma relação de compra e venda garantida dos suínos, com preços e condições de pagamentos pré-fixadas, sem, contudo, interferir nas condições e formas de produção. Os primeiros contratos baseavam-se nos princípios da cooperação e proteção mútuas e atendiam aos objetivos tanto dos agricultores como dos frigoríficos. Até a década de 1950, a capacidade produtiva dos frigoríficos dependia da produção familiar de suínos. A influência das indústrias sobre a produção só ocorria de forma indireta. Nesse período, os agricultores gozavam de uma grande autonomia na gestão de suas atividades. Mas a criação do Departamento de Fomento Agropecuário pela Sadia, na década de 1960, estabelece um novo marco nesse processo de integração, pois começava a interferir no processo produtivo de suínos e na oferta da matéria-prima fornecida pelos agricultores. $\mathrm{O}$ aperfeiçoamento e a generalização deste modelo inicial de integração operado pela Sadia significaram um grande impulso, tanto para as atividades frigoríficas, como para a criação de suínos. A partir daí,a indústria frigorífica continuou a aprofundar sua ingerência sobre a criação de suínos feita pelos agricultores, visando sempre melhorar a produção e a produtividade. A iniciativa da integração foi da indústria frigorífica, motivada pela necessidade de garantir uma contínua oferta de produtos homogêneos e de boa qualidade por parte dos agricultores. Estes, por sua vez, tinham assegurada a venda de sua produção. Por seu lado, a integração também operou mudanças na natureza da produção agrícola familiar, que destinada inicialmente à subsistência, com o aprofundamento da integração, passa a ser uma produção para o mercado.

Depois foram se estreitando os laços entre produtores e frigoríficos, através dos contratos de integração, que envolviam não apenas preços e condições de pagamento, mas interferiam, também, na maneira de produzir das unidades rurais, com fornecimento de assistência 
técnica, rações e transporte da produção. Nesse contrato, os produtores se comprometem a cumprir rigorosamente um conjunto de normas técnicas estabelecidas pelas empresas, que incluem desde as instalações e os cuidados com os animais, bem como a entrega dos animais terminados em prazos preestabelecidos pelos frigoríficos. Além disso, os agricultores devem oferecer a mão de obra necessária para a produção e arcar com os encargos sociais. O não cumprimento dessas exigências contribui para a gradativa exclusão dos agricultores do contrato de integração.

Para os agricultores, a integração garante o escoamento de toda a produção, além de assistência técnica e maior facilidade ao crédito. Para as agroindústrias, matéria-prima de qualidade a um custo menor, já que elas não necessitam investir em instalações, terras e mão de obra. A integração implica, também, produção de melhor qualidade, melhorias nas instalações físicas e novas técnicas produtivas, que potencializam a pequena propriedade rural.

Um novo padrão de integração tornou-se dominante, na década de 1980, que passou a ser chamado de modelo de integração de ciclo completo, no qual os agricultores tinham o controle e o comando do processo de produção, que se baseava muito mais no conhecimento, na capacidade produtiva e na organização da produção feita pelos próprios agricultores, mas incluía também a introdução de novas técnicas produtivas, novas raças de suínos e novas estruturas de produção. Nos anos 1990, o modelo de ciclo completo foi sendo substituído pelo modelo de parceria, que se torna dominante a partir dos anos 2000. Nesse sistema de parceria, as responsabilidades de cada uma das partes ficam claramente estabelecidas: os agricultores entram com as instalações, os equipamentos e a mão de obra; as agroindústrias frigoríficas fornecem os animais, os insumos, os medicamentos e a assistência técnica. A remuneração que os agricultores recebem depende de sua produtividade, mas os critérios de cálculo da produtividade são impostos pelas agroindústrias e não são conhecidos pelos próprios agricultores. Na década de 1970, a criação de aves passa a ser feita de acordo com o mesmo modelo de integração aplicado à criação de suínos. Mesmo exigindo investimentos iniciais altos, a avicultura oferece resultados 
maiores e mais rápidos que a suinocultura. Talvez, por isso, apesar de ter iniciado algumas décadas depois da suinocultura, a avicultura expandiu rapidamente e consolidou-se como principal atividade agroindustrial da região. Esse complexo agroindustrial regional de suínos e aves, iniciado nos anos 1940 e 1950, torna-se maduro e consolida-se nas décadas de 1970 e de 1980, transformando-se na base do desenvolvimento econômico regional.

O sistema de integração, embora tenha alterado o modo de vida colonial, inserindo novas formas de relações de produção e um novo ambiente social e econômico, significou um avanço na produção familiar e uma melhoria nas condições de vida dos agricultores integrados. Apesar de subordinados ao capital industrial, os agricultores ainda continuam proprietários de suas terras e de seus meios de produção. Mas, por outro lado, a integração implicou, também, em grandes perdas, sobretudo em relação a sua autonomia e ao controle sobre sua produção. Os pequenos produtores rurais conservaram, contudo, muitos elementos de seu antigo modo de vida de colonos e de agricultores familiares. Em geral, os que conseguiram manter-se melhoraram sua condição de vida e se adaptaram ao novo sistema de produção e ao modo de vida dele decorrente.

O resultado da dinâmica desse modelo foi que, em poucas décadas, operou-se um rápido e vertiginoso processo de transformação de uma região colonial de pequenos produtores, que produziam basicamente para a subsistência, em uma economia agroindustrial poderosa, líder na produção para mercados nacionais e forte competidora nos mercados internacionais.

No entanto, as virtudes desse modelo vêm acompanhadas de contradições, pois o mesmo modelo responsável pelo desenvolvimento é também um modelo de grande concentração econômica, de capital e de riqueza, e de exclusão dos pequenos produtores, responsável também pelo êxodo rural dos trabalhadores mais jovens, pela degradação do solo decorrente da poluição do meio ambiente, sobretudo dos seus mananciais de água. 


\section{REFERÊNCIAS}

BAVARESCO, Paulo Ricardo. Os Ciclos Econômicos do Extremo Oeste

Catarinense: modernização, progresso e empobrecimento.(Dissertação de Mestrado). Blumenau, 2003.

MELLO, Márcio Antônio de; SCHNEIDER, Sérgio. A Produção de "novidades" como alternativa à crise pelos agricultores do Oeste de Santa Catarina. Desafio Online, Campo Grande, v. 1, n. 3, set./dez. 2013. MIOR, Luiz Carlos. Agricultores familiares, agroindústrias e redes de desenvolvimento rural. Chapecó: Argos, 2005.

OLIVEIRA, Antônio Marcos P. A dinâmica do desenvolvimento regional. (Dissertação de Mestrado). Universidade Municipal de São Caetano do Sul, 2010.

PIVA, Ana Sílvia. Formação do Sistema Agroindustrial e os Fluxos Migratórios na Mesorregião Oeste Catarinense. (Monografia). Florianópolis: UFSC, 2010. 


\section{Movimento das Mulheres Camponesas (MMC)}

O Movimento das Mulheres Camponesas (MMC) é um movimento social organizado em nível nacional, na década de 1980, a partir da unificação de diversos movimentos de mulheres agricultoras espalhados pelas diferentes regiões do país. Ele se define como um movimento "autônomo, democrático, popular, classista" e luta por uma perspectiva socialista de sociedade (mmcbrasil.com.br).

Na região Oeste de Santa Catarina, a constituição de um movimento específico de mulheres agricultoras contou com o apoio decisivo de segmentos da Igreja Católica, de modo especial as comunidades eclesiais de base e a Comissão Pastoral da Terra, cujas ações sempre contaram com o estímulo e o apoio do bispo de Chapecó, Dom José Gomes. A origem e evolução do MMC, na região Oeste, estão associadas a diversos eventos (POLI, 1999). O marco histórico inicial teria sido o dia 25 de julho de 1981, por ocasião das comemorações do dia do colono, no então distrito de Itaberaba, município de Chapecó. Foi neste lugar e nesta ocasião que se formou, inicialmente, o Movimento das Mulheres Agricultoras (MMA). A partir deste marco inicial, foram desenvolvidas as primeiras ações concretas para estruturar um movimento social de mulheres agricultoras. Em $1^{\circ}$ de maio de 1983, Dia do Trabalho, realizou-se outro encontro importante, que reuniu 28 mulheres de diversas comunidades da região, entre as quais se incluíam líderes camponesas, líderes sindicais e agentes pastorais. Em 08 de março de 1984, dia Internacional da Mulher, as camponesas fundaram a Organização das Mulheres Agricultoras (OMA) e, em 1986, decidiu-se pela consolidação do Movimento de Mulheres Agricultoras (MMA) de Santa Catarina. Em 2003, foi tomada a decisão conjunta de unificar as diferentes organizações de mulheres de quatorze estados brasileiros, unificação que veio a materializar-se, em 2004, com a criação do Movimento das Mulheres Camponesas (MMC). 
A motivação inicial, que desencadeou a formação dos diversos movimentos de mulheres camponesas, foi condição subordinada da mulher no seio da família, no sindicato de pequenos agricultores e na sociedade. Foi a partir das conversas e debates no âmbito das diversas organizações de mulheres, que foi se formando a consciência e o questionamento das condições desiguais e discriminatórias enfrentadas pelas mulheres e a necessidade de lutar contra elas. No próprio sindicato de trabalhadores rurais, elas não tinham direito a voto, nem a concorrer a cargos de lideranças. Só podiam participar do sindicato, mulheres solteiras e autônomas. Mulheres casadas nem poderiam ser sócias do sindicato. A partir dessas lutas concretas pela igualdade de direitos no seio da família e na vida sindical, a luta das mulheres camponesas transformou-se numa luta pelas transformações sociais.

O MMC trabalha com um conceito amplo de mulher camponesa: "somos mulheres agricultoras, arrendatárias, meeiras, ribeirinhas, posseiras, boias-frias, diaristas, parceiras, extrativistas, quebradeiras de coco, pescadoras artesanais, sem-terra, assentadas, mulheres índias, negras, descendentes de europeus. Somos a soma da diversidade das mulheres do nosso país". (mmcbrasil.com.br).

A pauta de lutas do MMC também é ampla e diversa como o próprio conceito de mulher camponesa. Entre elas, destaca-se o reconhecimento da profissão de trabalhadora rural, o salário-maternidade, a aposentadoria da mulher da roça aos 55 anos, a luta por saúde de qualidade, por políticas públicas, que atendam aos interesses das camponesas, pelas condições de permanência no meio rural, pela construção de novas relações sociais e de gênero, e pelo fim de todas as formas de violência e opressão.

Ao mesmo tempo, o MMC tem consciência de que a luta das mulheres camponesas é uma luta delas mesmas: "lutar sempre foi nossa condição", "a luta pela libertação das mulheres é tarefa de todos", mas "a libertação da mulher é obra da própria mulher, fruto da organização e da luta", "nós mulheres somos as principais responsáveis por esta conquista". Por isso, o MMC define-se como "movimento autônomo, democrático, popular, feminista" e ao mesmo tempo é movido pela convicção de que a condição da mulher camponesa só muda se 
mudar também a sociedade em que ela vive, a luta do MMC é uma luta de "classe social, na perspectiva socialista". Trata-se de uma "luta por novas relações entre as pessoas e destas com a natureza". "Pertencemos à classe trabalhadora, lutamos pela causa feminista e pela transformação da sociedade". A luta das mulheres camponesas é a luta de todos os trabalhadores e trabalhadoras. O MMC luta para que as mulheres camponesas sejam sujeitos da sua própria história (www. mmcbrasil.com.br).

\section{REFERÊNCIAS}

POLI, Odilon Luiz. Leituras em Movimentos Sociais. Chapecó: Grifos, 1999.

LACERDA ADÃO, Nilton Manoel. Movimento das mulheres camponesas: a origem religiosa e o "cuidado" na estrutura familiar. In: PERETTI, Clélia (Org.) Congresso de Teologia da PUCPR. Champagnat, 2011. Disponível em: <http://www.pucpr.br/eventos/congressoteologia/2011>. Acesso em: 27 abr. 2016. 


\section{Movimento dos Atingidos por Barragens (MAB)}

O Movimento dos Atingidos por Barragens (MAB) é um movimento social popular, de âmbito nacional, criado na década de 1970, a partir da mobilização de agricultores da região do Alto Uruguai, nos estados do Rio Grande do Sul e Santa Catarina, contra a construção de usinas hidroelétricas que invadiam suas terras e destruíam suas condições de sobrevivência. Seu objetivo original era organizar os atingidos pela construção de barragens para a defesa de seus direitos. A mobilização surgida no Alto Uruguai espalhou-se para outras regiões do país e o movimento assumiu um caráter nacional, nos anos 1980. Na década de 1990, os atingidos por barragens do mundo inteiro uniram suas lutas para formarem uma organização internacional. Sua pauta de reivindicações ampliou-se e mudou de natureza. Aquilo que, no início, era uma demanda por indenização dos atingidos, transformou-se na defesa do direito de permanecer na terra e assumiu a forma de uma política internacional sobre o uso da água e da energia, os quais, por serem considerados essenciais à vida, devem ser bens públicos a serviço de todos e não mercadorias negociáveis no mercado.

Atualmente, o Movimento dos Atingidos por Barragens tem representação em 16 estados do Brasil e congrega um conjunto diversificado de pessoas, que inclui pequenos agricultores, trabalhadores rurais, meeiros, parceiros, arrendatários, posseiros, povos indígenas, populações quilombolas, pescadores e mineradores, dentre outros. $\mathrm{O}$ dia 14 de março foi escolhido como Dia Internacional de Luta Contra Barragens.

A preocupação inicial do MAB surgiu, ainda em 1979, antes mesmo da construção efetiva das barragens, quando se divulgaram os primeiros estudos sobre o aproveitamento do potencial hidroelétrico da região do Alto Uruguai. As pessoas potencialmente ameaçadas de perder suas propriedades compareceram a uma reunião 
promovida pela Comissão Pastoral da Terra, onde foi proposta a criação de uma Comissão de Barragens, a qual mais tarde foi chamada de Comissão Regional de Atingidos por Barragens (CRAB). A mobilização ampliou-se nos anos seguintes para outras regiões do país, onde se formaram comissões regionais. A partir de 1985, as comissões regionais unificaram suas lutas, criando o Movimento dos Atingidos por Barragens. Em 1986, realizou-se a primeira assembleia geral do movimento. Em abril de 1989, foi realizado o I Encontro Nacional de Trabalhadores Atingidos por Barragens, em Goiânia e, em março de 1991, realizou-se o I Congresso Nacional de Atingidos por Barragens. Em março de 1997, foi realizado o Primeiro Encontro Internacional dos Povos Atingidos por Barragens, na cidade de Curitiba, onde estiveram representados mais de 20 países de diversos continentes. $\mathrm{O}$ compartilhamento de experiências nacionais na defesa dos direitos das famílias atingidas criou as condições para o fortalecimento internacional do Movimento e a formulação mundial de políticas energéticas. No mesmo ano de 1997, foi criada na Suíça a Comissão Mundial de Barragens (CMB), ligada ao Banco Mundial, com o objetivo de propor soluções para os problemas causados pelas construtoras de barragens.

No IV Congresso Nacional do MAB, realizado em novembro de 1999, em Minas Gerais, foi defendido um novo modelo energético para o Brasil. Em junho de 2003, aconteceu o Primeiro Encontro Nacional do Movimento dos Atingidos por Barragens, em Brasília, no qual se reafirmou a luta popular como o único instrumento capaz de obter conquistas concretas para os povos atingidos. No ano seguinte, o MAB realizou a Marcha Nacional Águas pela Vida, uma marcha histórica, de Goiânia a Brasília, com o objetivo de exigir do governo federal o cumprimento dos direitos dos atingidos. Mais de 600 pessoas participaram da marcha. Em março de 2006, realizou-se o Segundo Encontro Nacional dos Atingidos por Barragens, em Curitiba, com a participação de cerca de 1.200 atingidos de todo Brasil, que reafirmaram o caráter nacional, popular, sindical e político do $\mathrm{MAB}$, bem como a importância das especificidades regionais do Movimento. 


\section{REFERÊNCIAS}

DALLA COSTA, Luis. Atingidos por barragens: retrocesso extraordinário na política de direitos. Entrevista especial ao IHU On-Line, São Leopoldo: Unisinos: 12/03/2013.

FOSCHIERA, A. A.; BATISTA, L. S.; THOMAZ JR, A. Organização e atuação do movimento dos atingidos por barragens: o caso do MAB/TO.

Revista Pegada, vol. 10 n.1, junho/2009. Disponível em: <http://revista.fct. unesp.br/index.php/pegada/article/view/1684>.Acesso em: 27 abr. 2016. 


\section{Movimento dos Pequenos Agricultores (MPA)}

O Movimento dos Pequenos Agricultores (MPA) é um movimento social camponês, de caráter popular, de massa, autônomo e de luta permanente, constituído por grupos de pequenos agricultores organizados nacionalmente. Seu principal objetivo é a produção de comida saudável para as próprias famílias e também para todo o povo brasileiro, garantindo, assim, a soberania alimentar do país. Além disso, busca o resgate da identidade e da cultura camponesa, respeitando as diversidades regionais.

O MPA surgiu da crise do movimento sindical e da crise do modelo de agricultura apoiado na revolução verde, que gerou empobrecimento e exclusão no campo. Ele também se inspirou nas lutas de outros movimentos populares, como o das comunidades eclesiais de base, a Comissão Pastoral da Terra e o próprio Movimento dos Trabalhadores Rurais Sem-Terra, que apontaram caminhos para a construção deste novo movimento.

O fim do departamento rural da Central Única dos Trabalhadores (CUT) deixou órfãos e abandonados muitos sindicatos combativos, os quais se viram forçados a buscar outras formas de organização. Algumas lideranças, membros do Departamento Rural da CUT, iniciaram tratativas a respeito da necessidade de criar outro movimento com esse caráter. O primeiro chamamento aconteceu por ocasião da seca, que atingiu o Sul do Brasil no final de 1995 e início de 1996. O Acampamento da Seca, que se imaginava reunir entre 3 mil e cinco mil pessoas, com o objetivo de reivindicar mais crédito para a manutenção familiar, em poucos dias de acampamento já reunia mais de 30.000 . No final de 1997, houve um primeiro encontro nacional visando iniciar um movimento dos pequenos agricultores e, em julho de 1998, um segundo encontro conseguiu definir as principais características do MPA: um movimento de massas, de luta permanente, com organização de base e com bandeiras simples, claras e objetivas. O MPA 
integra a Via Campesina, uma articulação internacional de movimentos camponeses que, junto com outros movimentos e setores da sociedade, luta por um projeto popular de desenvolvimento para o Brasil.

No Oeste catarinense, o MPA está representado pela Associação dos Pequenos Agricultores do Oeste Catarinense (APACO), uma Organização Não Governamental, sem fins lucrativos. Ela foi fundada em 20 de novembro de 1989, com o objetivo de estimular e assessorar o desenvolvimento da agricultura de grupo e mesmo implementar na região um novo modelo de desenvolvimento, baseado na solidariedade e sustentabilidade. Sua criação contou com o apoio decisivo do movimento sindical, popular e de setores da Igreja. Fundamenta-se na agroecologia e na agroindústria familiar associativa de pequeno porte, na busca de melhores condições de vida para os pequenos agricultores familiares da região. É formada e dirigida por grupos de agricultores familiares que se organizam e desenvolvem atividades de forma cooperada. Sua sede está localizada na cidade de Chapecó.

Atualmente o MPA está organizado em 17 estados da Federação. Seu plano camponês de lutas assenta-se em dois pilares: as condições para produzir e as condições para viver bem no campo e se confronta diretamente com o Plano do Agronegócio. Em sua breve história, o MPA já obteve muitas conquistas, tais como a afirmação do conceito de campesinato e da identidade camponesa, a elaboração do Plano Camponês, a conquista do crédito subsidiado para os pequenos agricultores e o crédito para as habitações no campo, entre outras.

\section{REFERENCIAS}

ASSOCIAÇÃO DOS PEQUENOS AGRICULTORES DO OESTE CATARINENSE. Disponível em: <www.apaco.org.br>. Acesso em: 27 abr. 2016.

MOVIMENTO DOS PEQUENOS AGRICULTORES. Disponível em: <www.mpabrasil.org.br>. Acesso em: 27 abr. 2016. 


\section{Movimento dos Trabalhadores Rurais Sem Terra (MST)}

O Movimento dos Trabalhadores Rurais Sem Terra (MST) tem suas raízes nos movimentos sociais, que marcaram a luta pela terra no país ao longo de sua história, mas suas origens efetivas estão associadas às lutas dos diversos movimentos de agricultores, organizados em várias regiões brasileiras, no período final dos anos 1970 e início dos anos 1980. Esses diversos movimentos regionais forneceram a motivação e a base para criação de um movimento nacional em defesa dos trabalhadores rurais sem-terra, o que veio a materializar-se em janeiro de 1984, durante um encontro de lideranças de trabalhadores rurais de vários Estados, reunidos em Cascavel, no Estado do Paraná. No ano seguinte, em 1985, o MST já realizava seu Primeiro Congresso Nacional. Neste mesmo ano, o governo brasileiro anunciava o Plano Nacional de Reforma Agrária (PNRA), cuja primeira versão contou com participação dos trabalhadores sem-terra, mas que, posteriormente, sofreu retrocessos em favor dos ruralistas (PAIM; SIQUEIRA, 2014). No Congresso de 1985, foram criados o hino, a bandeira e o lema do Movimento: “Ocupar é a única solução”, em substituição ao lema anterior "Terra para quem trabalha".

No plano político, a criação do MST se contrapõe ao projeto de desenvolvimento agrícola do regime militar dos anos 1960 e 1970, o qual estava centrado na política de colonização e transferência das populações para a nova fronteira agrícola, localizada sobretudo no Centro-Oeste e na Amazônia. O fracasso desta política oficial desencadeou vários movimentos de ocupação de terras, em diversos estados brasileiros, gerando muitos focos de conflito no campo. Ocupar terras improdutivas transformou-se na bandeira e na estratégia nacional de ação do Movimento.

No Oeste de Santa Catarina, a origem do MST está associada a diversos fatores regionais, como a luta histórica dos povos ali estabelecidos, índios, caboclos e colonos, pela posse ou pela propriedade da terra, 
o êxodo rural decorrente da mecanização da agricultura, nos anos 1960 e 1970, e as transformações econômicas e sociais decorrentes da modernização da agricultura, nos anos 1980 e 1990. A luta pela terra é parte constitutiva da formação socioeconômica regional. A história desta região está marcada pelas disputas entre os diferentes grupos sociais, que tinham na terra sua própria reprodução social, com seus modos de vida, seus valores e suas práticas culturais. A modernização da agricultura das décadas de 1980/90 excluiu grande número de pequenos agricultores integrados à produção agroindustrial, que não conseguiram modernizar-se e passaram a ter grandes dificuldades para sobreviver. Foram marcos na história do MST do Sul do Brasil o Acampamento da Encruzilhada Natalino, em Ronda Alta, no Rio Grande do Sul, em 1978, e a ocupação da Fazenda Macali, no município de Sarandi, em 1979.

Efetivamente, a história do MST no Oeste de Santa Catarina tem início em maio de 1980, com a ocupação da Fazenda Burro Branco, no município de Campo Erê, por mais de 300 famílias. A área foi desapropriada, em 12 de novembro do mesmo ano, medida que estimulou novas ocupações de terras, no Oeste catarinense. Em dezembro de 1984, realizou-se, em Chapecó, o I Congresso dos Trabalhadores Sem Terra no Estado de Santa Catarina. Em maio de 1985, mais de 1.600 famílias ocupam sete áreas em municípios da região. Nos anos subsequentes, os sem-terra continuam a ocupar outras áreas. Atualmente, estão implantados mais de cem assentamentos rurais e algumas dezenas de acampamentos distribuídos em todo o território catarinense. O MST, como aconteceu também com outros movimentos sociais, contou desde suas origens com o incentivo e o apoio de partidos políticos de esquerda e de segmentos da Igreja Católica, representados nas comunidades eclesiais de base e, especialmente, na Comissão Pastoral da Terra.

$\mathrm{Na}$ organização dos assentamentos, o MST procura substituir a prática tradicional do trabalho individual camponês, fundado na agricultura familiar, por formas coletivas de trabalho, criando cooperativas de produção ou de distribuição, com o objetivo de viabilizá-los economicamente, garantir uma vida digna, manter a coesão do grupo e realimentar sua capacidade de organização política. Com este objetivo de desenvolver o espírito e a organização cooperativista nos assentamentos, 
o MST criou o Sistema Cooperativista dos Assentados (SCA). Procura também criar centrais de cooperativas estaduais, bem como uma organização nacional articulada na forma de uma confederação (CONCRAB). Essas entidades visam tanto organizar a produção, a melhoria da qualidade de vida e a permanência dos assentados no campo, como também alimentar a consciência política dos assentados visando a transformação social. Para alcançar esse objetivo, o MST procura colocar em prática um ambicioso projeto de educação de base, que inclui a formação política, técnica e escolar, a ser implementada através de cursos próprios, em parcerias com universidades, institutos e prefeituras, nas escolas vinculadas às redes estaduais e municipais que funcionam em alguns acampamentos e nos assentamentos rurais. Nessas escolas do MST, que em todo o país somam em torno de duas mil, em acampamentos ou itinerantes, estudam mais de 200 mil crianças, jovens e adultos. Nelas, também, cerca de 50 mil adultos foram alfabetizados. Outros dois mil alunos estão matriculados em cursos técnicos. Além da luta pela Reforma Agrária, o MST defende uma agenda ampla de transformações econômicas, políticas e sociais.

\section{REFERÊNCIAS}

MST. Movimento dos Trabalhadores Rurais Sem Terra. Disponível em: <http://www.mst.org.br>. Acesso em: 10 abr. 2016.

PAIM, Elison Antonio; SIQUEIRA, Gustavo Henrique. CPT e MST:

formação e ocupação no oeste catarinense. Revista Santa Catarina em

História, v. 8, n. 1, Florianópolis, 2014.

POLI, Odilon Luiz. Leituras em Movimentos Sociais. Chapecó: Grifos, 1999.

ROCHA, Douglas Satirio. O MST no Oeste de Santa Catarina e sua atuação através da imprensa escrita local (1985-1989). Revista Santa Catarina em

História, v.7, n.2, Florianópolis, UFSC, 2013. 


\section{Movimentos sociais}

Movimentos sociais são ações coletivas de setores da sociedade ou de organizações sociais, de natureza mais ampla e diversificada que a noção tradicional de classe social, que buscam defender direitos e promover maior participação social e política na organização e nos rumos da sociedade em que estão inseridos. Nesse sentido amplo, os movimentos sociais foram recorrentes ao longo da história da humanidade. Para o Dicionário de Ciências Sociais da Fundação Getúlio Vargas (1986), movimentos sociais são "tentativas coletivas de provocar mudanças, no todo ou em parte, em determinadas instituições sociais, ou de criar uma nova ordem social". Novos movimentos sociais surgiram principalmente na América Latina, a partir da década de 1970, muitas vezes se identificando com movimentos populares, ou mesmo deles se diferenciando, especialmente por serem mais duradouros do que estes últimos, mas com uma agenda ampla de lutas sociais, de caráter reivindicatório e político, no sentido de visar influir nas decisões e rumos políticos do país, ou mesmo contestatório e revolucionário em relação ao sistema econômico e social vigente. Esses novos movimentos sociais defendem livre organização, autogestão, democracia de base, direito à diversidade e respeito à individualidade e à diferença, questões ecológicas, de gênero, etnia, sexo etc. A partir dessas questões específicas, esses movimentos passaram a discutir questões mais amplas, relacionadas com a estrutura social e a própria constituição da sociedade.

No Brasil a história dos movimentos sociais também é bastante antiga. Desde os tempos coloniais, mas sobretudo ao longo do Século XIX, foram frequentes os movimentos sociais e populares, tais como a Cabanagem, a Balaiada, a Sabinada e a Revolta dos Malês, entre outros. O Regime Militar de 1964 coloca-se como um divisor entre os velhos movimentos sociais, a exemplo das ligas camponesas, nos anos 1960, e os novos movimentos sociais, marcadamente nas décadas de 1970 e 1980, que buscam resistir à repressão, fortalecer a sociedade civil e lutar pela redemocratização do país (FOSCHIERA;BATISTA e JUNIOR, 2009). Em sua variedade, os movimentos sociais mais recentes 
caracterizam-se pela mobilização coletiva por direitos, por justiça e por melhores condições de vida. Buscam ser autônomos em relação ao Estado e se afirmam como importante fator de transformação social.

No Oeste catarinense, assim como em outras regiões do Brasil, a origem dos movimentos sociais recentes está diretamente relacionada à questão da terra (ROCHA, 2013), pois a luta pela terra é parte constitutiva dessa formação socioeconômica regional. A história desta região está marcada pelas disputas entre os diferentes grupos que nela se estabeleceram e buscaram garantir, através da posse ou da propriedade da terra, sua própria reprodução social, com seus modos de vida, seus valores e suas práticas culturais. A importância da luta pela terra foi de tal ordem que os principais movimentos sociais da região, mesmo no período mais recente, estão associados ao mundo rural.

Ao lado da luta pela terra, os movimentos sociais no campo também estão associados às transformações econômicas e sociais decorrentes da modernização da agricultura, nos anos 1980 e 1990, as quais excluíram grande número de pequenos agricultores integrados à produção agroindustrial que não conseguiram modernizar-se e passaram a ter grandes dificuldades para sobreviver. Esses Movimentos Sociais mais recentes representam também uma reação frente à ruptura do modelo de produção agrícola e da modernização da agricultura que desestruturou a produção agrícola familiar tradicional na região.

Foi assim que se originaram diversos movimentos sociais rurais na região Oeste catarinense, no final dos anos 1970 e no decorrer dos anos 1980. Esses movimentos contaram com o incentivo e o apoio dos partidos políticos de esquerda e de segmentos da Igreja Católica, como a Comissão Pastoral da Terra (CPT) e o Conselho Indigenista Missionário (CIMI). O seu embrião está localizado nos diversos cursos de formação de lideranças e promoção de associações por esses organismos. Foi decisiva também a atuação do bispo de Chapecó, Dom José Gomes. Os principais atores envolvidos nessa luta foram os agricultores sem-terra, parceiros, posseiros ou filhos de pequenos proprietários agrícolas, os trabalhadores assalariados do campo, as mulheres agricultoras, os atingidos por barragens e outras forças coletivas emergentes aglutinadas pela bandeira da reforma agrária. 
Os principais movimentos sociais surgidos e organizados na região Oeste de Santa Catarina, nos anos 1980, foram o Movimento dos Trabalhadores Rurais sem Terra (MST), criado em 1984, o Movimento das Mulheres Camponesas (MMC), que resultou da unificação de várias associações de mulheres agricultoras durante a década de 1980, o Movimento dos Atingidos por Barragens (MAB), originado a partir da construção de barragens no rio Uruguai entre o Rio Grande do Sul e Santa Catarina, no final dos anos 1970, e o Movimento dos Pequenos Agricultores (MPA), no decorrer dos anos 1990. A partir de uma base regional, todos esses movimentos sociais tenderam associar-se com movimentos similares de outras regiões, transformando-se em movimentos de abrangência nacional.

De modo geral, todos esses movimentos expressam as contradições de seu tempo e as lutas por uma verdadeira democracia participativa que promova a construção de uma nova sociedade, marcada por formas socializadas de organização econômica e social.

\section{REFERÊNCIAS}

DALLA COSTA, Luis. Atingidos por barragens: Retrocesso extraordinário na política de direitos. Entrevista especial ao IHU On-Line, São Leopoldo: Unisinos: 12/03/2013.

FOSCHIERA, A. A.; BATISTA, L. S.; THOMAZ JR, A. Organização e atuação do movimento dos atingidos por barragens: o caso do MAB/TO.

Revista Pegada, vol. 10, n.1, junho/2009. Disponível em: $<$ http://revista.fct. unesp.br/index.php/pegada/article/view/1684>. Acesso em: 27 abr. 2016. FUNDAÇÃO GETÚLIO VARGAS. Dicionário de Ciências Sociais. Rio de Janeiro: FGV, 1986.

POLI, Odilon Luiz. Leituras em Movimentos Sociais. Chapecó: Grifos, 1999. ROCHA, Douglas Satirio. O MST no Oeste de Santa Catarina e sua atuação através da imprensa escrita local (1985-1989). Revista Santa Catarina em História, v.7, n.2, Florianópolis: UFSC, 2013. 
Os monges foram personagens que peregrinaram por diversas cidades do Sul do Brasil, sobretudo pelas terras do Oeste catarinense, na segunda metade do século XIX e início do século XX, pregando, fazendo profecias e "curas milagrosas". Eles reuniam grande número de fiéis seguidores. Há controvérsias sobre o número, o nome e o papel desempenhado por eles.

Para Machado (2001), houve, pelo menos, três monges diferentes, que percorreram a região da Fronteira Sul naquele período. O primeiro foi João Maria de Agostinho, um monge peregrino de origem italiana, que esteve em Sorocaba, em dezembro de 1844, percorreu o sul do Brasil, incluindo Candelária e Campestre no Rio Grande do Sul, durante anos, e teria desaparecido misteriosamente. Welter (2007) refere-se a este monge como sendo José Maria d'Agostinho.

Em estudo recente, Karsburg (2012) reconstituiu a longa e incrível trajetória do monge eremita. Evidencia sua passagem em vários estados do Brasil, como Rio Grande do Sul, Santa Catarina, São Paulo e Rio de Janeiro. Também mostra que ele foi o "peregrino das Américas”, passando pela Argentina, Chile, Paraguai, Bolívia, Peru, México, Cuba, Canadá e Estados Unidos. No Botucaraí, próximo a Santa Maria da Boca do Monte, em 1948, foi detido e levado a Porto Alegre para prestar esclarecimentos sobre sua participação no evento das "Águas Santas". A ele se atribuiu a descoberta da fonte de água milagrosa. No ano seguinte teria autoexilado-se na ilha de Arvoredo, ao norte de Desterro. Não apenas o povo, mas autoridades e padres o reconheciam pelo seu conhecimento das escrituras e das línguas latina e francesa. Teria sido recebido por D. Pedro II e inocentado pelo ministro da Justiça, Euzébio de Queiroz, "das suspeitas de charlatanismo, exercício ilegal da medicina, falsas promessas de cura e impostura religiosa”. No Rio de Janeiro viveu na Pedra da Gávea, onde recebia visitas de escravos que iam levar-lhe mantimentos a mando dos seus senhores e de lá retornavam com rosários e crucifixos fabricados pelo eremita. "Após realizar nova travessia pelos sertões meridionais brasileiros, apresentou-se 
à Secretaria de Polícia de Porto Alegre, em 10 de fevereiro de 1852, requerendo passaporte para o Paraguai”. Foi para a província de Misiones, onde se estabeleceu no Cerro del Monje, seguindo sua peregrinação pela América. Em 1853, esteve novamente em Buenos Aires e entre 1855 a 1858 permaneceu no Chile. Passou após pela Bolívia (1858), pelo Peru (1859), pelo México e por Cuba (1861), até atingir o Canadá, em 1862, ano que também marcou sua entrada nos Estados Unidos, onde fez longa caminhada de quase mil quilômetros, até estabelecer-se no Novo México. Alertado pelos moradores que seria perigoso viver sozinho em função da presença de índios, teria dito: "toda a sexta-feira acenderei uma fogueira para avisar que continuo vivo e orando por vocês". Em abril de 1869, como a fogueira no alto do cerro não mais se acendeu, os moradores subiram até a caverna e "encontraram-no estendido, de bruços e segurando firmemente seu rosário. Havia sido assassinado, crime jamais solucionado".

Sobre o segundo monge, há consenso que seria João Maria de Jesus, de origem síria, cujo nome original era Anastas Marcaf. Com características e trajetória semelhantes ao primeiro, também percorreu a região e exerceu grande influência no imaginário da população cabocla, que passou a atribuir-lhe poderes e práticas milagrosas e a ser chamado de São João Maria e também teria desaparecido misteriosamente, entre 1908 e 1910 (MACHADO, 2001). Muitos seguidores acreditam, entretanto, que teria passado a viver de forma "encantada" até hoje no morro do Taió, pequena localidade próxima de Rio do Sul. Um terceiro monge, José Maria, apareceu na região contestada, em 1912, "uma figura de passado nebuloso", cuja personalidade e papel dividiu os próprios caboclos (MACHADO, 2001), envolvidos em diversos episódios que precipitaram a guerra sertaneja. Para alguns, o monge José Maria era um falso profeta que explorava a boa fé do povo, cuja vinda já fora prevista pelo monge anterior, São João Maria, de quem ele se dizia irmão; para outros, porém, se tratava de um homem penitente dedicado a ações de cura e de caridade. Para seus adversários, principalmente padres e autoridades, tratava-se de um charlatão curandeiro. Os que conviviam com ele negam tais acusações, pois suas práticas de curandeirismo com ervas medicinais eram 
muito comuns e aceitas como práticas normais na região. Como seus antecessores, José Maria perambulou por muitos municípios do território contestado, pregando, fazendo profecias e praticando curas milagrosas, até que, por razões fortuitas, juntou-se aos caboclos, acampados, primeiro em Taquaruçu e depois no Irani, quando foi atacado e morto pelas forças militares do Estado do Paraná, em 22 de outubro de 1912, no episódio que marcou o início da Guerra do Contestado.

Segundo consta no Formulário de Apresentação de estrangeiros, lavrado em Sorocaba, em 24 de dezembro de 1844, João Maria d'Agostinho teria desembarcado no Pará, de onde viajou para o Rio de Janeiro, chegando depois a São Paulo. Declarou ter 43 anos, ser solteiro, como profissão ser solitário eremita e veio ao Brasil exercer seu ministério religioso. Declarou, também, morar nas matas do Termo da Cidade, em Sorocaba, de onde iniciou sua peregrinação pelos estados do Sul, principalmente nas terras do Contestado do Paraná e Santa Catarina, mas percorreu também cidades do Rio Grande do Sul e fez incursões pelo Paraguai. Fachel (1995) refere-se a este monge como sendo João Maria de Agostini e analisa sua presença em diversas cidades do Rio Grande do Sul. Sua popularidade atraía muita gente e a aglomeração de seguidores preocupava as autoridades, que inclusive mandaram prendê-lo. A mesma popularidade também é constatada em várias cidades do Paraná e do Mato Grosso.

O monge João Maria de Jesus, além de certa semelhança física, tinha muitas outras semelhanças com o primeiro monge, João Maria de Agostinho, como o hábito de fixar cruzes pelo caminho, a indicação de fontes de águas sagradas e o constante peregrinar. $\mathrm{O}$ segundo era tratado como São João Maria, pelos seus supostos poderes milagrosos e pelas curas que seus devotos lhe atribuíam.

No imaginário popular, João Maria teria voltado depois de sua morte na pessoa de outros monges peregrinos que percorreram a região. Na crença popular, ele sequer teria morrido. Welter (2007) faz referência à hipótese da superposição identitária dos monges conhecidos como João Maria, que percorriam a região. Esses diversos peregrinos reconhecidos como sendo o monge João Maria possuíam traços comuns: são pessoas que não se enquadram na estrutura social vigente e 
até representam sua negação; receberam, em sonho, a missão de peregrinar pelo mundo penitenciando-se e pregando; têm origem e morte incertas; possuem qualidades de mediadores por excelência do mundo do sagrado; são peregrinos, sem lar, sem família e sem residência; penitentes, pregam o apocalipse como castigo divino e busca de um sentido para um mundo sem sentido; possuem um poder milagroso de cura e o poder da imortalidade, uma vez que alcançaram a perfeição da condição humana aqui na Terra. (MOURÃO, 1975).

Welter (2007) chega a considerar os dois monges João Maria como um único sujeito, tido pela população como monge peregrino, monge santo, mago prodigioso, profeta, homem simples entre os sertanejos, que pregava e praticava o bem, orava, aconselhava, batizava, receitava remédios, predizia fatos terríveis, profetizava o fim do mundo, pregava penitências, fornecia uma esperança aos sertanejos, orientava sobre a vida cotidiana. Dessa forma, João Maria é um nome que não só aglutina os diversos monges, mas expressa a unidade dos sentimentos, expectativas e esperanças de mudança social das populações que participaram dessas guerras, no início do século XX, e daquelas que hoje ainda o têm como referência no seu universo simbólico. Para o povo caboclo, os monges encarnavam o protesto e os anseios do povo simples e explorado dos sertões, não representavam o status quo, nem as instituições oficiais ou os dominantes e, portanto, significavam esperança de transformação. Para Cabral (1960), "no sertão, no planalto, nos vales e nas coxilhas São João Maria foi um só”.

O último monge, José Maria, pregava contra a República e anunciava grandes calamidades numa terra de ninguém, que fora disputada pela Argentina e pelo Brasil e depois pelos Estados de Santa Catarina e Paraná. Para as autoridades, a morte do monge José Maria na batalha do Irani significava também o fim do movimento caboclo na região. Na realidade, porém, a morte de José Maria, combatendo para proteger os sertanejos, transformou-se num "encantamento", do qual ele deveria voltar. A identificação dos sertanejos com João Maria aumenta, fato que revigora o movimento místico na região. Processa-se a transfiguração de José Maria em santo. Em suas profecias, os monges 
falavam o que a população queria ouvir. O profeta é visto como um intérprete de seu tempo.

\section{REFERÊNCIAS}

CABRAL, Oswaldo Rodrigues. João Maria: interpretação da campanha do Contestado. São Paulo: Nacional, 1960.

FACHEL, José F. Monge João Maria: Recusa dos Excluídos. Porto Alegre: UFRGS, 1995.

KARSBURG, Alexandre de Oliveira. O eremita do novo mundo: a odisseia de um monge peregrino na América católica do século XIX. In: VALENTINI, D. J.; ESPIG, M. J.; MACHADO, P. P. (Org.). Nem fanáticos, nem jagunços: reflexões sobre o Contestado (1912-2012). Pelotas: UFPel, p. 85-107.

MACHADO, Paulo P. Um Estudo Sobre as Origens Sociais e a Formação Política das Lideranças Sertanejas do Contestado, 1912-1916. (Tese de doutorado) Campinas: Unicamp/História, 2001.

MARQUETTI, Délcio; LOPES DA SILVA, Juraci B. Religiosidade e religião no oeste de Santa Catarina: a crença no monge João Maria e a instituição do Catolicismo. Revista de Humanidades, 11(29), jan./jul. 2011, Natal,UFRN. WELTER, Tânia. O Profeta São João Maria continua encantando no meio do povo: um estudo sobre os discursos contemporâneos a respeito de João Maria em Santa Catarina (Tese de Doutorado). Florianópolis: UFSC, 2007. 


\section{Museu Fritz Plaumann}

O Museu Entomológico Fritz Plaumann está situado no distrito de Nova Teutônia, interior do município de Seara, em Santa Catarina. Foi criado pelo entomólogo alemão Fritz Plaumann, ao longo de quase todo o século XX. Seu acervo é o resultado de aproximadamente 70 anos de trabalho de coleta e classificação de insetos da fauna local, especialmente da área de floresta do Oeste catarinense, embora inclua exemplares da floresta atlântica dos três Estados sulinos, de São Paulo e mesmo da floresta amazônica (SILVA, 1998). A coleção de insetos do museu tem em torno de 73.000 exemplares, de 9.601 espécies, representando 19 ordens de espécies, 328 famílias e 2.219 gêneros. Cerca de 1.500 dessas espécies, antes desconhecidas da ciência, foram descobertas por Plaumann. Muitas delas não mais existem na natureza. Seu trabalho foi reconhecido no mundo inteiro e ele se tornou um renomado cientista mundial. Cerca de 150 das novas espécies descobertas por ele foram batizadas com o seu próprio nome. Em 1985, Plaumann obteve a Medalha do Mérito Universitário da Universidade Federal de Santa Catarina e, em 1991, recebeu a Grã-Cruz do Mérito Científico, a mais alta condecoração do campo da ciência da Alemanha. O Museu Fritz Plaumann é o maior museu entomológico da América Latina, que atualmente pertence à Prefeitura Municipal de Seara.

Fritz Plaumann nasceu em Eylau, na Prússia Oriental, onde hoje é a Lituânia, em 02 de abril de 1902 e morreu em 1994, aos 92 anos. Chegou ao Brasil com seus pais, Friederich e Hulde, em 1924, quando tinha 22 anos e se instalou próximo ao distrito de Nova Teutônia, no município de Seara. A viagem de navio partiu da Alemanha, em $1^{\circ}$ de outubro de 1924 e terminou no Porto de Rio Grande, algumas semanas depois. De Rio Grande, a família foi de trem até Santa Maria e, depois, até a cidade de Itá, em Santa Catarina, seguindo de carroça até a vila de Nova Teutônia, onde a família fixou residência. No início, Fritz trabalhou como agricultor, fotógrafo e comerciante. Depois, foi professor de alemão e português na escola da comunidade local. Fritz casou com a alemã Clarissa Links, em 1954. Eles não tiveram filhos 
e adotaram Gisela Germandorf como filha. Mas como muitos outros imigrantes da época, Clarissa não resistiu viver muito tempo naquelas condições e, em 1966, decidiu voltar para a Alemanha. Em 1972, Fritz assumiu a tutela da jovem Edeltraud Gomman, que se tornou, depois, sua principal ajudante no preparo dos insetos para a sua classificação. Sua mãe morreu em 1924 e seu pai, em 1928.

Logo após sua chegada ao Brasil, em $1^{\circ}$ de janeiro de 1925, Fritz inicia suas pesquisas na região, como declara em seu diário: "O dia primeiro de janeiro de 1925 foi um dos mais importantes da minha vida. Nesse dia foi lançada por mim, metaforicamente, a pedra fundamental para todas as minhas pesquisas aqui no Brasil" (SPESSATO, 2001). Aquela era, sem dúvida, uma atitude muito ambiciosa, se considerarmos a grandiosidade da obra que estava de fato iniciando, em condições precárias e o desconhecimento quase completo que tinha da região. Suas pesquisas iniciadas naquele ano de 1925 só terminam com sua morte, em 1994.

Fritz Plaumann, mesmo vivendo grande parte do tempo na floresta caçando insetos, esteve muito integrado com a comunidade de Nova Teutônia. Desde os primeiros anos procura integrar-se na vida daquela pequena comunidade, participando de seus principais eventos e auxiliando as famílias em casos de enfermidades. Muitas vezes, era chamado, até para a realização de cerimônias fúnebres. Em 1926, decorridos menos de dois anos de sua chegada, participa da construção de uma escola, da qual se torna o primeiro professor, conforme ele próprio narra em seu diário: “Domingo, 17/07/1927. Na assembleia de nossa comunidade fui eleito, com nove votos contra um, para professor da escola particular de Nova Teutônia, para ensinar nas línguas alemã e portuguesa" (SPESSATO, 2001). No mesmo diário, narra sua emoção ao terminar aquela gratificante experiência, que durou até 1932: "Porém, no fim, quando acompanhava com o violino o canto dos alunos pela última vez e a despedida, isso não passou sem emoção. Sempre tinha me dado muito bem com os alunos, não havia ninguém que me aborrecesse de propósito." (SPESSATO, 2001).

Ao pisar aquele solo do Oeste catarinense, Fritz mostra-se deslumbrado com a grande biodiversidade que encontrou no local. Sua 
curiosidade científica, no entanto, não nasceu naquele momento, pois vinha sendo alimentada desde sua infância pelo seu pai, que lhe comprava livros sobre astronomia, botânica, zoologia e outras áreas do conhecimento. Por esse motivo, ele conta que seus colegas o apelidaram de "pesquisador", ainda durante seus estudos básicos na Alemanha. E ele se tornou, de fato, um grande e renomado pesquisador. Sempre foi metódico e meticuloso. Desde os primeiros dias, depois de sua chegada ao Brasil, começou a fazer anotações em seus cadernos sobre a meteorologia, a direção dos ventos e as precipitações pluviométricas, mas especialmente sobre a fauna e a flora da região do Alto Uruguai Catarinense. Em sua coleção, encontram-se insetos coletados desde o início de seus trabalhos, na década de 1930, até o final de sua vida.

No entanto, o desenvolvimento de suas pesquisas não dependia apenas do seu trabalho de coleta e classificação dos insetos, mas também dos inúmeros contatos que mantinha com cientistas e instituições nacionais e estrangeiras. Além das cartas que escrevia, Plaumann enviava exemplares de insetos através do posto dos correios da comunidade de Itá, localidade mais próxima de sua residência (LUBENOW, 2013). Os primeiros contatos com instituições brasileiras foram feitos com cientistas do Jardim Botânico do Rio de Janeiro e do Instituto Butantã de São Paulo. Com este último, inicia ainda no ano de 1927, os contatos para o recebimento de soro contra a mordida de cobras e de aparelhos para capturá-las e enviá-las para os laboratórios do Instituto, em São Paulo. Seus contatos com pesquisadores estrangeiros também não se fizeram esperar. Ainda no ano 1933, anotava em seu diário: "Já recebia de especialistas as primeiras identificações. O especialista da família Gyrinidae, senhor Ochs, escrevia-me contando que encontrara uma nova, em homenagem ao coletor: "Gyretes plaumanni”. (SPESSATO, 2001). No ano de 1934, Fritz começou a corresponder-se com o entomologista alemão, Ferdinand Nevermann e com o Dr. O. Lundblad, diretor da Naturhistoriska Riksmuseum de Estocolmo, que analisou mais de uma centena de espécies novas colecionadas por Fritz Plaumann. Esse intercâmbio com aproximadamente 40 cientistas do mundo inteiro manteve-se praticamente até sua morte, em 1994. Paul Anaud Jr, curador e presidente da Californian Academy 
of Sciences, com quem Friz Plaumann se correspondia, declarou que Fritz Plaumann foi o maior descobridor e colecionador de insetos da América Latina, no século XX. Suas correspondências foram interrompidas apenas durante a Segunda Guerra Mundial. Grande parte de suas pesquisas são relatadas em seu alentado livro de 379 páginas, publicado em alemão, em 1947, com o sugestivo título "Die Enstehung des Lebens", que significa "A formação da vida".

\section{REFERÊNCIAS}

LUBENOW, Aline M. Fritz Plaumann: um entomólogo em construção no sertão catarinense (1924-1945). XXVII Simpósio Nacional de História Natal, julho de 2013.

MUSEU FRITZ PLAUMANN. Disponível em: <www.

museufritzplaumann.ufsc.br>.

SILVA, Rogério R. da. A coleção entomológica do Museu Fritz Plaumann.

Biotemas, 11 (2), 1998.

SPESSATTO, Mary Bortolanza. (Org.). O diário de Fritz Plaumann.

Chapecó: Argos, 2001 


\section{Povos indígenas}

Ao longo de sua história, o território do Oeste catarinense sempre esteve marcado por múltiplas dimensões culturais, que resultaram dos conflitos e da convivência de grupos sociais, como os povos indígenas, caboclos, colonos e quilombolas, que ali conviveram e ainda hoje disputam a terra como meio básico de sobrevivência. Muitos desses conflitos continuam vivos, especialmente o relacionado com a demarcação das terras indígenas (D’ANGELIS, 2006).

Os povos indígenas, que há muitos séculos habitaram o território do Oeste catarinense, pertenciam a dois grupos linguísticos, o grupo Jê e o grupo Tupi. Ao primeiro grupo pertenciam os índios Kaingang e os Xokleng, preponderantes na região. Já os índios Guarani pertenciam ao grupo linguístico Tupi.

De acordo com pesquisas arqueológicas recentes, o processo de povoamento indígena do território do Oeste catarinense pode ser dividido em três fases. Numa primeira fase, ocorrida há cerca de $12 \mathrm{mil}$ anos, teriam aportado à região povos caçadores e coletores nômades. Depois, por volta de 2.500 anos, teriam chegado os povos de língua Jê, provavelmente vindos de regiões centrais do Brasil. Finalmente, a última fase migratória, formada pelos povos tupi-guaranis, oriundos da Bacia Amazônica, teria chegado por volta de 2 mil anos atrás. Essas informações desmentem o argumento propalado pelos colonizadores antigos e modernos de que encontraram um território "vazio" ou um "deserto", pois este território já estava fortemente ocupado de longa data. A historiografia tradicional, de modo geral, colocou as populações indígenas na condição de invisíveis, por não contemplá-los em seus estudos ou por fazê-lo de forma marginal, em geral vendo-os como parte da natureza a ser dominada e conquistada. Na região, assim como na América, a conquista do território já ocupado pelos povos indígenas significou um verdadeiro genocídio, uma vez que eles foram praticamente dizimados pelas guerras, epidemias trazidas pelos colonizadores, como a gripe e varíola, e mesmo pela escravização. 
As primeiras expedições de reconhecimento e conquista dos territórios indígenas do Oeste catarinense começam a chegar ainda no século XVI. A primeira delas teria sido chefiada pelo conquistador espanhol D. Álvar Nuñes Cabeza de Vaca, governador geral do vice-reinado espanhol da região do Prata, que partiu da Ilha de Santa Catarina, entre 1541 e 1542, atravessou o território até chegar a Assunção. Poucos anos depois, entre 1552 e 1553, foi o militar alemão Ulrich Schmidel, que teria atravessado o Peperi-Guaçu e chegado à margem direita do Rio Uruguai, aproximadamente na região atual de Palmitos. Nos séculos XVII e XVIII, chegaram os jesuítas vindo do Paraguai e, em seguida, os bandeirantes vindos de São Paulo. Eles atacaram as reduções jesuíticas e levaram mais de 60 mil indígenas escravizados para São Paulo. No início do século XIX vieram os fazendeiros para ocupar os campos de Guarapuava e de Palmas, visando à criação de gado. A ocupação desses campos, que na sua maior parte representa o atual território do Oeste catarinense, era tida como vital para a geopolítica do Império, em face às disputas territoriais com a Argentina.

Os povos indígenas que habitavam a região eram preponderantemente os Kaigangs e Xoklengs, pertencentes ao grupo Jê. A relação dos invasores com os diversos povos indígenas era uma relação entre colonizador e colonizado e implicava uma situação de exploração contínua, nem sempre facilmente perceptível, desde o passado até o presente, mas que implicou a expropriação de suas terras, de suas vidas e de sua cultura. As reações dos povos indígenas aos invasores foram diferenciadas, envolvendo desde certa convivência, como a dos Guaranis e relações ambíguas de aceitação e beligerância como foi o caso dos Kaingangs, liderados pelo cacique Condá e Xoklengs (MALAGE, 2010). Na realidade, não restavam muitas alternativas aos povos indígenas frente aos invasores de suas terras, pois representavam a parte mais fraca e vulnerável nessa relação. Podiam aceitar a ocupação e integrar-se à forma de vida dos colonizadores, aldeando-se em vilas, o que lhes garantia alguma condição de sobrevivência, fugir de suas terras, abandonando tudo o que possuíam, ou resistir e serem escravizados ou simplesmente eliminados, como acabou acontecendo com a maior parte da população indígena. 
Por sua vez, as políticas oficiais em relação aos povos indígenas evoluíram desde a defesa da integração na sociedade brasileira, do que sobrou desses povos, após a ocupação de suas terras, até uma política de aldeamento e demarcação de terras indígenas, o que em princípio daria mais condições de sobrevivência e preservação de sua cultura e do seu modo de vida.

No entanto, o contato com os homens brancos, seu modo de vida e seus valores, resultou em um processo de desintegração econômica, social e cultural dos povos indígenas, desarticulando o seu sistema de vida tribal e comunitário, contaminando o grupo com doenças até então desconhecidas, sem que os indígenas oferecessem qualquer resistência biológica.

Atualmente existem diversas reservas indígenas no Oeste catarinense, destacando-se a Condá, em Chapecó, o Toldo Imbu, em Abelardo Luz, o Toldo Chimbangue, em Chapecó, o Xapeco, em Ipuaçu e Entre Rios e Toldo Pinhal, em Seara. Essas reservas são essencialmente de indígenas da tribo Kaingang. Já os indígenas da tribo Guaraní ocupam outras reservas semelhantes na região.

\section{REFERÊNCIAS}

BRIGHENTI, Clovis Antonio. Povos indígenas em Santa Catarina. Disponível em:

$<$ https://leiaufsc.files.wordpress.com/2013/08/povos-indc3adgenas-emsanta-catarina.pdf $>$. Acesso em: 3 abr. 2017.

D’ANGELIS, Wilmar da Rocha. Para uma história dos índios do oeste catarinense. Chapecó, Cadernos do CEOM, Ano 19, n. 23, 2006 - CEOM: 20 anos de memórias e histórias no Oeste de Santa Catarina.

MALAGE, Kátia Graciela J. M. Condá e Viri: chefias indígenas em PalmasPR, década de 1840. (Dissertação de Mestrado). Curitiba: UFPR, 2010. 


\section{Oeste catarinense}

Uma região não é algo natural, mas uma construção humana, um espaço permeado de relações sociais. Nessa perspectiva, uma região define-se e diferencia-se de outras, por uma série de fatores característicos que envolvem sua configuração histórico-geográfica, territorial, demográfica, cultural, socioeconômica e político-administrativa. É por partilhar de forma diferenciada e específica algumas dessas características que o Oeste catarinense se define como uma região.

A formação histórica da Região Oeste de Santa Catarina reporta-se aos povos indígenas, que há muitos séculos habitavam a região. Seus representantes mais recentes são as tribos Xokleng e principalmente a Kaingang. Esses povos dominaram a região até meados do século XIX, quando passou a ser disputada também por outras populações, notadamente tropeiros e caboclos. Os primeiros conquistadores foram os paulistas que, percorrendo o "Caminho das Tropas", tropeavam o gado dos campos do Sul para o centro comercial de Sorocaba. Posteriormente foram abertos novos caminhos para o Sul, ao longo dos quais se formaram pousos, currais, vilas e fazendas de gado, nos campos do Oeste. No início do Século XX, a Estrada de Ferro São Paulo - Rio Grande do Sul (EFSP-RG), passando pelas terras contestadas, à margem dos rios do Peixe, Uruguai e Passo Fundo, estabeleceu um novo marco na ocupação da região.

Do ponto de vista territorial, a construção da região Oeste catarinense passou por diversas disputas de fronteiras e configurações espaciais (RENÊ, 2004). Inicialmente, entre Portugal e Espanha, depois entre Brasil e Argentina, a Questão de Palmas e, finalmente, a disputa entre Paraná e Santa Catarina, um dos motivos da Guerra do Contestado (1912-1916), quando se definiu que o referido território pertencia ao estado de Santa Catarina. No entanto, para manter o território conquistado do Paraná era preciso "povoá-lo", para tanto, investiu-se num intenso processo de colonização (PAIM, 2006).

Em termos geográficos, esta região corresponde a Mesorregião do Oeste Catarinense, uma das seis que compõem o Estado de Santa 
Catarina. É formada por cinco microrregiões: Chapecó, Concórdia, Joaçaba, São Miguel do Oeste e Xanxerê. Ao todo abrange 118 municípios, que fazem fronteira com as Mesorregiões Norte e Serrana de SC, com os estados do Paraná e Rio Grande do Sul e com a República Argentina. No entanto, além dos aspectos geográficos e territoriais, esta Região se define e se diferencia de outras por suas peculiaridades históricas, socioeconômicas e político-administrativas.

A formação econômica da Região Oeste compreende diversas fases e ciclos, que incluem a ocupação dos campos, com as grandes fazendas de criação pecuária, a ocupação das matas para a extração da erva-mate, a atividade madeireira, o processo de colonização e a agricultura familiar e, finalmente, a formação e o desenvolvimento dos complexos frigoríficos e agroindustriais. Os ciclos da pecuária, da erva-mate e o da madeira tiveram uma importância econômica reduzida, pouco contribuindo para a formação do capital e o desenvolvimento econômico regional. Este só veio a receber um impulso decisivo com o processo de colonização da região, pois foi a partir da agricultura familiar de subsistência, especialmente através da criação de suínos que veio dar início a acumulação de capital. A criação de suínos, por sua vez, deu origem à poderosa agroindústria frigorífica da região. A característica principal da formação agroindustrial consiste na peculiar articulação que se estabeleceu entre as indústrias frigoríficas e a agricultura familiar, tornando-se a base econômica regional desde o período da colonização, nas décadas de 1920 a 1940.

A formação social desta região caracteriza-se pela constituição das sociedades que ali se estruturaram, a partir tanto das relações de propriedade e de trabalho, como das relações étnico-culturais entre os povos que habitaram a região. Via de regra, mas não exclusivamente, a formação social de uma região costuma acompanhar sua formação econômica, que lhe serve de base, embora não possa ser explicada unicamente pelos fatores de ordem econômica, pois sofre influência decisiva de outros fatores de ordem cultural, religiosa, política e mesmo simbólica. No caso da Região Oeste Catarinense, sua formação social constituiu-se pela evolução de quatro fases sucessivas e superpostas ao mesmo tempo: a formação social nativa, formada pelas sociedades 
indígenas, a formação social cabocla, a formação social colonial e a formação social capitalista.

Num segundo momento, temos a mescla da sociedade primitiva e cabocla, num período que vai desde as primeiras ocupações do território oestino até aproximadamente 1930, quando se intensifica o processo de colonização propriamente dito, com colonos de origem europeia, italianos, alemães e poloneses, procedentes do Rio Grande do Sul. O processo de colonização trouxe grandes transformações para a Região Oeste catarinense, não apenas em relação à ocupação e ao povoamento do território, mas também no tocante às relações sociais que se desenvolveram nas novas colônias, alterando modo de vida, lazer, trabalho, uso da terra e o cotidiano cultural dos colonos. Foi a partir do longo processo de colonização que se constituiu a terceira fase desta formação social regional, a "formação social colonial", a qual mescla traços da formação social anterior com traços de uma sociedade familiar capitalista. Uma quarta e última fase pode ser denominada "formação social capitalista", a qual se constitui ao mesmo tempo em que se forma e desenvolve o complexo frigorífico e agroindustrial.

A atual identidade regional do Oeste catarinense começa a definir-se com mais força a partir das importantes medidas de caráter político-administrativas tomadas nas primeiras décadas do século XX, através das quais o território regional foi dividido em duas grandes áreas administrativas, ambas emancipadas em 25 de agosto de 1917, o município de Cruzeiro, atual Joaçaba, no Meio Oeste, e o de Chapecó, que abrangia uma extensa área de aproximadamente 14 mil $\mathrm{km}^{2}$ e se estendia até a fronteira argentina. Tais medidas foram fundamentais para o fortalecimento da atual identidade regional e sua integração com o restante do território estadual, bem como para iniciar um processo de desenvolvimento socioeconômico regional.

\section{REFERÊNCIAS}

CEOM - Centro de Memória do Oeste Catarinense (Org.). Para uma história do Oeste Catarinense: 10 anos de CEOM. Chapecó: UNOESC, 1995. 
OLIVEIRA, Antônio Marcos P. A dinâmica do desenvolvimento regional. (Dissertação de Mestrado). Universidade Municipal de São Caetano do Sul, 2010.

PAIM, Elison Antonio. Aspectos da constituição histórica da Região Oeste de Santa Catarina. Saeculum. Revista de História. [14]; João Pessoa: jan./ jun. 2006.

RENK, Arlene. A Colonização do oeste catarinense: as representações dos brasileiros. CEOM - Centro de Memória do Oeste Catarinense (Org.).

Para uma história do Oeste Catarinense: 10 anos de CEOM. Chapecó: UNOESC, 1995.

Identidade comunitária. Chapecó: Argos, 2004. 


\section{Questão interestadual de}

limites: SC-PR

A questão de limites territoriais entre os estados de Santa Catarina e do Paraná tem seu início com o desmembramento da Comarca do Paraná em relação à Província de São Paulo, em 1853 (VOLTOLINI, 2009). A disputa entre as províncias de São Paulo e Santa Catarina pelas terras contestadas vem desde o período colonial. A província do Paraná, ao ser criada em 1853, herdou esta ambígua e nebulosa delimitação de fronteiras, próxima aos Campos de Palmas. O Paraná, ao desmembrar-se de São Paulo, pretendia todo o território que hoje é o Oeste de Santa Catarina. A pretensão catarinense tinha por base dois documentos: o Ato de criação do Governo Militar de Santa Catarina, em 1733, que separava a capitania do estado em relação à província de SP, subordinando-a diretamente ao vice-rei do Rio de Janeiro. Esse documento fixava como limite de Santa Catarina, ao norte, os rios Negro e Iguaçu; a Carta Régia, de 1749, também estabelecia os rios Negro e Iguaçu como limites, ao norte. Até o início do século XIX, a Capitania de Santa Catarina restringia-se à ilha e a pequenas vilas litorâneas, mas a partir de 1820, com o desmembramento de Lages da província de São Paulo e sua incorporação a Santa Catarina, a questão dos limites entre as províncias se acentuou, pois Santa Catarina insistia na antiga demarcação colonial, enquanto paulistas e paranaenses ocupavam as terras do Oeste, que antes não pertenciam à comarca de Lages. $\mathrm{O}$ Paraná defendia seu direito à posse dessas terras valendo-se do princípio uti possidetis, que confere a posse a quem usa a terra. Enquanto isso, o governo imperial defendia que a jurisdição sobre os territórios em litígio deveria ser resolvida através de lei acordada entre as assembleias das duas províncias. A situação provisória dos limites favorecia o Paraná. Enquanto a situação não se resolvia, as duas províncias desenvolveram intensa atividade de ocupação e povoamento do sertão com fazendas e lavouras. 
Durante o período imperial, a discussão sobre o litígio pouco avançou, mas se tornou mais aguda com a proclamação da República, quando a nova constituição passa a assegurar às províncias o direito ao recolhimento de impostos e a gestão das terras chamadas devolutas. Em 22 de maio 1896, representantes dos dois estados reúnem-se na Capital federal e acordam, através de lei, que os limites em questão deviam ser decididos através de arbitramento. Entretanto, em outubro do mesmo ano, a lei foi revogada, pois o Supremo Tribunal Federal não aceitou as assinaturas dos advogados dos estados. Nos anos seguintes as decisões continuavam sendo proteladas. O Supremo Tribunal Federal assume a responsabilidade pela questão, entretanto não dá um veredito. Enquanto a questão não se resolve, os estados se valem da força militar para ampliar seu controle sobre as áreas em disputa. Finalmente, em seis de junho de 1904, o Superior Tribunal de Justiça dá ganho de causa ao Estado de Santa Catarina. Essa decisão volta a acirrar os ânimos. O Paraná recorre da decisão judicial e a questão volta a ser analisada pelo Superior Tribunal de Justiça. Em dezembro de 1909, o Tribunal rejeita os recursos do Paraná, que contrata Ruy Barbosa para defender sua posição e volta a entrar com novos recursos, os quais são novamente recusados, em 1910. O Tribunal confirma as duas sentenças anteriores, fixando a divisa entre os dois estados através dos rios Negro e Iguaçu. Em 1913, porém, a sentença ainda não havia sido executada. O Paraná contestou novamente e passou a defender uma arbitragem independente ou um acordo direto entre as partes, mas Santa Catarina insistia na execução da sentença judicial. No entanto, não tinha força política suficiente para fazer executar a sentença que lhe era favorável (MACHADO, 2001).

Para complicar mais a situação, as forças políticas de Santa Catarina se dividem. $\mathrm{O}$ ministro Lauro Muller aderiu em parte à posição paranaense, talvez visando consolidar sua posição de liderança nacional, mas o governador Vidal Ramos se opôs resolutamente a esta posição. Em 24 de junho de 1915, entretanto, o Presidente da República, Wenceslau Braz Pereira Gomes, reuniu os governadores dos dois estados com o propósito de resolver a questão de limites através de um acordo, mas Santa Catarina se mostrava irredutível em defesa do cumprimento da decisão judicial. A tentativa de acordo do Presidente da República 
fracassa. Em 10 de abril de 1916, ele volta a propor um acordo pelo qual os limites de Santa Catarina, ao norte, ficariam sendo o rio Negro e o Iguaçu abaixo até o primeiro ribeirão nas proximidades de União da Victória, como ficara estabelecido nas sentenças judiciais e as terras ao Oeste até a fronteira Argentina seriam dividias da seguinte forma: dos 48 mil quilômetros quadrados em litígio, o Paraná ficaria com 20 mil e Santa Catarina com 28 mil. O litígio de mais de meio século chegava ao fim. Era 20 de outubro de 1916. Para chegar a esse acordo, contribuíram o desgaste provocado pela guerra do Contestado e o esforço pessoal do Presidente Wenceslau Brás.

A questão dos limites, embora tenha começado mais de meio século antes da Guerra do Contestado, terminou no mesmo ano, mas não existe relação direta de causa e efeito da primeira sobre a segunda (MACHADO, 2001). No entanto, a longa disputa dos limites deixou suas marcas sobre a natureza da ocupação demográfica e sobre o perfil social e políticos de seus habitantes. Também não é exagerado afirmar que, em algumas regiões, a questão dos limites foi decisiva para a adesão de comunidades ao movimento caboclo e sua solução também foi decisiva para evitar o seu ressurgimento.

\section{REFERENCIAS}

MACHADO, Paulo P. Um Estudo Sobre as Origens Sociais e a Formação Política das Lideranças Sertanejas do Contestado, 1912-1916. (Tese de doutorado) Campinas: Unicamp/História, 2001.

NEUNDORF, Alexandro. A questão de limites entre Santa Catarina e Paraná e a construção identitária paranaense: as fronteiras, o outro e o projeto intelectual. Revista Eletrônica Cadernos de História: publicação do corpo discente do departamento de história da Universidade Federal de Ouro Preto, Ano II, n. 01, março/2007.

VOLTOLINI, Anderson F. F. A questão de limites de terras entre Santa Catarina e Paraná: uma análise das mensagens de governadores de 1900 a 1916. Revista Santa Catarina em História, Florianópolis, UFSC, v.1, n.2, 2009. 


\section{Questão de Palmas}

A Questão de Palmas foi um contencioso fronteiriço entre Brasil e Argentina, ocorrido no final do século XIX. Estava em disputa um território de $30.621 \mathrm{~km}^{2}$ envolvendo, do lado brasileiro, a região Oeste dos estados de Santa Catarina e do Paraná e do lado argentino, a Província de Misiones. Embora as divergências em torno dessa fronteira sejam uma herança que remonta ao período colonial, elas se acentuam, quando a Argentina passa a reivindicar como seu aquele território, com base nos Tratados de Madrid, de 1750, e de Santo Ildefonso, de 1777, que estabeleciam as fronteiras entre Portugal e Espanha. A Questão de Palmas, para os brasileiros, e Question de Misiones, para os argentinos, só veio a ser resolvida através do arbitramento internacional conduzido pelo Presidente dos Estados Unidos, Grover Cleveland, em 1895.

A origem da controvérsia reside no fato de que as fronteiras entre os dois países estabelecidas nos referidos tratados nunca foram efetivamente demarcadas in loco, abrindo, assim, a possibilidade de diferentes interpretações dos acidentes geográficos, como de fato veio a ocorrer. $\mathrm{O}$ Tratado de Madrid foi o primeiro acordo entre Espanha e Portugal sobre os limites respectivos na América do Sul, mas foi o Tratado de Santo Ildefonso que estabeleceu a fronteira entre os dois países na região, no sentido norte-sul, como sendo os rios Peperi-Guaçu e Santo Antônio, mas as comissões demarcadoras, criadas por Portugal e Espanha, nunca chegaram a definir exatamente quais eram esses rios, de modo a evitar futuros litígios de demarcação. A questão agravou-se quando, em 1881, a Argentina entendeu que o rio Peperi-Guaçu do Tratado de 1777 era o atual rio Chapecó, afluente do rio Uruguai e que o rio Santo Antônio, nomeado no mesmo Tratado, era o atual rio Chopim, afluente do rio Iguaçu. Em 1888, uma nova interpretação foi feita pela Argentina, que passou a reivindicar o rio Jangada (também afluente do Iguaçu), como sendo rio Santo Antônio, do Tratado de Santo Ildefonso. A iniciativa unilateral da Argentina ultrapassava os limites fronteiriços anteriores demarcados pelo Tratado de Madri e, com mais precisão, pelo de Santo 
Ildefonso, os quais haviam sido aprovados pelo Congresso da Argentina, em 1857, embora não ratificados pelo governo argentino. Para o Brasil, no entanto, a fronteira entre os dois países devia ser a dos rios Peperi-Guaçu e Santo Antônio, conforme estabelecia o Tratado de Santo Ildefonso. A pretensão argentina acirrou os ânimos e aumentou a tensão na região, pois nenhum dos dois países manifestava disposição de abrir mão daquelas terras. A posição brasileira parecia mais sólida, uma vez que a área contestada, além das populações indígenas, há décadas era habitada quase exclusivamente por brasileiros, não havendo presença de argentinos. Uma vez instalado o litígio, tanto o Brasil como a Argentina fortaleceram suas posições de ambos os lados da fronteira. A Argentina, através da província de Misiones; o Brasil, através das colônias militares de Chapecó e Chopim.

Uma primeira tentativa de acordo ocorreu, em 7 de setembro de 1889, através de um Tratado de Arbitramento, pelo qual o litígio seria resolvido através de arbitragem internacional. No entanto, após a Proclamação da República, em 25 de janeiro de 1890, o Presidente Marechal Deodoro da Fonseca, preocupado com as questões de segurança internas, manifestou disposição em resolver rapidamente a questão dos limites com a Argentina e propôs dividir o território contestado entre os dois países. O acerto foi estabelecido no Acordo de Montevidéu, assinado pelo Ministro das Relações Exteriores do Governo Provisório, Quintino Bacaiuva, mas o Congresso Nacional brasileiro rechaçou esse acordo e reafirmou a vigência do que fora estabelecido no Tratado de Arbitramento.

A Questão de Palmas foi, então, submetida ao presidente dos Estados Unidos, como estabelecia o Tratado de Arbitramento de 1889. Pelo lado do Brasil, atuou inicialmente o barão Aguiar de Andrade, que veio a falecer ainda no desenrolar das negociações. A partir de 1893, coube a José Maria da Silva Paranhos Júnior, barão do Rio Branco, chefiar a delegação brasileira. A delegação argentina foi chefiada por Estanislao Severo Zeballos.

O barão do Rio Branco estava assessorado por uma equipe preparada, da qual fazia parte o general Dionísio Cerqueira. Valendo-se dos seus estudos de história e geografia e da experiência adquirida 
com seu pai, o visconde de Rio Branco, em negociações internacionais anteriores, o barão do Rio Branco valeu-se de um amplo trabalho de reconstituição histórica, geográfica e jurídica, com grande número de mapas e documentos. Apresentou, inclusive, o Mapa das Cortes, de 1749, encontrado no Depósito Geográfico do Ministério dos Negócios Estrangeiros da França, onde se estabelecia com toda a clareza a localização dos rios Peperi-Guaçu e Santo Antônio, que não podiam ser confundidos com os rios Chapecó e Jangada, como pretendia a Argentina. A exposição de Rio Branco representou um verdadeiro tratado geopolítico da região.

Além da farta documentação histórica e geográfica, um dos principais argumentos usados por Rio Branco foi o princípio uti possidetis, segundo o qual tem direito à posse da terra quem a usa. E, no caso em questão, na região reclamada pela Argentina, viviam 5.793 habitantes, dentre os quais 5.763 brasileiros, 30 estrangeiros e nenhum argentino. Além disso, os rios Peperi-guaçu e Santo Antônio estavam mais próximos do território brasileiro do que do argentino e, portanto, as terras do Oeste catarinense e paranaense, reivindicadas pela Argentina, eram de posse histórica de brasileiros, áreas de pecuária, com pequenos núcleos de povoamento, como Palmas do Sul, depois Clevelândia (1838), Palmas (1855), Conceição do Rosário e Campo Erê. Por essas razões, argumentava-se que o território pertencia de fato e de direito ao Brasil.

Em 6 de fevereiro de 1895, o presidente Grover Cleveland emitiu sua sentença, ratificando as pretensões brasileiras. Enquanto Rio Branco era festejado como um herói nacional, o negociador argentino era acusado de incompetente pela imprensa local. A cidade de Clevelândia, no estado do Paraná, localizada na área do litígio, teve o nome dado em homenagem ao presidente norte-americano.

\section{REFERÊNCIAS}

HEINSFELD, Adelar. Fronteira Brasil/Argentina:a questão de Palmas de Alexandre Gusmão a Rio Branco. São Paulo: Méritos, 2007.

ANNIBELLI, Mariana Baggio. Contestado: um território socioambiental. (Dissertação de Mestrado). Curitiba: PUCPR, 2009. 


\section{Território Federal do Iguaçu}

O Território Federal do Iguaçu foi criado pelo Decreto-Lei lei n.5.812, de 13 de dezembro de 1943, durante o governo de Getúlio Vargas, e extinto, em 18 de setembro de 1946, pelas disposições da Constituição Federal de 1946. O referido Território abrangia uma área de 68,8 mil $\mathrm{Km}^{2}$, em terras do Oeste e Sudoeste do Paraná e o Oeste de Santa Catarina, sendo a maior parte deles pertencente ao estado do Paraná. Ao mesmo tempo em que era criado o Território Federal do Iguaçu, foi criada, também, através do Decreto 12.417 de 1943, a Colônia Nacional General Osório, cuja sede ficava em Francisco Beltrão, com o objetivo de promover a colonização ao longo da fronteira com a Argentina, na região de Barracão. A capital do Território foi, inicialmente, a cidade de Foz do Iguaçu, mas logo após a instalação do novo território, por razões de segurança, foi transferida para a cidade de Laranjeiras do Sul, que ficava mais afastada da fronteira. Por conta disso, seu nome foi alterado para Iguaçu. O traçado da fronteira do Território do Iguaçu também foi alterado, em 1944, para que pudesse incorporar também a região da nova capital. $\mathrm{O}$ contexto da criação do novo território foi a denominada Marcha para o Oeste, movimento nacionalista organizado durante o Governo Vargas, que defendia a ocupação efetiva das fronteiras brasileiras de Norte a Sul do país.

No entanto, a preocupação com esta região de fronteira já existia muito antes da criação do Território do Iguaçu. No final da Guerra do Paraguai (1864-1870), a fragilidade da ocupação brasileira desta região ficou muito evidenciada, uma vez que ela sempre foi uma espécie de região abandonada, tanto pelo governo federal como pelos governos estaduais do Paraná e de Santa Catarina. O controle brasileiro efetivo da região era tênue. Havia, no entorno de Foz do Iguaçu, grandes contingentes de indígenas e de grupos estrangeiros de várias nacionalidades, mas especialmente de paraguaios e argentinos, que não falavam português. As línguas correntes eram o guarani e o espanhol. O dinheiro circulante era o peso argentino e o guarani paraguaio. 
Atividades como a navegação do rio Paraná e a exploração da madeira e do mate eram controladas por argentinos.

Depois da Guerra do Paraguai, para reforçar a presença brasileira e defender os interesses nacionais nessa região, cogitou-se em criar uma Colônia Militar, na foz do Rio Iguaçu, providência que só veio a materializar-se em novembro de 1889. Essa Colônia Militar atuou até 1910, quando foi elevada à condição de Vila e tornou-se distrito de Guarapuava. Em 14 de março de 1914, foi criado o município de Vila Iguaçu e, em 1918, finalmente recebeu a denominação atual de Foz do Iguaçu. No final da década de 1930, Getúlio Vargas já demonstrava uma preocupação especial com a questão das fronteiras do Brasil com os países vizinhos, especialmente com a região da fronteira Oeste do Paraná e de Santa Catarina. A determinação de criar territórios federais nessas áreas estava presente na Constituição de 1937, mas só veio a concretizar-se em 1943. O Decreto que criava o Território Federal do Iguaçu também criava os territórios federais do Amapá, de Rio Branco, de Guaporé e de Ponta Porã. Durante sua curta existência, o Território Federal do Iguaçu teve dois governadores militares, João Garcez do Nascimento e Frederico Trotta.

Na década de 1960, ainda no espírito da "Marcha para o Oeste", que havia motivado a criação do Território Federal do Iguaçu, voltou a ideia e o movimento na região para criar o Estado do Iguaçu, abrangendo a área do antigo território, mas a proposta não teve força para concretizar-se.

\section{REFERENCIAS}

BURILlE, Celma F. de Souza. Nas Tramas da Separação: o caso do Estado do Iguaçu nas décadas de 1960 e 1990. (Dissertação de Mestrado). Curitiba: UFPR, 2010.

LOPES, Sérgio. O Território Federal do Iguaçu no contexto da "Marcha para o Oeste". Cascavel: Edunioeste, 2002.

RITT, Evaristo. A Colônia Militar de Foz do Iguaçu: um projeto de consolidação de uma Fronteira: 1880-1920. (Dissertação de Mestrado) Londrina: UEL, 2011. 


\section{Viagem de 1929}

“A Viagem de 1929" foi realizada no período de 17 de abril e 18 de maio de 1929 pelo Presidente do Estado de Santa Catarina, Adolfo Konder, e uma comitiva de 20 pessoas, com o objetivo de efetivar o reconhecimento e a ocupação política da Região Oeste catarinense. Essa viagem durou 31 dias e percorreu cerca de três mil Km, partindo de Florianópolis, no litoral, até Dionísio Cerqueira, junto à divisa com a República Argentina. A comitiva era grande e diversificada, pois incluía, além da figura do Presidente do Estado, secretários de Estado, chefe de polícia, agrimensores, consultor jurídico e deputados. Entre eles figuravam Othon Gama D’Eça, Artur Ferreira da Costa e José Arthur Boiteux, que registraram suas impressões em importantes relatos. $\mathrm{Na}$ viagem, foram usados todos os meios de transporte disponíveis, como automóvel, lanchas, trem e até mula de carga.

Várias circunstâncias históricas justificavam aquela expedição, como a definição das fronteiras externas das terras brasileiras com a Argentina, ocorrida em 1895, a resolução dos conflitos sobre as fronteiras internas, entre os estados de Santa Catarina e do Paraná, bem como a pacificação da região, após o término da Guerra do Contestado, em 1916. Faltava, ainda, a ocupação política de parte do território, a ser feita pelo governo do Estado, ocupação a qual foi realizada de forma pouco usual, através de uma viagem de reconhecimento, que ficou conhecida como "A Viagem de 1929". Essa viagem pretendia ser uma "Marcha para o Oeste", uma tomada de posse de um espaço ainda desconhecido do poder público, que, pelo seu significado, deixou marcas profundas nos sentimentos e na imaginação popular da região. Associados ao objetivo maior da viagem, que foi a ocupação política da região por parte do governo estadual, somavam-se outros objetivos, como criar condições para o reconhecimento e a integração do território, abertura de estradas, escolas, agência postal, e implantação do telégrafo, além de impor a ordem e disciplina no Oeste, transformando uma "terra da barbárie" em uma "terra do trabalho", como foi definido por integrantes da mesma. A viagem deveria, ainda, procurar 
exercer a soberania sobre as terras do Oeste, incentivar a construção da brasilidade, preencher o vazio demográfico e apagar os últimos vestígios dos velhos rancores originados dos muitos conflitos, que dominaram a região. Tratava-se, enfim, de levar o processo civilizador para o interior do Estado.

Nas palavras de D’Eça (1992), membro da comitiva, a região era "inculta e desconhecida", mas, como uma "nova Canaã, convida, assegurando remuneradores resultados, a cooperação da inteligência e do braço do homem disposto a trabalhar". Outro membro da comitiva oficial (Costa, 1929) afirma que a Viagem visava a "implantação da ordem, o respeito às leis, ao fomento econômico, à civilização, enfim, de uma região assolada pelos movimentos revolucionários e pelo banditismo". Basta lembrar que, dois anos antes, em 1927, a Coluna Prestes havia passado pela região e o banditismo reinante no sertão, como o representado pelo conhecido "Bando de Leonel Rocha", que exterminava famílias inteiras, deixando a população muito insegura e, por isso, exigia uma ação enérgica das autoridades no combate a esse tipo de banditismo.

Por esse motivo, a viagem propiciou, também, um encontro entre Vargas e Konder, em Iraí, ocasião em que foi procedida a ratificação do "acordo policial", entre o Rio Grande do Sul e Santa Catarina, que permitia à polícia de cada Estado perseguir os ditos "bandidos", que se refugiavam no território do Estado vizinho.

A chegada da comitiva nas povoações era bem preparada e sempre recebida com festas pela população. No entanto, ao chegar à fronteira com a Argentina, na cidade de Dionísio Cerqueira, a comitiva constata que a cidade estava se desnacionalizando, pois tudo ali era argentino, os produtos consumidos eram argentinos, as crianças falavam espanhol e frequentavam escolas argentinas e, quando perguntadas pelos heróis nacionais, respondiam apontando figuras da história argentina e não heróis nacionais brasileiros. Mas, como relatam participantes da Viagem (D’EÇA, 1992; COSTA, 1929; BOITEUX, 1931), o avanço da Bandeira por esses territórios do Oeste ia deixando por onde passava as marcas da civilização, da organização administrativa 
e da ordem pública através de escolas, órgãos públicos, praças, meios de comunicação e planos de construção de rodovias.

Para muitos analistas, no entanto, a Viagem de 1929 (CEOM, 2005) teve um sentido mais simbólico do que real. Como uma nova bandeira desbravadora, representou um verdadeiro rito de conquista do território e de reconhecimento da soberania pública sobre uma região desconhecida, uma espécie de ato inaugural de sua incorporação simbólica. Uma viagem patriótica dos novos bandeirantes da brasilidade.

\section{REFERÊNCIAS}

BOITEUX, José Arthur. Oeste Catharinense. (De Florianópolis a Dionísio Cerqueira). Florianópolis: Livraria Central, 1931.

CEOM - Centro de Memória do Oeste Catarinense (Org.). A Viagem de 1929: oeste de Santa Catarina: documentos e leituras. Chapecó: Argos, 2005.

. Para uma história do Oeste Catarinense: 10 anos de CEOM.

Chapecó: UNOESC, 1995.

COSTA, A. Ferreira da. O Oeste Catharinense: visões e sugestões de um excursionista. Rio de Janeiro: Villas Boas e Cia, 1929.

D’EÇA, Othon Gama. Aos Espanhóis Confinantes. Florianópolis: UFSC, 1992. 